\title{
Excellentieonderwijs: Selectie van studenten en individuele effecten
}

Citation for published version (APA):

van Broekhoven, K., Huijts, T., Isendam, M., Jacobs, M., Kolster, R., Leest, B., Meng, C., Westerheijden, D., \& Wolbers, M. (2020). Excellentieonderwijs: Selectie van studenten en individuele effecten. ROA. ROA Reports No. 001 https://doi.org/10.26481/umarep.2020001

Document status and date:

Published: 06/04/2020

DOI:

10.26481/umarep.2020001

Document Version:

Publisher's PDF, also known as Version of record

\section{Please check the document version of this publication:}

- A submitted manuscript is the version of the article upon submission and before peer-review. There can be important differences between the submitted version and the official published version of record.

People interested in the research are advised to contact the author for the final version of the publication, or visit the DOI to the publisher's website.

- The final author version and the galley proof are versions of the publication after peer review.

- The final published version features the final layout of the paper including the volume, issue and page numbers.

Link to publication

\footnotetext{
General rights rights.

- You may freely distribute the URL identifying the publication in the public portal. please follow below link for the End User Agreement:

www.umlib.nl/taverne-license

Take down policy

If you believe that this document breaches copyright please contact us at:

repository@maastrichtuniversity.nl

providing details and we will investigate your claim.
}

Copyright and moral rights for the publications made accessible in the public portal are retained by the authors and/or other copyright owners and it is a condition of accessing publications that users recognise and abide by the legal requirements associated with these

- Users may download and print one copy of any publication from the public portal for the purpose of private study or research.

- You may not further distribute the material or use it for any profit-making activity or commercial gain

If the publication is distributed under the terms of Article $25 \mathrm{fa}$ of the Dutch Copyright Act, indicated by the "Taverne" license above, 
Maastricht University

\section{Excellentieonderwijs: Selectie van studenten en individuele effecten}

Kim van Broekhoven

Tim Huijts

Marieke Isendam

Madelon Jacobs

Renze Kolster

Bianca Leest

Christoph Meng

Maarten Wolbers

\section{ROA Rapport}

ROA-R-2020/1

Researchcentrum voor Onderwijs en Arbeidsmarkt | ROA Research Centre for Education and the Labour Market / ROA 


\section{Colofon}

(c) Researchcentrum voor Onderwijs en Arbeidsmarkt (ROA). Niets uit deze uitgave mag op enige manier worden verveelvoudigd zonder voorafgaande schriftelijke toestemming van de directeur van het ROA.

\section{Researchcentrum voor Onderwijs en Arbeidsmarkt}

Postbus 616

6200 MD Maastricht

$\mathrm{T}+31433883647$

$\mathrm{F}+31433884914$

secretary-roa-sbe@maastrichtuniversity.nl

www.roa.nl

School of Business and Economics

Maastricht University

\section{Vormgeving}

ROA secretariaat, Maastricht

ISBN: 978-90-5321-588-3

februari 2020

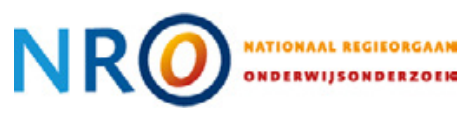

Dit project is gefinancierd door het NRO NRO projectnummer: 405-15-604

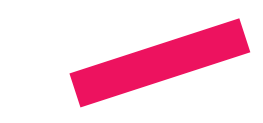

HAN_UNIVERSITY

OF APPLIED SCIENCES

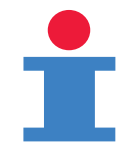

KBA Nijmegen |c|h|elp|s|

Center for

Higher Education Policy Studies 


\section{INHOUD}

Voorwoord

$1 \quad$ Inleiding

1.1 Achtergrond

1.2 Selectie van studenten

2

1.3 Effecten van excellentieprogramma's 3

1.4 Onderzoeksvragen 3

1.5 Opbouw van het rapport 4

2 Dataverzameling van onderzoek 5

2.1 Vragenlijst voor studenten van excellentieprogramma's en reguliere programma's 7

$\begin{array}{ll}2.2 \text { Studentenadministratiedata } & 14\end{array}$

2.3 Selectieoordeel en afronding excellentieprogramma 15

2.4 Interviews met selecteurs 15

2.5 Voorkeuren van selecteurs van excellentieprogramma's 16

3 Selectie van studenten in excellentieprogramma's 19

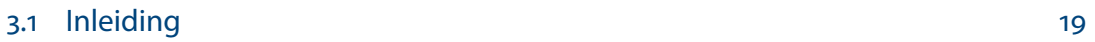

3.2 Werving - en selectieprocedures en -criteria van de deelnemende $\begin{array}{ll}\text { excellentieprogramma's } & 19\end{array}$

3.3 Effectiviteit van selectie 26

$\begin{array}{ll}3.4 \text { Voorkeuren van selecteurs van excellentieprogramma's } & 39\end{array}$

4 Effectiviteit van excellentieprogramma's 51
4.1 Inleiding
4.2 Kritisch denken 53
4.3 Creativiteit 60
$\begin{array}{ll}4.4 \text { Leiderschap } & 71\end{array}$
4.5 Politieke betrokkenheid 74
$\begin{array}{ll}4.6 \text { Studieresultaten } & 76\end{array}$
4.7 Extra analyses $\quad 84$ 
5 Conclusie en discussie $\quad 87$

$\begin{array}{ll}5.1 & \text { Inleiding } \\ 5.2 & 87\end{array}$

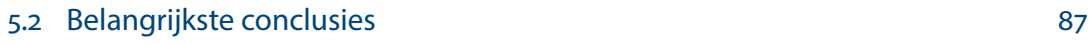

$\begin{array}{lr}5.3 \text { Beperkingen van dit onderzoek } & 89\end{array}$

$\begin{array}{ll}5.4 \text { Aanbevelingen } & 90\end{array}$

$\begin{array}{ll}\text { Literatuur } & 93\end{array}$

$\begin{array}{lr}\text { Bijlagen } & 95\end{array}$ 


\section{VOORWOORD}

In de periode van medio oktober 2015 tot december 2019 hebben wij onderzoek gedaan naar de effecten van excellentieonderwijs in het Nederlandse hoger onderwijs. Dit onderzoek was onderdeel van het onderzoeksprogramma Excellentie van het Nationaal Regieorgaan Onderwijsonderzoek. In dit rapport presenteren wij twee deelstudies van het bredere onderzoek naar excellentieonderwijs, namelijk op het gebied van (1) selectie van studenten voor excellentieonderwijs, en (2) individuele effecten van deelname aan excellentieonderwijs. De andere deelstudies binnen dit bredere onderzoek (namelijk over uitstralingseffecten van excellentieonderwijs op het reguliere onderwijs en op de reguliere organisatie, en over het werkgeversperspectief op excellentieonderwijs) worden besproken in separate rapporten. Een gezamenlijke korte samenvatting over alle deelstudies binnen dit bredere onderzoek naar excellentieonderwijs wordt eveneens gepresenteerd in een afzonderlijke bijdrage.

Wij willen onze dank betuigen aan een groot aantal mensen die bij de uitvoering van deze deelonderzoeken betrokken zijn geweest. Veel dank gaat uit naar de honderden studenten en de tientallen selecteurs die aan dit onderzoek hebben deelgenomen, en aan de docenten en coördinatoren van excellentieprogramma's die ons hebben geholpen bij het leggen en onderhouden van de contacten met de studenten. Verder bedanken wij onze collega's van CHEPS voor de prettige samenwerking, en voor de kritische en constructieve wijze waarop zij meegedacht hebben over onze deelstudies. Tot slot bedanken wij onze andere collega's bij ROA en KBA voor de ondersteuning bij de uitvoering van en rapportage over dit onderzoek.

Maastricht/Nijmegen, februari 2020

Kim van Broekhoven

Tim Huijts

Marieke Isendam

Madelon Jacobs
Renze Kolster

Bianca Leest

Christoph Meng

Maarten Wolbers 


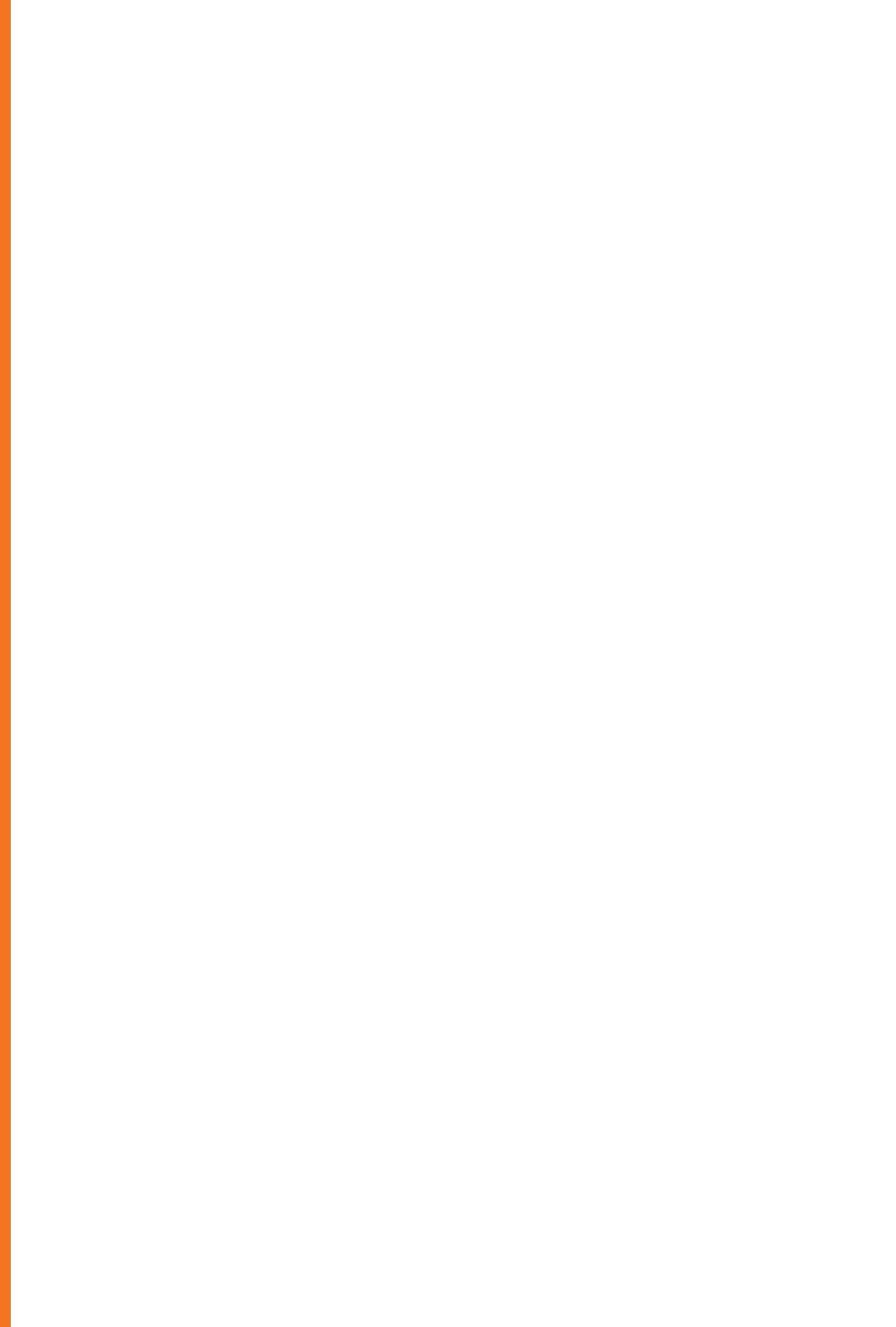




\section{SAMENVATTING}

In het afgelopen decennium is binnen het hoger onderwijs in Nederland geleidelijk meer aandacht gekomen voor verschillen tussen studenten en de vraag hoe het onderwijs daarop goed kan inspelen. Door differentiatie - het bieden van variëteit in de inhoud, de vorm en het niveau - kan het onderwijs beter op studenten worden afgestemd. Excellentieonderwijs is onderwijs gericht op studenten die zich in het reguliere onderwijs te weinig uitgedaagd voelen. Hiermee wordt het vizier scherper dan voorheen gericht op studenten die meer dan gemiddeld gemotiveerd en getalenteerd zijn.

De ontwikkeling van excellentieprogramma's aan de hogescholen en universiteiten werd gestimuleerd door het Sirius-subsidieprogramma. Dit programma liep van 2008 tot 2014 en had een budget van 60 miljoen euro. Het excellentieonderwijs heeft sindsdien opgang gemaakt in het gehele Nederlandse hoger onderwijs. Na het beëindigen van het Siriusprogramma spraken veel hoger onderwijsinstellingen de intentie uit om het excellentieonderwijs te blijven voortzetten, in het 'Manifest voor excellentieonderwijs van de toekomst'. Het Ministerie van OCW heeft deze intentie ondersteund met het onderzoeksprogramma Excellentie van het Nationaal Regieorgaan Onderwijsonderzoek (NRO). Immers, ondanks dat het excellentieonderwijs breed ingang heeft gevonden in het Nederlandse hoger onderwijs, is er nog maar weinig bekend over de opbrengsten en effecten ervan voor studenten en onderwijsinstellingen.

Niet alleen in visie, maar ook in naamgeving, organisatie, vormgeving, positie ten opzichte van de reguliere opleiding en disciplinaire oriëntatie bestaat er een grote varieteit aan excellentieonderwijs. Een gedeelde veronderstelling is echter dat er positieve effecten verwacht mogen worden van het excellentieonderwijs, zowel voor studenten als voor het onderwijs. Het voorliggende rapport is een verslag van twee van totaal drie deelstudies van onderzoek naar de effecten van excellentieonderwijs. In deze twee deelonderzoeken is ingegaan op de effectiviteit van selectie-instrumenten en de effecten van excellentieprogramma's op studenten. Op de effecten van het excellentieonderwijs op het reguliere onderwijs en de organisatie als geheel (de zogenaamde 'uitstralingseffecten'), en op het beeld dat werkgevers hebben van excellentieprogramma's, wordt ingegaan in twee separate rapporten. Een gezamenlijke korte samenvatting over alle deelstudies binnen dit bredere onderzoek naar excellentieonderwijs wordt eveneens gepresenteerd in een afzonderlijke bijdrage. 
We beantwoorden in dit rapport de volgende twee centrale onderzoeksvragen:

1. Hoe kan de selectie van kandidaten voor excellentieprogramma's verbeterd worden en welke instrumenten geven de beste match tussen persoon en programma?

2. Wat is de individuele toevoegende waarde van deelname aan excellentieprogramma's voor studenten voor zowel cognitieve als non-cognitieve vaardigheden?

We hebben vijf dataverzamelingsmethoden gebruikt om antwoord te geven op de onderzoeksvragen: (a) afname van online vragenlijsten en testen bij studenten; (b) verzamelen van administratieve gegevens bij studentenadministraties; (c) opvragen van selectie-oordelen bij selecteurs van excellentieprogramma's; (d) interviews met selecteurs van excellentieprogramma's; (e) afname van online vragenlijst met vignetten bij selecteurs. De hiermee verkregen data zijn vervolgens geanalyseerd middels diverse kwantitatieve en kwalitatieve analysetechnieken.

De online vragenlijsten zijn afgenomen bij twee cohorten studenten in excellentieprogramma's en studenten die niet aan een excellentieprogramma deelnamen. Hiermee hebben we gegevens verzameld over onder meer kritische denkvaardigheden, creativiteit, leiderschap, politieke betrokkenheid, motivatie, persoonlijkheidskenmerken en achtergrondkenmerken. Daarnaast is met coördinatoren van de excellentieprogramma's van deze instellingen gesproken over de wijze van selectie van studenten en zijn van twee cohorten studenten de selectieoordelen verzameld voor het onderzoek. Aan het einde van het programma is opgevraagd in hoeverre de studenten in de onderzochte twee cohorten het programma succesvol hebben afgerond. Als laatste is er onder selecteurs van excellentieprogramma's een vignettenonderzoek uitgezet waarmee zij zijn bevraagd over de kenmerken die volgens hen bepalend zijn voor de toelating tot een excellentieprogramma.

Met betrekking tot de eerste centrale onderzoeksvraag concluderen we dat de studenten die deelnamen aan excellentieprogramma's al bij de start van het programma hoger scoorden op de meeste cognitieve en non-cognitieve uitkomstmaten dan studenten in het regulier onderwijs. Wanneer er wordt gekeken naar de kans om deel te nemen aan excellentieprogramma's laten de resultaten zien dat kritisch denkvermogen en studieresultaten belangrijke factoren zijn om de deelname te voorspellen. Daarnaast is de kans op deelname aan excellentieprogramma's hoger voor studenten die meer intrinsiek en extrinsiek gemotiveerd en zorgvuldiger zijn. Ons onderzoek laat verder zien dat geen van de relevant geachte factoren een duidelijk effect hebben op de kans op succesvolle afronding van excellentieprogramma's. Uit de resultaten van deze analyses komt wel naar voren dat honoursstudenten die meer uren per week werken naast hun studie een kleinere kans hebben op succesvolle afronding van het excellentieprogramma.

In de vignettenanalyse die afgenomen is onder selecteurs van excellentieprogramma's komt sterk naar voren dat selecteurs gedurende het selectieproces de 'beste' studenten willen aannemen. Voor zowel hbo als wo geldt dat hogere cijfers en meer extracurri- 
culaire ervaringen zoals buitenlandervaring, studie-gerelateerde bijbaan en vrijwilligerswerk positief bijdragen aan de kans om aangenomen te worden voor excellentieprogramma's. Daarnaast spelen motivatie, denkvermogen, doorzettingsvermogen, maatschappelijke betrokkenheid en creativiteit een belangrijke rol in het aannemen van studenten.

De belangrijkste conclusie die getrokken kan worden met betrekking tot de tweede onderzoeksvraag is dat honoursstudenten die gedurende hun bachelor deel hebben deelgenomen aan excellentieprogramma's zich zowel op cognitieve en non-cognitieve uitkomstmaten positief hebben ontwikkeld. Echter, reguliere studenten maken een soortgelijke positieve groei door. Honoursstudenten verschillen daarin dus niet wezenlijk van studenten in het regulier onderwijs. Dit betekent overigens niet noodzakelijkerwijs dat honoursstudenten nadeel ondervinden van deelname aan excellentieprogramma's. Zo lijkt deelname aan excellentieprogramma's dus niet ten koste te gaan van bijvoorbeeld studieresultaten: honoursstudenten blijven gedurende hun gehele bachelorprogramma hogere studieresultaten behalen dan reguliere studenten. Over het algemeen halen honoursstudenten hogere scores op alle uitkomstmaten, waarbij de voornaamste verklaring is dat honoursstudenten al bij de start van de excellentieprogramma's beter op de meeste cognitieve en non-cognitieve uitkomstmaten scoorden dan studenten in het regulier onderwijs. Dit suggereert dat de belangrijkste verschillen tussen beide groepen voortkomen uit selectie van studenten voor excellentieprogramma's.

Op basis van ons onderzoek doen we diverse aanbevelingen voor beleidsmakers en beleidsuitvoerders op het gebied van excellentieonderwijs. Bij de selectie van studenten voor een excellentieprogramma, is de wens van zowel programma als student natuurlijk dat deze laatste het traject ook succesvol afrondt. Daarom wordt veel tijd en aandacht besteed aan de keuze van de juiste studenten. Helaas komen er in dit onderzoek geen specifieke instrumenten naar voren die het succesvol afronden van de programma's goed kunnen voorspellen. Wel is gebleken dat een hoge extrinsieke motivatie een onderscheidende factor is. Ook laten de resultaten zien dat honoursstudenten wél al bij de start van de excellentieprogramma's hoog en meestal beter scoren op de uitkomstmaten dan studenten in het regulier onderwijs. Dit lijkt erop te duiden dat selecteurs er wel in slagen de uitblinkers te selecteren voor excellentieprogramma's. De invloed van het inkomens- en opleidingsniveau van ouders geeft echter wel enige aanleiding tot reflectie op de selectie van honoursstudenten en de toegankelijkheid van excellentieprogramma's voor studenten met verschillende achtergronden.

Tevens blijkt uit dit onderzoek dat honoursstudenten zich positief ontwikkelen op zowel cognitief als non-cognitief gebied tijdens het volgen van een excellentieprogramma. Dit is een mooie uitkomst, maar omdat de resultaten ook laten zien dat reguliere studenten een soortgelijke groei doormaken, zou men kunnen concluderen dat het volgen van een excellentieprogramma overbodig is. Dit zou te kort door de bocht zijn; veel excellentietrajecten hebben namelijk niet het (enkele) doel om bepaalde cognitieve en noncognitieve vaardigheden van honoursstudenten te verbeteren, maar ook om bijvoor- 
beeld kennis te verbreden en verdiepen. Belangrijk is om gezamenlijk - docenten, coördinatoren, selecteurs, studenten - scherp te krijgen wat de leerdoelen zijn binnen het aangeboden programma. Waar willen we de groei zien, wat zijn de verwachtingen, wat willen studenten eruit halen? Excellentietrajecten zijn bij uitstek geschikt om een leertraject op maat te bieden: elke student ontwikkelt zich op andere domeinen, dus leeruitkomsten en -opbrengsten zullen ook per persoon verschillend zijn. Dit past ook bij de doelstelling van talentontwikkeling die een van de kernelementen van excellentieonderwijs vormt: de onderwijsinstelling biedt onderwijs waarin alle studenten optimaal kunnen presteren, onafhankelijk van de vraag hoe talentvol zij zijn. Op deze manier is het mogelijk dat de groei die studenten in excellentieprogramma's hebben doorgemaakt alsnog deels te danken is aan het volgen van deze programma's, en aan de'match' tussen specifieke studenten en programma's. 


\section{INLEIDING}

\subsection{Achtergrond}

In het afgelopen decennium is binnen het hoger onderwijs in Nederland geleidelijk meer aandacht gekomen voor verschillen tussen studenten en de vraag hoe het onderwijs daarop goed kan inspelen. Door differentiatie - het bieden van variëteit in de inhoud, de vorm en het niveau - kan het onderwijs beter op studenten worden afgestemd. Excellentieonderwijs is onderwijs gericht op studenten die zich in het reguliere onderwijs te weinig uitgedaagd voelen. Hiermee wordt het vizier scherper dan voorheen gericht op studenten die meer dan gemiddeld gemotiveerd en getalenteerd zijn.

Excellentieonderwijs komt oorspronkelijk uit de Verenigde Staten (Van Eijl et al., 2007; Humphrey, 2008). In Nederland is excellentieonderwijs in de vorm van excellentieprogramma's van start gegaan in 1993; enkele jaren later volgde het eerste 'university college' (Wolfensberger et al., 2004). De ontwikkeling van excellentieprogramma's aan de hogescholen en universiteiten werd gestimuleerd door het Sirius-subsidieprogramma. Dit programma liep van 2008 tot 2014 en had een budget van 60 miljoen euro. Het excellentieonderwijs heeft sindsdien opgang gemaakt in het gehele Nederlandse hoger onderwijs (Wolfensberger, 2015). Na het beëindigen van het Siriusprogramma spraken veel hoger onderwijsinstellingen de intentie uit om het excellentieonderwijs te blijven voortzetten, in het 'Manifest voor excellentieonderwijs van de toekomst'. Het Ministerie van OCW heeft deze intentie ondersteund met het onderzoeksprogramma Excellentie van het Nationaal Regieorgaan Onderwijsonderzoek (NRO). Immers, ondanks dat het excellentieonderwijs breed ingang heeft gevonden in het Nederlandse hoger onderwijs, is er nog maar weinig bekend over de opbrengsten en effecten ervan voor studenten en onderwijsinstellingen.

Onderzoekers van ITS, ROA en CHEPS (zie Allen et al., 2015) hebben in hun evaluatie van het Sirius-programma drie excellentievisies onderscheiden:

- Talentontwikkeling: de onderwijsinstelling biedt onderwijs waarin alle studenten optimaal kunnen presteren, onafhankelijk van de vraag hoe talentvol zij zijn.

- Excellent onderwijs voor excellente studenten: hierbij ligt de focus op studenten met bewezen meer dan gemiddeld talent en motivatie, die door speciaal vormge- 
geven onderwijs een buitengewoon hoge prestatie leveren die verder gaat dan het behalen van hoge cijfers in een regulier programma.

- Excellentie als innovatie: gemotiveerde studenten (min of meer onafhankelijk van de vraag hoe talentvol zij zijn) de uitdaging geven om buiten gebaande paden te treden. Excellentieprogramma's zijn daarbij, behalve plekken voor verdiepend/ verbredend onderwijs, vooral ook plaatsen waar geëxperimenteerd wordt met nieuwe onderwijsvormen en met nieuwe visies op leren.

Niet alleen in visie, maar ook in naamgeving, organisatie, vormgeving, positie ten opzichte van de reguliere opleiding en disciplinaire oriëntatie bestaat er een grote variëteit aan excellentieonderwijs. Excellentieonderwijs komt voor onder benamingen zoals honoursprogramma's, talentenprogramma's, 'talent academies' et cetera. Voor de leesbaarheid (en in lijn met het onderzoeksprogramma Excellentie van het NRO) hanteren we in dit rapport de termen 'excellentieonderwijs' en 'honoursstudenten'.

Een gedeelde veronderstelling is echter dat er positieve effecten verwacht mogen worden van het excellentieonderwijs, zowel voor studenten als voor het onderwijs. Het voorliggende rapport is een verslag van twee van totaal drie deelstudies van onderzoek naar de effecten van excellentieonderwijs. In deze twee deelonderzoeken is ingegaan op de effectiviteit van selectie-instrumenten en de effecten van excellentieprogramma's op studenten. Op de effecten van het excellentieonderwijs op het reguliere onderwijs en de organisatie als geheel (de zogenaamde 'uitstralingseffecten'), en op het beeld dat werkgevers hebben van excellentieprogramma's, wordt ingegaan in twee separate rapporten.

\subsection{Selectie van studenten}

Het bekende drieringenmodel van Renzulli (1978) stelt dat er drie conceptueel te onderscheiden ingrediënten zijn voor excellentie: bekwaamheid, taaktoewijding en creativiteit (vertaling overgenomen van Coppoolse et al., 2013). Een recent onderzoek (Kolster, van Dijk \& Jongbloed, 2016) bevestigt het bestaan van deze drie typen en laat zien dat er overlap is, dat wil zeggen dat studenten zowel bovengemiddeld bekwaam, als creatief als taaktoegewijd kunnen zijn. Deze 'ingrediënten' van excellente studenten zien we ook terug in de selectiecriteria en -procedures voor excellentieprogramma's. Sommige programma's gebruiken een aantal formele criteria, zoals het gemiddeld studiecijfer. Andere kijken vooral naar de motivatie, die moet blijken uit een brief of uit een gesprek met de student. Criteria en procedures verschillen echter zowel tussen instellingen als tussen programma's binnen instellingen en er is bovendien weinig bekend over de effectiviteit van de gebruikte selectiecriteria en -instrumenten. Het selectieve karakter vormt daarmee de aanleiding voor een vraag die voortkomt uit de praktijk van de excellentieprogramma's: Vindt op basis van deze selectie een goede match plaats tussen student en programma en hoe kan de effectiviteit van die selectie (verder) verbeterd worden? 


\subsection{Effecten van excellentieprogramma's}

Het gros van de literatuur over excellentieprogramma's analyseert het effect van excellentieprogramma's puur in de vorm van behaalde studieresultaten. Bui et al. (2011) concluderen echter dat excellentieprogramma's ook andere resultaten hebben dan alleen behaalde studieresultaten. Deze conclusie wordt ondersteund door Kool et al. (2017) en Ghanizadeh (2017) die constateren dat studenten zich ook ontwikkelen op andere gebieden, zoals het kritisch denkvermogen. Zowel cognitieve uitkomsten zoals kritisch denken en behaalde cijfers als non-cognitieve vaardigheden zoals creativiteit zijn belangrijke uitkomstmaten van het onderwijs (Renzulli, 2002). Er is echter nog weinig bekend over de effecten van excellentieprogramma's op voorgenoemde vaardigheden van studenten. Daarbij zijn de geselecteerde studenten in excellentieprogramma's een bijzondere groep. Zij worden juist geselecteerd omdat ze bijvoorbeeld meer gemotiveerd zijn en goede studiestudieresultaten hebben behaald. De vraag is dan wat het separate effect van excellentieprogramma's is wanneer rekening wordt gehouden met deze selectie-effecten.

De uitkomstmaten van excellentieprogramma's waar in dit onderzoek naar worden gekeken zijn kritisch denken, creativiteit, leiderschap, politieke betrokkenheid en studieresultaten. Kool et al. (2017) beargumenteren dat er verder moet worden gekeken dan naar alleen academische uitkomsten omdat excellentieprogramma's zich niet alleen focussen op academische resultaten. Het behalen van hoge cijfers is niet het doel van excellentieprogramma's maar meer het ontwikkelen van de vaardigheden (Hernández-Torrano \& Saranli, 2015). Gebaseerd op onderzoek naar excellentieprogramma's van Renzulli (2002) worden meer uitkomstmaten meegenomen die vaak als belangrijk worden bestempeld zoals kritisch denken en creativiteit. Excellentieprogramma's hebben als doel om de studenten essentiële vaardigheden voor de 21e eeuw aan te leren (Heijltjes, 2014) en om de studenten op te leiden tot succesvolle professionals (Scager et al., 2012). Hier dragen een aantal belangrijke vaardigheden aan bij, zoals kritisch denken, creativiteit, leiderschap en politieke betrokkenheid. Het is daarom van belang om al deze verschillende vaardigheden, samen met studieresultaten, te testen onder de studenten en naar de groei in deze vaardigheden te kijken voor studenten in excellentieprogramma's.

\subsection{Onderzoeksvragen}

In dit rapport worden twee aspecten van excellentieprogramma's onderzocht, namelijk de selectie in excellentieprogramma's en de effectiviteit van deze programma's. Om de effectiviteit van de selectie voor excellentieprogramma's te onderzoeken zijn de volgende onderzoeksvragen geformuleerd:

\section{Hoofdvraag 1:}

Hoe kan de selectie van kandidaten voor excellentieprogramma's verbeterd worden en welke instrumenten geven de beste match tussen persoon en programma? 
Subvragen:

- Hoe is de selectie bij de onderzochte excellentieprogramma's vormgegeven; welke criteria en procedures hanteren zij?

- Op welke eigenschappen en vaardigheden onderscheiden studenten die deelnemen aan excellentieprogramma's zich van studenten die niet deelnemen?

- Welke eigenschappen en vaardigheden van studenten zijn voorspellend voor hun succes in een excellentieprogramma?

- Welke preferenties hanteren selecteurs van excellentieprogramma's aan hogescholen en universiteiten?

Hoofdvraag 2:

Wat is de individuele toevoegende waarde van deelname aan excellentieprogramma's voor studenten voor zowel cognitieve als non-cognitieve vaardigheden?

\subsection{Opbouw van het rapport}

In dit rapport beschrijven we stap voor stap hoe we onze twee hoofdvragen beantwoord hebben. In hoofdstuk 2 lichten we toe welke data we verzameld hebben voor dit onderzoek, en hoe we bij de dataverzameling precies te werk gegaan zijn. We lichten daarbij ook toe hoe de data aansluiten bij onze vraagstelling, en hoe we de verzamelde data bewerkt hebben om ze klaar te maken voor verdere analyse. Hoofdstuk 3 richt zich vervolgens op de beantwoording van onze eerste hoofdvraag. We brengen selectieprocessen voor excellentieprogramma's in kaart, en leiden hieruit af op welke manieren de selectieprocessen van verschillende instellingen op elkaar lijken of zich juist van elkaar onderscheiden. In dit hoofdstuk analyseren we verder op welke eigenschappen en vaardigheden studenten die deelnemen aan excellentieprogramma's zich onderscheiden van studenten die niet deelnemen, en welke eigenschappen en vaardigheden van studenten voorspellend zijn voor het al dan niet succesvol afronden van excellentieprogramma's. We eindigen hoofdstuk 3 met een analyse van de preferenties van selecteurs van excellentieprogramma's, om te achterhalen welke eigenschappen, vaardigheden en ervaringen selecteurs vooral van belang vinden voor studenten die deelnemen aan excellentieprogramma's. In hoofdstuk 4 verschuiven we onze focus naar de beantwoording van de tweede hoofdvraag. We presenteren een analyse van de effecten van deelname aan excellentieprogramma's op een reeks cognitieve en non-cognitieve vaardigheden, om op deze manier in beeld te brengen wat de individuele toegevoegde waarde van excellentieprogramma's is. In hoofdstuk 5 zetten we de belangrijkste conclusies van het onderzoek op een rij, we bespreken discussiepunten voor wetenschap en beleid, en we doen aanbevelingen voor beleidsmakers van de hogeronderwijsinstellingen en hun medewerkers die in excellentieprogramma's betrokken zijn en voor vervolgonderzoek. 


\section{DATAVERZAMELING VAN ONDERZOEK}

In dit hoofdstuk wordt beschreven welke vijf dataverzamelingsmethoden zijn gebruikt om antwoord te geven op de onderzoeksvragen':

a. Afname van online vragenlijsten en testen bij studenten;

b. Verzamelen van administratieve gegevens bij studentenadministraties;

c. Opvragen van selectie-oordelen bij selecteurs van excellentieprogramma's;

d. Interviews met selecteurs van excellentieprogramma's;

e. Afname van online vragenlijst met vignetten bij selecteurs.

Bij twee cohorten studenten in excellentieprogramma's en studenten die niet aan een excellentieprogramma deelnamen zijn online vragenlijsten afgenomen. Hiermee hebben we gegevens verzameld over onder meer kritische denkvaardigheden, creativiteit, leiderschap, politieke betrokkenheid, motivatie, persoonlijkheidskenmerken en achtergrondkenmerken. Daarnaast is met coördinatoren van de excellentieprogramma's van deze instellingen gesproken over de wijze van selectie van studenten en zijn van twee cohorten studenten de selectieoordelen verzameld voor het onderzoek. Aan het einde van het programma is opgevraagd in hoeverre de studenten in de onderzochte twee cohorten het programma succesvol hebben afgerond. Als laatste is er onder selecteurs van excellentieprogramma's een vignettenonderzoek uitgezet waarmee zij zijn bevraagd over de kenmerken die volgens hen bepalend zijn voor de toelating tot een excellentieprogramma. In dit hoofdstuk wordt voor elk van deze databronnen kort de dataverzameling en welke gegevens hiermee verkregen zijn beschreven.

In Tabel 1 staat een schematisch overzicht van de kenmerken van de excellentieprogramma's die in dit onderzoek worden onderzocht met meer informatie overde omvang en looptijd van het excellentieprogramma, de aard van het programma en het curriculum. Dit schema is tot stand gekomen naar aanleiding van interviews met de selecteurs van de excellentieprogramma's. De keuze van de programma's is gebaseerd op de contacten met de Universiteit Maastricht, de Universiteit Twente en de HAN die waren opgebouwd vanuit de evaluatie van het Siriusprogramma en de wens die er bij deze onderwijsinstellingen lag om meer kennis op te doen over selectie en effecten. Vervolgens hebben we de samenwerking verder regionaal uitgebreid met de Radboud Universiteit en Hanze Hogeschool. Op deze wijze zijn we gekomen tot acht te onderzoeken excellentieprogramma's.

$1 \quad$ Alle instrumenten die voor de vijf dataverzamelingsmethoden gebruikt zijn zullen via DANS beschikbaar gemaakt worden voor inzage. 


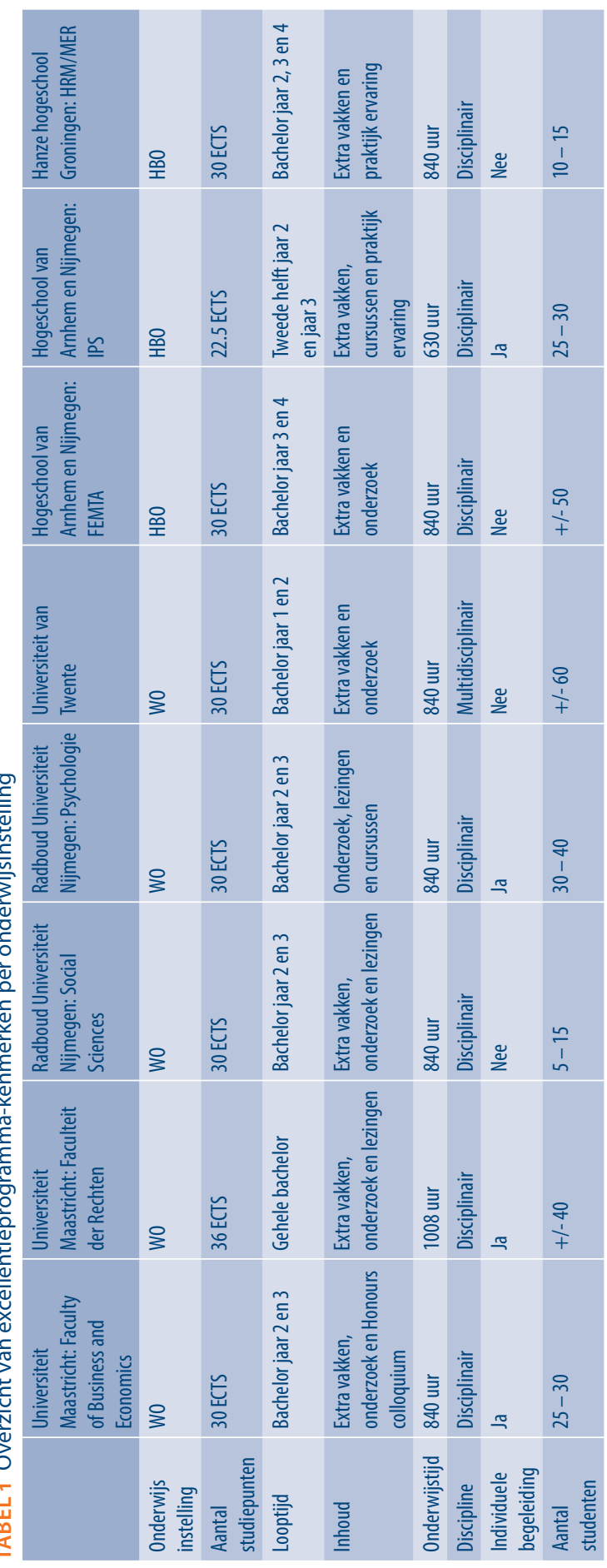




\subsection{Vragenlijst voor studenten van excellentieprogramma's en reguliere programma's}

\subsubsection{Opzet dataverzameling}

Bij de drie universiteiten en twee hogescholen die deelnamen aan het onderzoek zijn zowel studenten in excellentieprogramma's als studenten die niet deelnamen aan een excellentieprogramma uitgenodigd om vragenlijsten in te vullen. De tweede groep dient als controlegroep, om de vergelijking te kunnen maken met studenten in excellentieprogramma's, voor de beantwoording van de twee hoofdvragen van het onderzoek. Er zijn twee studentencohorten betrokken in het onderzoek: studenten die in studiejaar 2016/17 en in studiejaar 2017/18 startten met een excellentieprogramma. Deze studenten zijn bevraagd bij aanvang van hun excellentieprogramma. Studenten die niet deelnamen aan excellentieprogramma's werden op hetzelfde moment in hun studieloopbaan bevraagd. ${ }^{2}$ Aan het einde van het excellentieprogramma, na ruim anderhalf jaar, zijn beide groepen studenten voor de tweede maal bevraagd.

Om een goede respons te stimuleren hebben we onder meer de volgende maatregelen genomen:

- Studenten in excellentieprogramma's zijn veelal voor het onderzoek uitgenodigd door de coördinatoren van het programma en door hen gewezen op het belang van deelname.

- De afname van de nulmeting vond plaats op locatie. Studenten konden een voor hen geschikt moment aangeven waarop op locatie op hun hogeschool of universiteit deelgenomen kon worden aan het onderzoek. De eindmeting is vrijwel volledig online afgenomen (enkele studenten hebben ook op locatie aan de eindmeting deelgenomen).

- Bij de nulmeting kregen deelnemers voorafgaand aan het invullen van de vragenlijsten van een van de betrokken onderzoekers een mondelinge toelichting bij het onderzoek en instructie voor het invullen van de vragenlijsten. Bij de eindmeting vond de toelichting online schriftelijk plaats.

- Deelnemende studenten hebben na deelname aan elke meting een feedbackrapport ontvangen met hun eigen resultaten, vergeleken met de gemiddelde resultaten.

- Studenten in de controlegroep (en studenten van enkele excellentieprogramma's) kregen een vergoeding in de vorm van een cadeaubon (in de meeste gevallen ter waarde van in totaal 25 euro).

Zowel in het eerste als in het tweede cohort is er uitval van studenten die niet hebben deelgenomen aan de eindmeting. $49 \%$ van de respondenten die deelnamen aan de

2 De precieze timing van de vragenlijst en benadering van studenten staat in Bijlage 1. 
nulmeting van dit onderzoek heeft niet deelgenomen aan de eindmeting ${ }^{3}$. Onderstaande tabellen laten de respons voor de twee cohorten zien.

TABEL 2 Aantallen per instelling voor studentencohort 1

\begin{tabular}{|l|r|r|r|r|r|r|} 
& \multicolumn{3}{|c|}{ Nulmeting } & \multicolumn{3}{|c|}{ Eindmeting } \\
& Regulier & Honours & Totaal & Regulier & Honours & Totaal \\
\hline Universiteit Mastricht & 165 & 56 & 221 & 85 & 21 & 106 \\
\hline University College Maastricht* & & 158 & 158 & & 38 & 38 \\
\hline Radboud Universiteit & 34 & 27 & 61 & 23 & 23 & 46 \\
\hline Hanze Hogeschool & 15 & 19 & 34 & 9 & 9 & 18 \\
\hline Universiteit Twente & 66 & 58 & 124 & 48 & 27 & 75 \\
\hline Hogeschool Arnhem Nijmegen & 72 & 59 & 131 & 34 & 23 & 56 \\
\hline Totaal & 352 & 377 & 729 & 199 & 141 & 340 \\
\hline
\end{tabular}

*De vragenlijst voor studenten van University College Maastricht wijkt iets af van de overige instellingen, hierbij zat een grotere tijdsperiode tussen de nulmeting en eindmeting. Voor de precieze timing zie tabel A1 in de bijlage.

TABEL 3 Aantallen per instelling voor studentencohort 2

\begin{tabular}{|l|r|r|r|r|r|r|} 
& \multicolumn{3}{|c|}{ Nulmeting } & \multicolumn{3}{|c|}{ Eindmeting } \\
& Regulier & Honours & Totaal & Regulier & Honours & Totaal \\
\hline Universiteit Maastricht & 128 & 78 & 206 & 91 & 47 & 138 \\
\hline Radboud Universiteit & 31 & 29 & 60 & 24 & 15 & 39 \\
\hline Hanze Hogeschool & 5 & 11 & 16 & 3 & 3 & 6 \\
\hline Universiteit Twente & 40 & 82 & 122 & 32 & 23 & 55 \\
\hline Hogeschool Arnhem Nijmegen & 34 & 43 & 77 & 24 & 15 & 39 \\
\hline Totaal & 238 & 243 & 481 & 174 & 103 & 277 \\
\hline
\end{tabular}

\subsubsection{Vragenlijst en variabelen}

In dit onderzoek naar de effectiviteit van de selectie van studenten voor excellentieprogramma's en de toegevoegde waarde van de programma's wordt naar meerdere uitkomstmaten gekeken. Er zijn zowel cognitieve vaardigheden zoals kritisch denken en creativiteit gemeten, alsook non-cognitieve vaardigheden zoals leiderschap en politieke betrokkenheid. Daarnaast zijn er andere aspecten van het profiel van studenten gemeten, zoals motivatiekenmerken, persoonlijkheidsaspecten, tijdsbesteding en sociale achtergrond die van invloed kunnen zijn op selectie en effectiviteit.

In deze paragraaf bespreken we de keuze van vaardigheden en kenmerken die zijn gemeten en de instrumenten, schalen en items die hiervoor zijn gebruikt. De beschrijvende statistieken staan in bijlage 2 .

De studenten die deelnamen aan het onderzoek hebben de Watson-Glaser Test gemaakt om hun kritische denkvaardigheden te meten, de Alternate Uses Test om creativiteit te

3 Een uitval van $49 \%$ in paneldata is een relatief normale uitval. Sudman \& Ferber (1979) tonen aan dat een gemiddelde van $50 \%$ van de respondenten in panel studies uitvalt. 
meten en ze hebben een aanvullende vragenlijst beantwoord waarmee andere vaardigheden en kenmerken zijn gemeten.

\section{Kritisch denken}

Kritisch denken is gemeten aan de hand van zowel een objectieve maat, de WatsonGlaser test als een subjectieve maat, een zelf-gerapporteerde schaal van vijf items. Op basis van ervaringen in de evaluatie van het Sirius-subsidieprogramma (Allen et al.,2015) en vooronderzoek is ervoor gekozen om de vaardigheid kritisch denken te meten met behulp van de 'Watson-Glaser Test for Critical Thinking' (WG). Kritisch denken wordt gezien als een essentiële vaardigheid voor de 21e eeuw (Heijltjes, 2014), voor het onderzoeken en beoordelen van informatie, het bepalen van standpunten en het nemen van weloverwogen beslissingen (SLO, 2019). Er is wereldwijd een aantal veelgebruikte gestandaardiseerde testen beschikbaar voor objectieve metingen van kritische denkvaardigheden. In dit onderzoek is uiteindelijk voor de Watson-Glaser test van Pearson/ Talent Lens gekozen omdat deze test geschikt is voor het meten van kritische denkvaardigheden van hoger opgeleiden, zowel in het Nederlands als het Engels beschikbaar is, vaker gebruikt wordt in wetenschappelijk onderzoek, veel wordt gebruikt in het bedrijfsleven en met een afnametijd van dertig minuten ook praktisch inpasbaar was in het onderzoek.

De Watson-Glaser test bevat 40 items die betrekking hebben op conclusies en gevolgtrekkingen, herkennen van foutieve aannames en evaluatie van argumenten. Voor dit onderzoek kon voor de eindmeting niet meer dezelfde versie van de Watson-Glaser test worden gebruikt als voor de nulmeting (WG II versus WG III) omdat Watson-Glaser de oude versie niet meer aanbood. Dit heeft als gevolg dat de uitkomsten niet een-op-een vergeleken kunnen worden, maar wel door middel van de percentile en stanine scores. De percentile score is een percentielscore van o tot 99 die de studenten verdeelt in 100 gelijke categorieën in oplopende volgorde: hoe hoger de percentile score, hoe beter de student heeft gescoord vergeleken met alle andere studenten. Deze percentielscore is gebaseerd op de normgroep ${ }^{4}$ waarin de test is afgenomen, gebaseerd op alle mensen die ooit de Watson-Glaser test hebben afgenomen. Een score van 43 betekent dat $43 \%$ van iedereen binnen de normgroep een slechtere score had, en $57 \%$ een betere score had. De stanine score is eveneens een veelgebruikte standaardscore. Deze score kan lopen van' 1 = laagste score' tot en met ' $9=$ hoogste score'.

Naast de Watson-Glaser test heeft er een subjectieve meting van kritisch denken plaatsgevonden, welke gebaseerd is op 'learning strategies' van Pintrich, Garcia, McKeachie, \& Smith (1991) met zelf-gerapporteerde items zoals 'lk stel zaken die ik hoor of lees in een studieonderdeel vaak ter discussie om te bepalen of ik ze overtuigend vind' en 'lk beschouw het studiemateriaal als uitgangspunt en probeer mijn eigen ideeën erover te ontwikkelen' waarbij de student kon antwoorden met ' $1=$ helemaal niet' tot ' $5=$ zeer

4 De normgroep voor nederlandse studenten is "werkende volwassenen" en voor internationale studenten is de normgroep "Bachelor degree". Binnen deze normgroep worden de scores bepaald voor de studenten gebaseerd op iedereen die ooit binnen deze normgroep getoetst is. 
sterk'. De schaal is voldoende betrouwbaar om kritisch denken te meten $(a=0.71)$. Deze objectieve en subjectieve meting van kritisch denken zijn complementair aan elkaar, ze meten niet dezelfde onderliggende concepten van kritisch denken. $\mathrm{Er}$ is dan ook geen significante correlatie tussen de zelf-gerapporteerde meting en de objectieve meting ( $r$ $=0.014 ; \mathrm{p}=0.672$ voor stanine en $\mathrm{r}=0.021 ; \mathrm{p}=0.516$ voor percentile scores). De subjectieve meting van kritisch denken is gebaseerd op andere dimensies dan de WatsonGlaser test, waardoor deze metingen verschillen van aard. De Watson-Glaser test is ontwikkeld om kritisch denken te meten voor professioneel en academisch gebruik (Watson \& Glaser, 2010) en meet voornamelijk vaardigheden ten aanzien van het trekken van conclusies en gevolgtrekkingen. De zelf-gerapporteerde schaal heeft voornamelijk betrekking op kritisch denken in het onderwijs van de studenten. In de analyses wordt zowel de objectieve als de subjectieve meting van kritisch denken meegenomen.

\section{Creativiteit}

Creativiteit wordt gezien als een belangrijke vaardigheid die vaak wordt verbonden aan excellentieprogramma's. Renzulli (2002) benoemt een creatieve student als een student die flexibel is, openstaat voor nieuwe ervaringen en ideeën en nieuwsgierig is, maar ook het 'out-of-the-box' kan denken. Excellentieprogramma's hebben als doel om de studenten op te leiden tot succesvolle professionals (Scager et al., 2012) waarbij creativiteit wordt gezien als een van de benodigdheden om een succesvolle professional te worden (Kool et al., 2017). In deze studie wordt creativiteit meegenomen om zowel de selectie als de effecten van excellentieprogramma's nader te bestuderen, waarbij creativiteit op twee manieren is gemeten, namelijk aan de hand van een 'Alternate Uses Test' (AUT; Guilford, 1967) en een zelf-gerapporteerde subjectieve meting van een tiental stellingen die zijn afgeleid van de 'Creative Achievement Questionnaire (CAQ)' van Carson et al. (2005).

In de Alternate Uses Test (Guilford, 1967) wordt de studenten gevraagd om zoveel mogelijk verschillende gebruiksmogelijkheden te verzinnen bij bepaalde objecten, zoals bijvoorbeeld een potlood of een autoband. Hieruit kunnen vervolgens drie verschillende metingen van creativiteit worden afgeleid, namelijk fluency (het aantal geaccepteerde antwoorden), flexibiliteit (het aantal categorieën waarbinnen de antwoorden vallen) en doorzettingsvermogen (het aantal geaccepteerde antwoorden over het aantal categorieën). Voor de eerste twee metingen geldt hoe hoger de score, hoe hoger de creativiteit. Voor de laatste categorie, doorzettingsvermogen, geldt hoe lager de score, hoe hoger de creativiteit aangezien het een ratio is van de eerste twee categorieën. Reiter-Palmon, Forthman \& Barbot (2019) beargumenteren dat de meeste studies de fluency score rapporteren, echter moet flexibiliteit ook meegenomen worden. Deze score geeft aan dat een student ook in verschillende categorieën kan denken en kan een aanvullende indicator voor creativiteit zijn. De scores voor fluency lopen van o tot 28 geaccepteerde antwoorden. De scores op flexibiliteit lopen van o tot 34 geaccepteerde categorieën. De scores op doorzettingsvermogen lopen van o tot 14.7 . 
De subjectieve meting is afgeleid van de 'Creative Achievement Questionnaire (CAQ)' van Carson et al. (2005), waarin creativiteit en creatieve vaardigheden worden gezien als de optelsom van creativiteit op diverse gebieden. In de vragenlijst wordt aan de student gevraagd hoe creatief hij/zij zichzelf vindt op diverse gebieden zoals wiskunde, schrijven, ambacht of problemen oplossen, waarbij de student kan antwoorden op een schaal van ' 1 = helemaal niet' tot ' $5=$ zeer creatief'. De CAQ schaal van Carson et al. (2005) extern gevalideerd op basis van grotere onderzoeken. In dit onderzoek is de schaal voldoende betrouwbaar om creativiteit te meten $(a=0.70)$. De correlatie tussen de zelfgerapporteerde creativiteit en fluency is significant $(r=0.074 ; p=0.018)$, de correlatie met flexibiliteit is niet significant $(r=0.048 ; p=0.119)$ en de correlatie met doorzettingsvermogen is ook niet significant $(r=0.009 ; p=0.784)$. Deze uitkomst is niet verassend aangezien de subjectieve meting van creativiteit over een veelheid aan dimensies van creativiteit gaat, van wiskunde en schrijven, tot problemen oplossen en kunst. Dit meet een hele andere creativiteit dan de AUT, die vooral creatief denken meet. In de analyses worden beide metingen van creativiteit meegenomen, omdat excellentieprogramma's de nadruk op verschillende vormen van creativiteit kunnen leggen.

\section{Leiderschap}

Leiderschap is gemeten aan de hand van IPIP schalen (Goldberg et al., 2006) waarbij gebruik wordt gemaakt van de zeven items gedefinieerd door Peterson \& Seligman (2004). Hiervoor is gekozen omdat het veelgebruikte schalen zijn die eerder gevalideerd zijn $(a=0.78)$. De items in deze schaal zijn bijvoorbeeld 'Ik probeer iedereen in een groep het gevoel te geven dat ze erbij horen' en'lk vind het moeilijk anderen te bewegen om met elkaar samen te werken' waarop de student kon antwoorden met ' 1 = helemaal

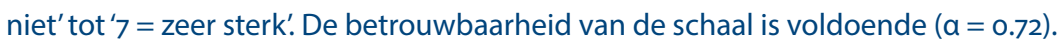

\section{Politieke betrokkenheid}

Politieke betrokkenheid is gemeten aan de hand van een schaal die specifiek voor dit onderzoek is geconstrueerd, met items over politieke en maatschappelijke betrokkenheid zoals 'Gestemd in de laatste landelijke verkiezingen' of 'Contact opgenomen met een politicus of een plaatselijke overheidsvertegenwoordiger' waarbij de student kon antwoorden met ' $1=j a$ ' of ' $2=$ nee.' De betrouwbaarheid van de schaal is voldoende ( $a$ $=0.76$ ). Omdat deze schaal erg gebonden is aan een nationale context (bijvoorbeeld vanwege het item over landelijke verkiezingen), en ook internationale studenten deelnemen aan excellentieprogramma's en aan het onderzoek, is er een tweede aanvullende schaal geconstrueerd voor politiek betrokkenheid die niet aan een nationale context gebonden is $(a=0.73)$.

\section{Overige gemeten kenmerken van studenten}

Om andere aspecten van het profiel van de studenten goed te kunnen meten, worden verschillende concepten gebruikt met betrekking tot motivatie, doorzettingsvermogen en persoonlijkheid. De keuze van deze concepten is gebaseerd op informatie verkregen uit de interviews met de selecteurs van excellentieprogramma's waaruit deze naar voor kwamen als belangrijke vaardigheden of eigenschappen die een rol kunnen spelen 
in de selectie van studenten voor excellentieprogramma's en/of als factoren die van invloed zijn op het studiesucces (zie ook paragraaf 2.4). De volgende concepten zijn steeds gebaseerd op meerdere items, die zowel bij de nulmeting als bij de eindmeting in de vragenlijst opgenomen zijn. Om de betrouwbaarheid van de schalen die deze concepten meten te bepalen, is steeds Cronbach's alpha gebruikt.

Motivatie wordt uitgesplitst naar intrinsieke en extrinsieke motivatie. Intrinsieke motivatie is gemeten aan de hand van vier items, zoals 'lk geef de voorkeur aan uitdagend studiemateriaal zodat ik nieuwe dingen kan leren' en 'Als het mogelijk is, kies ik het liefste cursusopdrachten waarvan ik kan leren, zelfs als ze geen hoog cijfer garanderen'. Studenten konden antwoorden met ' $1=$ helemaal niet' tot ' $7=$ zeer sterk'. De schaal is voldoende betrouwbaar schaal om intrinsieke motivatie te meten $(\alpha=0.59)$. Extrinsieke motivatie is gemeten aan de hand van vier andere items, zoals 'Het allerbelangrijkste is voor mij op dit moment om een hoog gemiddeld cijfer te behalen' en 'Ik wil goed presteren in mijn opleiding omdat het belangrijk voor me is om te laten zien wat ik kan aan mijn familie, vrienden, werkgever of anderen'. Studenten konden hierop antwoorden met ' 1 = helemaal niet' tot ' $7=$ zeer sterk'. De schaal is voldoende betrouwbaar schaal om extrinsieke motivatie te meten $(\alpha=0.72)$. Beide schalen zijn afkomstig van Pintrich et $a$. (1991).

Grit is een belangrijk concept dat doorzettingsvermogen meet in combinatie met passie en motivatie voor langdurig resultaat. Het concept is uitgesplitst naar 'consistentie van interesse' en 'volharding van inzet'. De schalen voor de Grit dimensies zijn afkomstig van Duckworth et al. (2007). Uit het onderzoek van Duckworth et al. (2007) blijkt dat Grit ongeveer $4 \%$ van 'succes' kan verklaren doordat het verder kijkt dan alleen IQ en persoonlijkheidskenmerken. Hieruit blijkt dat Grit belangrijk is om mee te nemen om te zien of langdurige focus en doorzettingsvermogen bij studenten verschilt. Consistentie van interesse is gemeten aan de hand van zes items zoals 'Ik vind het moeilijk om mij te blijven concentreren op projecten die langer dan een paar maanden duren' en 'Nieuwe ideeën en nieuwe projecten leiden mij soms af van wat ik me eerder had voorgenomen' waarbij de student kon antwoorden van' $1=$ helemaal niet zoals ik' tot ' $5=$ helemaal zoals $i k$ '. De betrouwbaarheid van de schaal is voldoende $(a=0.77)$. Volharding van inzet is gemeten aan de hand van zes items, zoals 'lk heb tegenslagen overwonnen om een belangrijke uitdaging tot een goed einde te brengen' en 'Ik ben een harde werker' waarbij de student kon antwoorden van' $1=$ helemaal niet zoals $i k^{\prime}$ tot ' $5=$ helemaal zoals $i k$ '. Ook de betrouwbaarheid van deze schaal is voldoende $(a=0.62)$.

Zelfeffectiviteit is het vertrouwen dat iemand heeft in zijn eigen doen en kunnen en wordt gezien als een belangrijk element van motivatie. Zelfeffectiviteit is gemeten aan de hand van tien items zoals 'lk voltooi taken met succes' en 'lk weet hoe ik dingen voor elkaar moet krijgen' waarbij de student kon antwoorden van ' $1=$ helemaal niet' tot ' $7=$ zeer sterk'. De betrouwbaarheid van de schaal is voldoende $(a=0.77)$. De schaal voor zelfeffectiviteit is afkomstig van Midgley et al. (2000). 
Risicopreferentie heeft betrekking op het opzoeken of vermijden van risico's in het dagelijks leven. Dit concept wordt gemeten aan de hand van de volgende vraag: 'Hoe zie je jezelf: Ben je over het algemeen genomen een persoon die volledig bereid is om risico's te nemen of probeer je risico's te vermijden?' waarbij de student kon antwoorden op een schaal van ' $\mathrm{o}=$ niet bereid om risico's te nemen' tot ' $10=$ volledig bereid om risico's te nemen'. Deze vraag is afkomstig van Dohmen et al. (2011).

Daarnaast worden zowel in de nulmeting als in de eindmeting een aantal persoonlijkheidskenmerken van de studenten bevraagd aan de hand van de vijf Big Five persoonlijkheidsdimensies (Goldberg, 1993). Voor dit onderzoek wordt een versie van Big Five persoonlijkheidsdimensies gebruikt met 15 items, afgeleid van onderzoek van Mcmanus en Furnham (2006) en Furnham et al. (2003). Er is gekozen voor deze items omdat het een beknopte set is die de bevraaglast beperkt en ze eerder gevalideerd zijn op een grote sample (zie ook Credé et al, 2012).

Studenten konden per persoonlijkheidsdimensie drie items beantwoorden op een schaal van ' 1 = helemaal mee oneens' tot ' $7=$ helemaal mee eens'. De vijf persoonlijkheidsdimensies zijn: Neuroticisme, Extraversie, Openheid voor ervaringen/ideeën, Inschikkelijkheid en Zorgvuldigheid.

Neuroticisme is gemeten met onder meer 'lk zie mijzelf als iemand die rustig blijft in gespannen situaties' en 'Ik zie mijzelf als iemand die vaak bezorgd is'. De betrouwbaarheid van deze dimensie bedraagt $a=0.72$ en is daarmee voldoende. Extraversie is gemeten met onder meer 'lk zie mijzelf als iemand die vlot en sociaal is' en 'lk zie mijzelf als iemand die gereserveerd is'. De interne betrouwbaarheid van extraversie bedraagt a $=0.75$ en is daarmee voldoende. Openheid voor ervaringen/ideeën is gemeten met onder meer'lk zie mijzelf als iemand die origineel is, nieuwe ideeën bedenkt' en 'Ik zie mijzelf als iemand die waarde hecht aan artistieke en esthetische ervaringen'. De interne betrouwbaarheid van openheid bedraagt $a=0.67$ en is daarmee voldoende. Inschikkelijkheid wordt gemeten aan de hand van items zoals 'lk zie mijzelf als iemand die zorgzaam en attent is met vrijwel iedereen' en 'lk zie mijzelf als iemand die vergevingsgezind is'. De betrouwbaarheid van deze schaal is matig $(\alpha=0.50)$. Deze schaal is echter eerder gevalideerd is met een grotere sample (Furnham et al., 2003; Mcmanus \& Furnham, 2006). Zorgvuldigheid is gemeten met onder meer' 'lk zie mijzelf als iemand die dingen doet op een efficiënte manier' en 'lk zie mijzelf als iemand die geneigd is om lui te zijn'. Ook de betrouwbaarheid van de deze schaal is matig $(\alpha=0.42)$, maar ook hiervoor geldt dat de betrouwbaarheid op een grotere eerdere sample getest is en hier valide op is geschat (Furnham et al., 2003; Mcmanus \& Furnham, 2006).

Studieresultaten van de student worden met de vragenlijsten op twee peilmomenten gemeten, namelijk het behaalde studieresultaat aan het einde van het eerste jaar van de bachelor (tijdens de nulmeting), en het behaalde resultaat aan het einde van de drie- of vierjarige bachelor (tijdens de eindmeting). Voor sommige onderwijsinstellingen worden de behaalde studieresultaten uit de studentenadministratie gehaald. Aangezien dit niet 
voor alle instellingen haalbaar was, zijn er in beide eindmetingen vragen opgenomen over behaalde cijfers in het eerste bachelor jaar, tweede, derde en vierde bachelor jaar, en de behaalde studiepunten. De behaalde cijfers van de studenten variëren tussen de 3 en 10. Ook is in de nulmeting gevraagd hoeveel studiepunten de student in het eerste jaar behaald heeft (of tot op het moment van de afname van de vragenlijst).

Tot slot is in de vragenlijsten een aantal achtergrondgegevens van de studenten bevraagd, zoals herkomst, opleidingsniveau en inkomensniveau van de ouders. Tevens zijn relevante gegevens opgevraagd over de opleiding, studievoortgang, in aanmerking komen voor een excellentieprogramma en deelname aan een excellentieprogramma. De herkomst van de student is bevraagd door de herkomst van de vader en moeder in de vragenlijst te verkrijgen. Hiervan is een variabele gemaakt waarvan studenten worden onderscheiden met tenminste één ouder met Nederlandse afkomst versus alle studenten waarvan beide ouders niet uit Nederland komen. Het opleidingsniveau van de ouders is ook gevraagd in de vragenlijst. Ondanks dat er studenten zijn met ouders uit het buitenland, zijn de opleidingsniveaus van de ouders langs de Nederlandse onderwijsclassificaties gelegd om ze op eenzelfde manier te kunnen analyseren. De variabele is als volgt gecodeerd ' $1=$ Basisonderwijs,' $2=\mathrm{LBO}, \mathrm{VMBO}, \mathrm{MAVO},{ }^{\prime} 3=\mathrm{HAVO}, \mathrm{VWO},{ }^{\prime} 4=$ $M B O$,' $5=\mathrm{HBO}^{\prime}$ en ' $6=$ WO'. Hierbij is het hoogste niveau van één van de twee ouders de leidraad. Inkomensgegevens van de ouders zijn bevraagd door huishoudinkomen in te schatten in ' $1=$ Beneden modaal', $2=$ Modaal', '3 = Boven modaal'.

\subsection{Studentenadministratiedata}

Op de universiteit van Maastricht is studentenadministratiedata opgevraagd voor meer informatie met betrekking tot de studieloopbaan van de student. Deze aanvullende informatie is vooral belangrijk over eindresultaten van de studenten. Deze data is gebruik voor een beperkt deel van de analyses met betrekking tot de effectiviteit van excellentieprogramma's. De eindmeting heeft plaatsgevonden toen studenten nog bezig waren hun laatste jaar af te ronden. Daardoor zijn gegevens zoals het behaalde scriptie cijfer, of het gemiddelde cijfer van de bachelor niet achterhaalbaar, en is de studentadministratiedata waardevol.

Van alle studenten die hebben deelgenomen aan de nulmetingen van zowel cohort 1 als cohort 2 zijn gegevens opgevraagd van de studentenadministratie. De gegevens zijn verzameld van cohort 1, die gestart zijn op de universiteit van Maastricht in het academische jaar 2015/2016, voor de jaren 2015/2016, 2016/2017 en 2017/2018. Voor het tweede cohort, dat gestart is met hun studie in $2016 / 2017$ is data van de studentadministratie opgevraagd van 2016/2017, 2017/2018 en 2018/2019. Hierdoor kan van allebei de cohorten de gehele bachelorperiode worden overzien. In totaal zijn er van 412 studenten gegevens van de studentadministratie beschikbaar die gekoppeld zijn aan de achtergrondvragenlijst. 
In de studentadministratie zijn gegevens opgevraagd over de studiegegevens van de student. De belangrijkste gegevens in de studentadministratie zijn alle vakken die de student gevolgd heeft, met het behaalde cijfer en het aantal studiepunten dat de student hiervoor verkregen heeft. Een student kan meerdere pogingen doen om het vak te halen, deze staan weergegeven in de studentadministratie als de student het vak niet gehaald heeft met NG (Niet gehaald) of $F$ (Fail). Op basis van de gegevens van alle vakken kan het gemiddelde cijfer voor de gehele bachelor geconstrueerd worden. Vakken die de student niet gehaald heeft worden niet meegenomen, het cijfer voor de tweede poging wordt dan meegenomen. Daarnaast kan specifiek het cijfer voor de scriptie gebruikt worden in de analyses. Beschrijvende statistieken voor de studentadministratie-gegevens worden weergegeven in Bijlage 3.

\subsection{Selectieoordeel en afronding excellentieprogramma}

Om de onderzoeksvraag naar de effectiviteit van de selectie te beantwoorden is bij de selecteurs opgevraagd wat hun oordeel was bij de toelating of afwijzing van studenten voor het excellentieprogramma. Ze konden hierbij de studenten als volgt scoren: 1 = 'Stellig afwijzen', 2 = 'Afwijzen, met twijfel', 3 = 'Aannemen met twijfel' en 4 = 'Stellig aannemen'.

Bij de eindmeting zijn de selecteurs opnieuw benaderd en is hen gevraagd om voor de destijds toegelaten studenten aan te geven in hoeverre zij het excellentieprogramma succesvol hebben afgerond. Ze konden hierbij de volgende antwoordoptie kiezen: $1=$ 'De student heeft het programma met succes afgerond', 2 = 'De student heeft het programma tot het einde gevolgd maar niet succesvol afgesloten (ontoereikende resultaten)', 3 = 'Nee, student is voortijdig uitgevallen uit het programma'. Beschrijvende statistieken omtrent het selectieoordeel en de succesvolle afronding worden gepresenteerd in Bijlage 4.

\subsection{Interviews met selecteurs}

Bij aanvang van het onderzoek zijn interviews gehouden met één of twee betrokkenen van elk excellentieprogramma dat deelnam aan het onderzoek. Veelal betrof het de coördinator van het programma, die tevens alleen of samen met collega's verantwoordelijk is voor de selectie van studenten die mogen deelnemen aan het excellentieprogramma. De interviews zijn gehouden aan de hand van een gestructureerde interviewleidraad. In de interviews is in hoofdlijnen in kaart gebracht hoe de werving van potentiele deelnemers aan excellentieprogramma's loopt, welke selectiecriteria en -procedures worden gehanteerd en wat de omvang van de interesse en deelname aan het programma is. $\mathrm{Na}$ de start van het tweede onderzochte cohort is nogmaals contact opgenomen met de geïnterviewden en is de beschrijving van de selectie voorgelegd die we op basis van het interview hadden gemaakt. Wanneer er inmiddels wijzigingen waren opgetreden in de selectie van studenten zijn deze in de beschrijving verwerkt. 
De informatie uit de interviews dient als context bij het onderzoek naar de effectiviteit van de selectie. Daarnaast hebben de interviews gediend als vooronderzoek om input te krijgen voor het bepalen van de vaardigheden en eigenschappen die we wilden meten bij de studenten. In een aantal interviews is bovendien een eerste opzet van de vignetten voor het vignettenonderzoek onder selecteurs uitgetest.

\subsection{Voorkeuren van selecteurs van excellentieprogramma's}

\subsubsection{Dataverzameling}

Het vignettenonderzoek is uitgezet onder selecteurs van excellentieprogramma's door heel Nederland in zowel het hoger beroepsonderwijs als op universiteiten. In totaal zijn 94 selecteurs benaderd en hebben 50 selecteurs de vragenlijst ingevuld, dit is een responspercentage van 53\%. De selecteurs zijn eind november/begin december 2017 via email benaderd met de vraag om deel te nemen aan het onderzoek, en het waar nodig door te sturen naar collega's die ook betrokken zijn bij selectieproces in excellentieprogramma's. De data is verzamend tot en met begin februari 2018. De data is op persoonsbasis, en er hebben 50 selecteurs de vragenlijst en vignetten compleet ingevuld. De vignetten zijn hypothetische CV's van studenten die solliciteren voor een plek in het excellentieprogramma van de desbetreffende selecteur. In de vragenlijst zijn 15 hypothetische vignetten uitgezet waarbij de selecteur elke keer de keuze had tussen 3 studenten met andere kenmerken, of de optie 'geen geschikte kandidaat'. Aangezien er 15 vignetten in de vragenlijst zijn opgenomen, zullen de analyses gedaan worden op 50 $* 3 * 15=2295$ cases.

De vignetten zien er als volgt uit:

Stelt u zich voor dat u tijdens de selectieprocedure van uw honoursprogramma nog één kandidaat kunt uitnodigen voor een gesprek. Hierna zullen wij u vijftien keer drie fictieve studenten voorleggen die in aanmerking komen voor een uitnodiging.

De studenten verschillen op een viertal cv-kenmerken:

- Gemiddeld cijfer afgelopen jaar: onder gemiddeld, gemiddeld, boven gemiddeld of beste $10 \%$ van de klas

- Buitenlandervaring: jaar reizen, studie/stage, geen

- Vrijwilliger: ja, nee

- Bijbaan: studie gerelateerd, niet-studie gerelateerd, geen bijbaan

Verder zijn de studenten identiek aan elkaar en komen alle studenten van het vwo/havo. Per set van drie studenten vragen wij u aan te geven welke student het meest in aanmerking komt voor een gesprek. 


\subsubsection{Variabelen}

De belangrijkste variabelen in het onderzoek van de vignetten hebben te maken met de kenmerken van de studenten waarop de keuze wordt gebaseerd. Zoals hierboven beschreven in het vignet verschillen de studenten op een viertal kenmerken, het hebben van een bijbaan, vrijwilligerswerk, buitenlandervaring en het gemiddeld cijfer. Deze kenmerken zijn gekozen omdat ze daadwerkelijk vaak op cv's van studenten genoemd worden. Ook bleek uit proefinterviews met selecteurs dat dit de kenmerken zijn waar selecteurs met name naar kijken bij het beoordelen van cv's van studenten. In bijlage 5 zijn de beschrijvende statistieken hiervoor weergegeven.

Daarnaast beschikken we ook nog over achtergrondgegevens van de selecteurs die de vragenlijst hebben ingevuld, waarbij informatie beschikbaar is over de functie van de selecteur, niveau van de opleiding waarbij ze betrokken zijn, namelijk hbo of wo, de instelling waaraan ze verbonden zijn, discipline van het excellentieprogramma, namelijk disciplinair, interdisciplinair of een combinatie hiervan, aantal excellentieprogramma's waarbij de selecteur betrokken is en de naam van de excellentieprogramma's waarbij de selecteur voornamelijk betrokken is. Daarnaast zijn er ook achtergrondkenmerken beschikbaar van het excellentieprogramma waar de selecteur voornamelijk bij betrokken is. Zo is er informatie over het academisch jaar/jaren waarin het excellentieprogramma valt, sollicitatieprocedure van het excellentieprogramma, namelijk of dit op uitnodiging of een open sollicitatie is. Ook de sollicitatie-eis is bekend, of er strikte cijfer eisen zijn, en zo ja, wat deze cijfer eis is, en of er soms wordt afgeweken van de eis en om welke reden er wordt afgeweken van de eis, bijvoorbeeld als er te weinig studenten zich hebben aangemeld. Als laatste is het maximumaantal studenten van het excellentieprogramma bekend waarbij de selecteur voornamelijk betrokken is. De beschrijvende statistieken van het vignettenonderzoek staan in Bijlage 5.

Daarnaast is er in de vragenlijst een aanvullende reeks kenmerken van studenten opgenomen en gevraagd of deze kenmerken worden gezien als 'niet aanvaardbaar' voor toelating tot excellentieprogramma's. De selecteurs werden gevraagd aan te geven bij welke scores op de bepaalde kenmerken ze nooit een student zouden aannemen. Deze 'niet aanvaardbaar' werd alleen gegeven wanneer de onaantrekkelijke score niet gecompenseerd kan worden met scores op andere kenmerken. De kenmerken betrekken steeds: (1) behorende tot top 25\% (2) gemiddelde score (3) behorende tot de laagste $25 \%$. De kenmerken waarop deze vragen gesteld zijn, zijn: denkvermogen en reflectievermogen; maatschappelijke betrokkenheid; creativiteit; doorzettingsvermogen; motivatie; communicatieve vaardigheden en als laatste sociale vaardigheden. 



\section{SELECTIE VAN STUDENTEN IN EXCELLENTIEPROGRAMMA'S}

\subsection{Inleiding}

In dit hoofdstuk wordt ingegaan op de selectie van studenten voor excellentieprogramma's. In het eerste deel van het hoofdstuk beschrijven we de selectieprocedures en -criteria van de verschillende excellentieprogramma 's die onderzocht zijn. We gaan hierbij uit van de situatie in de studiejaren 2016/17 en 2017/18, omdat studenten uit deze jaargangen hebben deelgenomen aan het onderzoek. Bij sommige programma's zijn er in deze periode van twee studiejaren veranderingen geweest in de programma's en de selectie. Waar relevant worden deze benoemd. Een gedetailleerde beschrijving van de selectieprocedures en -criteria van de verschillende instellingen is te vinden in bijlage 6 .

$\mathrm{Na}$ de afzonderlijke beschrijvingen van de programma's worden deze naast elkaar gelegd en met elkaar vergeleken. Wat zijn overeenkomsten tussen de wijzen van selectie tussen de programma's en wat zijn opvallende verschillen en hoe kunnen we de selectie typeren?

In het vervolg van het hoofdstuk wordt ingegaan op de effectiviteit van de selectie. De resultaten van de analyses van de metingen bij studenten worden besproken. In het laatste deel van dit hoofdstuk worden de resultaten van het vignettenonderzoek onder selecteurs gepresenteerd. De conclusies worden beschreven in het slothoofdstuk van dit rapport, aan de hand van de onderzoeksvragen naar de effectiviteit van de selectie voor excellentieprogramma's en de toegevoegde waarde van excellentieprogramma's voor studenten.

\subsection{Werving - en selectieprocedures en -criteria van de deelnemende excellentieprogramma's}

\subsubsection{Korte beschouwing van de werving- en selectieprocedures en -criteria}

\section{Werving en aanmelding}

Op een programma na, starten alle deelnemende excellentieprogramma's in het tweede jaar van de bacheloropleiding. Veelal in het tweede semester van het eerste jaar wordt voor het excellentieprogramma geworven en geselecteerd. De meeste van de deelnemende excellentieprogramma's hebben een combinatie van brede werving onder alle 
eerstejaars studenten en gerichte werving van studenten die als potentieel geschikte kandidaten zijn geïdentificeerd. Bij gerichte werving worden twee verschillende aanpakken gehanteerd; soms worden beide vormen ingezet. In de eerste aanpak wordt op basis van tot dan toe behaalde studieresultaten een groep studenten geselecteerd die gericht wordt gemaild of een brief ontvangt met een uitnodiging om zich aan te melden voor het excellentieprogramma. De exacte criteria voor deze groep verschillen per programma, bijvoorbeeld een minimaal cijfergemiddelde of de top $\mathrm{x} \%$ best presterende studenten van een opleiding. De tweede manier om mogelijk geschikte kandidaten te identificeren is docenten, studieloopbaanbegeleiders of mentoren te vragen om geschikte eerstejaars studenten bij het excellentieprogramma te melden zodat ook zij een persoonlijke uitnodiging kunnen ontvangen. Tevens wordt door de meeste programma's ook breed geworven door mailings aan alle eerstejaars studenten te richten, informatie op inter- of intranet te plaatsen en een vrij toegankelijke voorlichtingsbijeenkomst te organiseren.

Bij aanmelding voor het programma moeten studenten vrijwel altijd een cv en een sollicitatie- of motivatiebrief aanleveren. Vaak wordt ook gevraagd om tot dan toe behaalde studieresultaten mee te leveren. Bij de twee programma's van de HAN moeten studenten ook twee aanbevelingen van een docent en studieloopbaanbegeleider indienen. Bij het Law College van de UM wordt studenten gevraagd om aanvullende documentatie op te sturen zoals een profielwerkstuk of certificaten van deelname aan de Model United Nations of the Duke of Edinburgh's award. Bij de excellentieprogramma's van de Hanzehogeschool wordt een zelfreflectie gevraagd. 


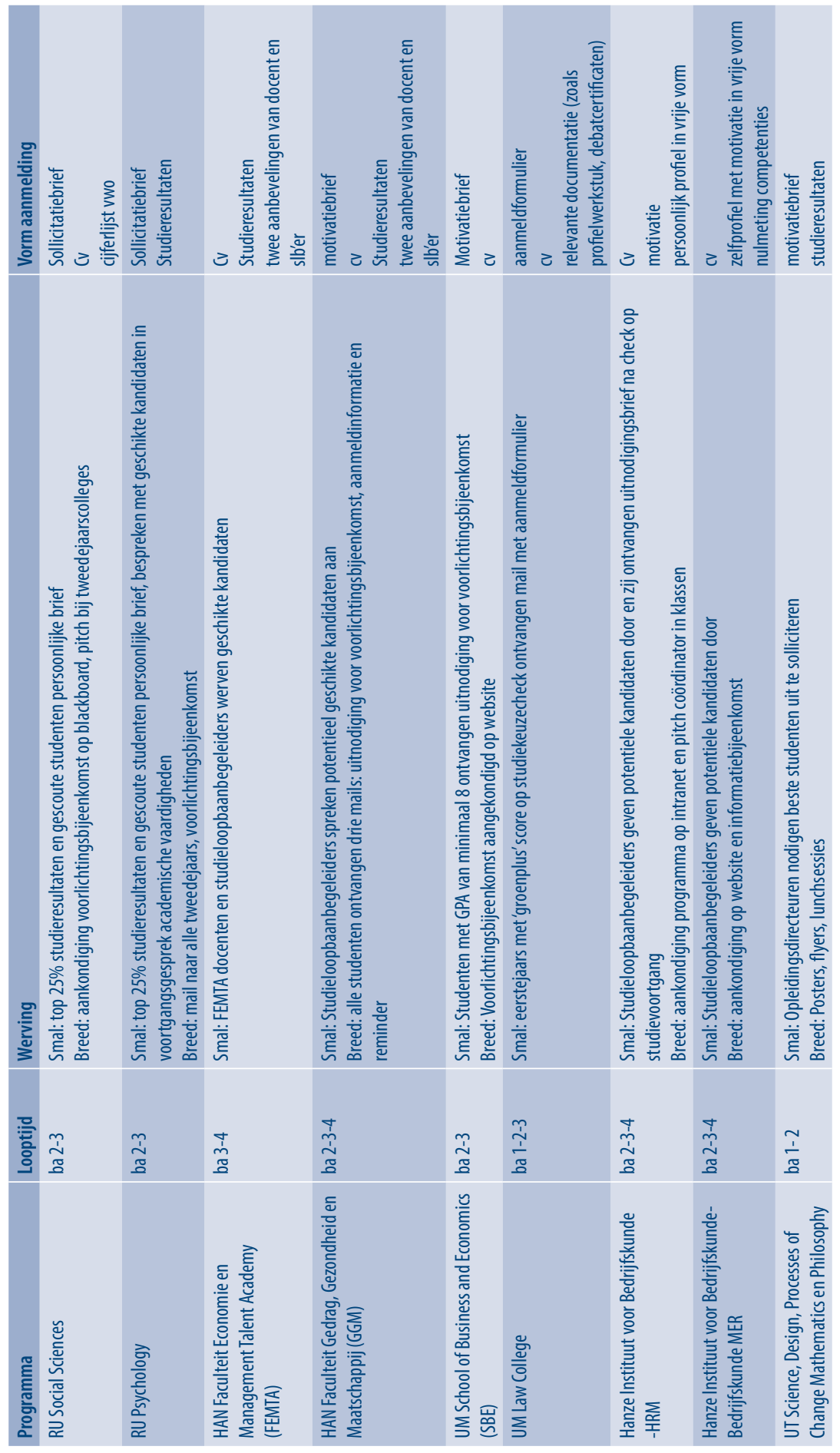




\section{Selectieprocedure}

Met uitzondering van de procedure van het SBE honoursprogramma van de UM vormt bij alle programma's de schriftelijke aanmelding de opmaat tot een mondelinge selectieprocedure die uit een of twee fasen bestaat. Bij vier van de overige acht deelnemende programma's wordt geselecteerd op basis van een of twee individuele gesprekken met de student. Bij één programma vinden de gesprekken met tweetallen studenten plaats, bij één programma worden er tijdens een gezamenlijke assessmentmiddag korte individuele gesprekken gepland en bij een programma zijn er geen individuele gesprekken, maar een groepsassessmentmiddag. Bij een programma is er echt sprake van twee opeenvolgende selectierondes en gaan individuele gesprekken vooraf aan een groepsassessment. Selectie alleen op basis van de schriftelijke aanmelding gebeurt zoals gezegd alleen bij UM SBE. Bij andere programma's is selectie op basis van de schriftelijke aanmelding vaak een theoretische mogelijkheid: het kan wel, maar gebeurt zelden of nooit. Achterliggende reden is vaak dat het aantal aanmeldingen niet of nauwelijks het aantal beschikbare plaatsen overstijgt en selecteurs de studenten het voordeel van de twijfel willen gunnen. Echter ook wanneer selectie in de praktijk niet of weinig leidt tot afwijzingen, wordt het door de programma's wel van belang geacht dat er een selectieprocedure is, omdat selectiviteit onderdeel uitmaakt van het karakter van de excellentieprogramma's. 


\begin{tabular}{|c|c|c|c|c|c|c|c|c|c|}
\hline & 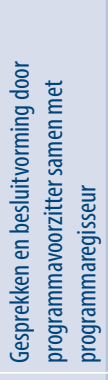 & 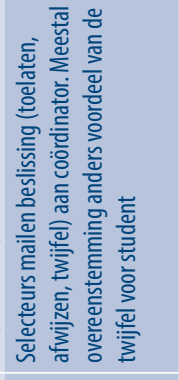 & 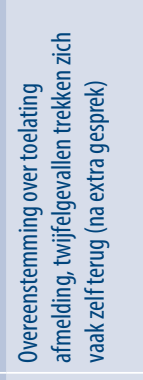 & 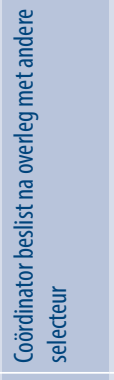 & 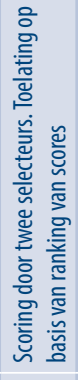 & 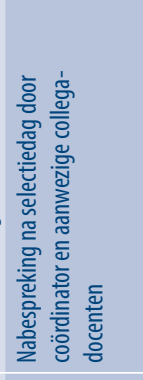 & 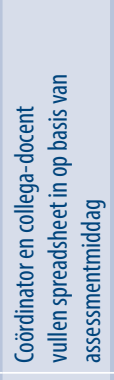 & 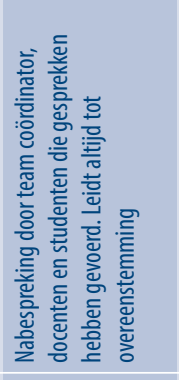 & 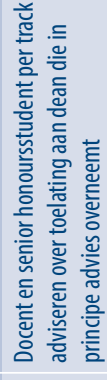 \\
\hline & 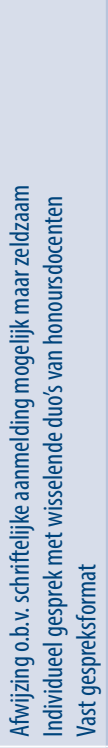 & 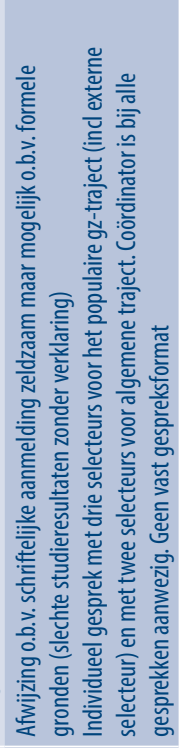 & 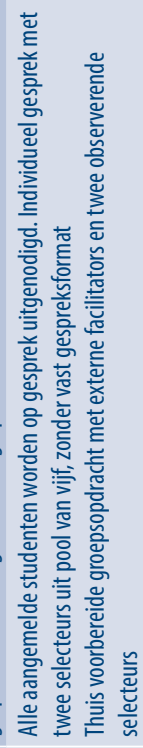 & 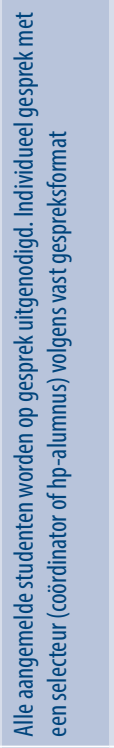 & 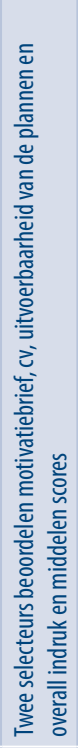 & 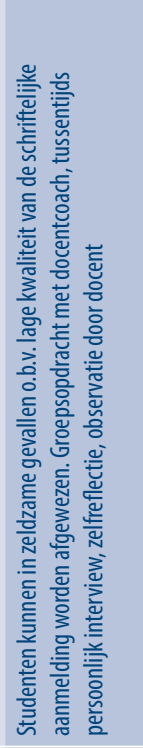 & 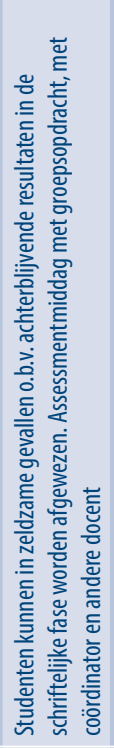 & 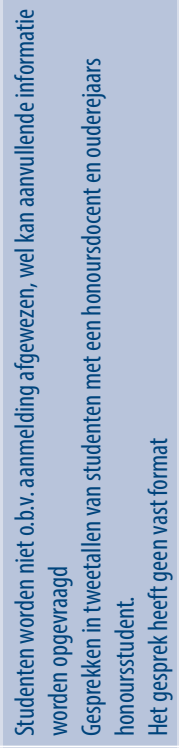 & 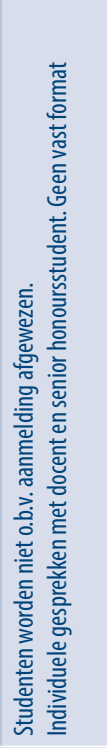 \\
\hline & 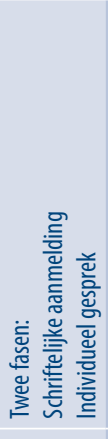 & 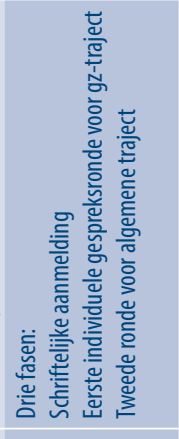 & 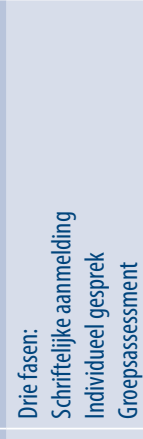 & 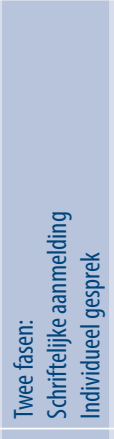 & 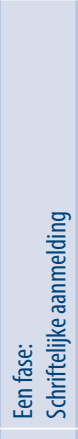 & 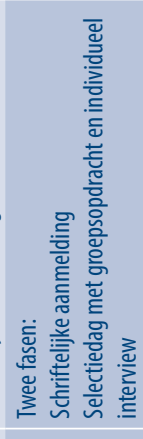 & 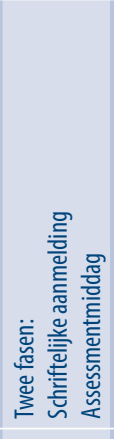 & 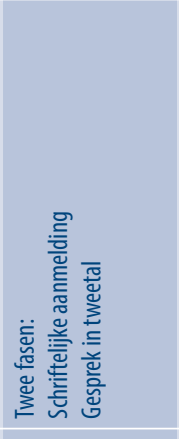 & 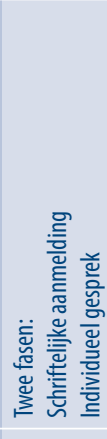 \\
\hline & 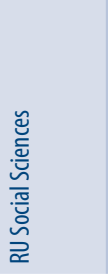 & 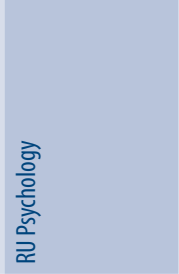 & 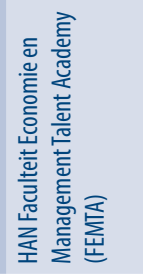 & 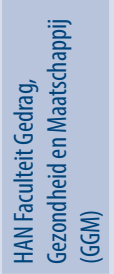 & 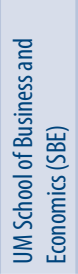 & 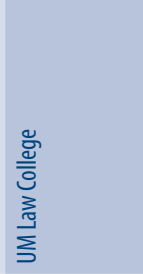 & 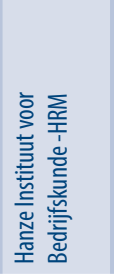 & 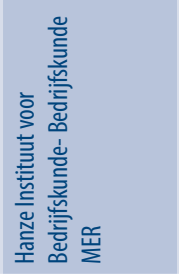 & 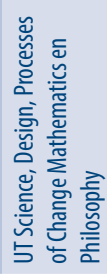 \\
\hline
\end{tabular}




\section{Selectiecriteria}

Selectiecriteria met een vastgestelde norm bestaan alleen op het vlak van studievoortgang (propedeuse behaald) en studieresultaten (een minimum gemiddelde). De studieresultaten kunnen een criterium zijn op basis waarvan een voorselectie van studenten wordt gemaakt die worden uitgenodigd te solliciteren naar een plaats in het programma (zie werving). Het criterium wordt echter in de regel niet hard gehanteerd. Studenten die niet voldoen aan de resultaatnorm staat het vrij te solliciteren en wanneer zij een verklaring hebben voor hun achterblijvende studieresultaten en/of op andere manieren hun geschiktheid voor het excellentieprogramma kunnen aantonen, kunnen ze alsnog toegelaten worden.

Voor andere selectiecriteria die worden gehanteerd zijn geen normen vastgesteld. Het betreft in de regel eigenschappen en competenties die men lastig te objectiveren en kwantificeren acht. Bij de meeste programma's zijn de inhoudelijke criteria beschreven in een profiel, reglement of beleidsstuk. Bij slechts enkele programma's worden de criteria ook concreet gehanteerd bij de selectieprocedure in de vorm van een gestandaardiseerd scoreformulier, zodat door elke beoordelaar en in elke procedure expliciet dezelfde criteria aan bod komen.

Naast een eventuele kwantitatieve eis ten aanzien van de studieresultaten, komen de volgende eigenschappen of competenties meermaals terug in de vorm van criteria:

- Motivatie, ambitie, pro-activiteit, enthousiasme

- Creativiteit, vernieuwingsgerichtheid, buiten gebaande paden willen treden

- Samenwerkingsgerichtheid, sociale en communicatievaardigheden

- Zelfstandigheid, volwassenheid, juiste inschatting programma en tijdsbesteding, uitvoerbaarheid van plannen

- Kritisch denkvermogen

- Maatschappelijke betrokkenheid

- Reflectievermogen

- Het programma doelgericht willen inzetten voor persoonlijk en/of professionele ontwikkeling, interesse in zelfontwikkeling 


\begin{tabular}{|c|c|c|}
\hline Programma & $\begin{array}{l}\text { Selectiecriteria met } \\
\text { norm }\end{array}$ & Vrij geformuleerde selectiecriteria \\
\hline RU Social Sciences & $\begin{array}{l}\text { Minimaal } 7 \text { en } \\
\text { propedeuse behaald }\end{array}$ & $\begin{array}{l}\text { Profiel honoursstudent is beschreven. Eigenschappen: motivatie, } \\
\text { ambitie, enthousiasme, zelfstandigheid, kritisch denken, creativiteit, } \\
\text { uniciteit. Mix gezocht i.v.m. groepsdynamiek. }\end{array}$ \\
\hline RU Psychology & $\begin{array}{l}\text { Propedeuse behaald } \\
\text { en minimaal } 7,5 \\
\text { (uitzonderingen } \\
\text { mogelijk) }\end{array}$ & $\begin{array}{l}\text { In gesprekken gz-variant let men op: inschatting tijdsbesteding, } \\
\text { correspondentie tussen verwachtingen en aanbod, juiste } \\
\text { persoonlijkheid en communicatieve vaardigheden heeft om in een } \\
\text { gz-instelling te functioneren, beleidsmatige interesse, voldoende } \\
\text { volwassenheid } \\
\text { Algemene variant: inhoudelijke interesse, onderzoek willen doen, } \\
\text { studieresultaten, inschatting tijdsbesteding en zelfstandigheid. } \\
\text { Criteria liggen niet vast. }\end{array}$ \\
\hline $\begin{array}{l}\text { HAN Faculteit Economie en } \\
\text { Management Talent Academy } \\
\text { (FEMTA) }\end{array}$ & & $\begin{array}{l}\text { Criteria zijn goede studievoortgang en zes inhoudelijke criteria, } \\
\text { vastgelegd in model voor intakegesprek. } \\
\text { In gesprek en assessment wordt gelet op: authenticiteit, motivatie, } \\
\text { inhoudelijkheid, risicobereidheid, samenwerkingsgerichtheid, kritisch } \\
\text { denkvermogen en creativiteit, organiserend vermogen. Verder ook: } \\
\text { communicatieve vaardigheden, rol in groep, zelfreflectie. }\end{array}$ \\
\hline $\begin{array}{l}\text { HAN Faculteit Gedrag, } \\
\text { Gezondheid en Maatschappij } \\
\text { (GGM) }\end{array}$ & $\begin{array}{l}7 \text { gemiddeld en } \\
\text { propedeuse behaald }\end{array}$ & $\begin{array}{l}\text { In gesprek worden volgende onderdelen besproken en gescoord op } \\
\text { scoreformulier (++ tot --): achtergrond (opleiding, competenties, } \\
\text { talenten), motivatie, capaciteiten, gelegenheid (hobby's, sport, } \\
\text { werk, sociaal), wederzijdse verwachtingen en vertrouwen in eigen } \\
\text { studiesucces. Men zoekt studenten die kritisch zijn, coherent, } \\
\text { langetermijninzicht hebben, volwassenheid tonen en het programma } \\
\text { inzetten om een betere professional te worden. }\end{array}$ \\
\hline $\begin{array}{l}\text { UM School of Business and } \\
\text { Economics (SBE) }\end{array}$ & Minimaal GPA van 8 & $\begin{array}{l}\text { Twee selecteurs kennen punten toe voor motivatiebrief, } \\
\text { cv, uitvoerbaarheid plannen en overall indruk. Deze scores } \\
\text { worden gemiddeld en daarna met GPA gemiddeld (fifty-fifty). } \\
\text { Aandachtspunten in beoordeling brief en cv: engagement, ambitie } \\
\text { en creativiteit. }\end{array}$ \\
\hline UM Law College & $\begin{array}{l}\text { Vaste criteria en norm } \\
\text { voor uitnodiging 0.b.v. } \\
\text { studiekeuzecheck ( } 0 . \text {.a. } \\
\text { cijfers vooropleiding) }\end{array}$ & $\begin{array}{l}\text { Op selectiedag wordt scoreformulier met zes eigenschappen } \\
\text { gebruikt. Op deze dag wordt gekeken naar academische en sociale } \\
\text { vaardigheden, ambitie, potentie en interesse in zelfontwikkeling. }\end{array}$ \\
\hline $\begin{array}{l}\text { Hanze Instituut voor } \\
\text { Bedrijfskunde -HRM }\end{array}$ & & $\begin{array}{l}\text { Zes competenties beschreven in beleidsstuk vormen } \\
\text { excellentieprofiel. Goede studievoortgang is een criterium maar } \\
\text { zonder vaste norm. } \\
\text { Na assessmentmiddag worden studenten gescoord met goed, } \\
\text { voldoende of twijfel op basis van: vernieuwingsgerichtheid } \\
\text { (creativiteit), samenwerkingsgerichtheid en interactief } \\
\text { leervermogen. Verder zijn belangrijk: reflectiviteit en } \\
\text { communicatieve vaardigheden. }\end{array}$ \\
\hline $\begin{array}{l}\text { Hanze Instituut voor } \\
\text { Bedrijfskunde- Bedrijfskunde } \\
\text { MER }\end{array}$ & $\begin{array}{l}\text { Propedeuse moet bijna } \\
\text { gehaald zijn op moment } \\
\text { van selectie }\end{array}$ & $\begin{array}{l}\text { Uitgangspunt is het excellentieprofiel dat bestaat uit de } \\
\text { competenties: vernieuwingsgerichtheid, intrapreneurship, } \\
\text { leiderschap, samenwerkingsgerichtheid, duurzaamheidsgerichtheid } \\
\text { en interactief leervermogen. } \\
\text { In de gesprekken wordt gelet op proactiviteit, motivatie en een } \\
\text { persoonlijk doel met het honoursprogramma hebben. }\end{array}$ \\
\hline $\begin{array}{l}\text { UT Science, Design, Processes } \\
\text { of Change Mathematics en } \\
\text { Philosophy }\end{array}$ & $\begin{array}{l}\text { Nominale } \\
\text { studievoortgang }\end{array}$ & $\begin{array}{l}\text { Criteria staan kort beschreven in het programmareglement: } \\
\text { motivatie, ondernemendheid, goede studieresultaten, buiten de } \\
\text { gebaande paden treden en maatschappelijke relevantie nastreven. }\end{array}$ \\
\hline
\end{tabular}




\subsection{Effectiviteit van selectie}

\subsubsection{Inleiding}

In deze paragraaf gaan we in op de vraag naar de effectiviteit van selectie. We benaderen de vraag naar de effectiviteit van de selectie op twee manieren. Ten eerste kijken we naar factoren die de kans op deelname aan een excellentieprogramma mogelijkerwijs bepalen; vervolgens bestuderen we factoren die de kans op een succesvolle afronding van het excellentieprogramma voorspellen.

Bij de meeste programma's wordt in de selectie gekeken naar de studieresultaten die studenten in het eerste jaar hebben behaald. Daarom kijken we in hoeverre de eerdere behaalde studieresultaten voorspellend zijn voor de kans op deelname aan een excellentieprogramma. Daarnaast analyseren we het effect van de resultaten van de testen die aanvullend vanuit het onderzoek zijn voorgelegd aan de studenten, namelijk de Watson-Glaser test voor kritisch denken en de Alternate Uses Test voor creativiteit. In hoeverre zijn de scores die studenten halen op de vaardigheden kritisch denken en creativiteit zoals door deze twee testen gemeten voorspellend voor hun kans op deelname aan een excellentieprogramma?

In deze analyses wordt een vergelijking gemaakt tussen de groep studenten die deelneemt aan een excellentieprogramma en de groep studenten die niet deelneemt aan een excellentieprogramma. Binnen de groep niet-deelnemers maken we onderscheid tussen studenten die hebben aangegeven dat ze niet in aanmerking kwamen om een excellentieprogramma te gaan doen en studenten die aangaven dat ze in principe wel in aanmerking kwamen, maar ervoor hebben gekozen zich niet voor het excellentieprogramma aan te melden. Van deze laatste groep kunnen we immers verwachten dat zij, in ieder geval wat betreft de formele eisen van de programma's, het meest lijken op de groep die wel deelneemt waardoor deze vergelijking het meeste inzicht kan geven in de factoren waarop studenten die wel of niet deelnemen aan een excellentieprogramma zich van elkaar onderscheiden.

Vervolgens wordt binnen de groep studenten die deelnemen aan een excellentieprogramma een vergelijking gemaakt tussen de studenten die het programma wel en niet succesvol hebben afgerond. We kijken hierbij weer naar dezelfde voorspellers, namelijk eerder behaalde studieresultaten en de scores op de testen voor kritisch denken en creativiteit en voegen een vierde verklarende factor toe, namelijk het oordeel van de selecteur bij toelating tot het programma. We hebben de selecteurs gevraagd naar hun oordelen over studenten bij de toelating tot het excellentieprogramma, waarbij ze onderscheid konden maken tussen 'zeker toegelaten' en 'toegelaten met twijfel'. In hoeverre is dit oordeel voorspellend voor de kans op succesvolle afronding van het excellentieprogramma?

De analyses naar de kans op deelname aan een excellentieprogramma (wel deelname/geen deelname niet aanmerking gekomen/geen deelname wel in aanmerking 
gekomen) zijn uitgevoerd met behulp van een multinomiaal logistisch regressiemodel; voor de analyses naar de kans op succesvolle afronding (wel/niet het excellentieprogramma succesvol afgerond) is een logistisch regressiemodel gebruikt. In de regressiemodellen wordt stap voor stap een aantal kenmerken van de studenten als controlevariabelen toegevoegd. Hiermee kan worden nagegaan in hoeverre de onderzochte voorspellers (studieresultaten, kritisch denken, creativiteit en oordeel van de selecteur) daadwerkelijk voorspellend zijn voor deelname aan en/of succesvolle afronding van het programma, en in hoeverre andere kenmerken van studenten een rol spelen.

Wanneer een variabele een significant positief effect laat zien, betekent dit dat deze indicator de kans op deelname aan, respectievelijk succesvolle afronding van een excellentieprogramma vergroot. Een significant negatief effect duidt op een kleinere kans op deelname.

\subsubsection{Voorspellers voor de kans op deelname aan een excellentieprogramma}

De tabellen 4 en 5 tonen de resultaten van de multinomiaal logistische regressiemodellen naar de voorspellende waarde van de scores op de test voor kritisch denken voor de kans op deelname aan een excellentieprogramma, gebaseerd op een vergelijking tussen deelnemers en niet-deelnemers die ook niet aanmerking kwamen voor het programma (tabel 4) en die tussen deelnemers en niet-deelnemers die wel in aanmerking kwamen voor het programma (tabel 5).

Tabel 4 laat zien dat een hogere score op de test voor kritisch denken samengaat met een grotere kans op deelname aan een excellentieprogramma als we de deelnemers en niet-deelnemers, die ook niet in aanmerking kwamen voor deelname, vergelijken. Dit effect houdt stand als er controlevariabelen worden opgenomen (zie de modellen $\mathrm{M}_{2}$ en $\mathrm{M}_{3}$ ). Model M2 laat verder zien dat de kans op deelname aan een excellentieprogramma kleiner is voor studenten met ouders die een lagere of middelbare beroepsopleiding hebben gevolgd (in vergelijking met academisch opgeleide ouders) en groter voor studenten van wie de ouders bovenmodaal verdienen. Model $\mathrm{M}_{3}$ toont dat (zowel intrinsiek als extrinsiek) gemotiveerde studenten een grote kans op deelname hebben, evenals studenten die zorgvuldig en zelfeffectief zijn. Extraverte studenten hebben daarentegen een lagere kans op deelname aan een excellentieprogramma.

In Tabel 5 wordt zoals gezegd opnieuw gekeken naar de voorspellende waarde van de vaardigheid kritisch denken voor deelname aan een excellentieprogramma, maar nu op basis van een analyse van de gehele groep studenten die in aanmerking kwam voor een excellentieprogramma, van wie een deel daadwerkelijk het programma is gaan doen en een ander deel niet. In deze tabel wordt meteen duidelijk dat er nauwelijks nog significante verschillen zijn tussen deze twee groepen. De modellen laten zien dat alleen een hogere mate van (intrinsieke en extrinsieke) motivatie de kans op deelname significant vergroot. 
In de tabellen 6 en 7 is de voorspellende waarde van kritisch denken op de kans op deelname aan een excellentieprogramma (voor beide vergelijkingsgroepen) opnieuw gepresenteerd, maar nu zonder weergave van de effecten van de overige variabelen. Soortgelijke modellen zijn geschat voor het vaststellen van de voorspellende waarde van creativiteit en studieresultaten behaald in het eerste leerjaar. Eveneens is een model geschat waarin de kenmerken kritisch denken, creativiteit en studieresultaten in het eerste leerjaar tegelijkertijd zijn opgenomen. Vergelijking van deze modellen maakt het mogelijk het relatieve belang van deze drie kenmerken te beschouwen.

Tabel 6 laat zien dat de kans op deelname aan een excellentieprogramma (tegenover geen deelname en niet in aanmerking gekomen) groter is naarmate studenten betere studieresultaten behalen in het eerste leerjaar. Dit effect blijf bestaan wanneer controlevariabelen in het regressiemodel worden opgenomen (modellen $\mathrm{M}_{2}$ en $\mathrm{M}_{3}$ ). De voorspellende waarde van studieresultaten voor deelname aan een excellentieprogramma is geen verrassende uitkomst, aangezien een deel van de excellentieprogramma's eerder behaalde studieresultaten als een selectiecriterium voor toelating hanteert. Creativiteit heeft slechts een marginale invloed op de kans op deelname aan een excellentieprogramma. Dit effect verdwijnt wanneer alle drie de onderzochte voorspellers tegelijk in het regressiemodel worden opgenomen. De effecten van kritisch denken en studieresultaten blijven wel significant.

Tabel 7 is vergelijkbaar met tabel 6, maar toont de resultaten van de kans op deelname aan een excellentieprogramma ten opzichte van geen deelname voor degenen die wel in aanmerking kwamen. Kritisch denken en creativiteit hebben in sommige modellen een marginaal significante invloed op de kans op deelname, maar wanneer hun onderlinge samenhang, evenals die met de studieresultaten in het eerste leerjaar, in ogenschouw wordt genomen, dan blijkt geen van de drie kenmerken een rol van betekenis te spelen bij de kans op deelname aan een excellentieprogramma.

In de tabellen 8 en 9 worden tot slot de resultaten van dezelfde analyses getoond, maar uitgesplitst naar hbo en wo. Uit tabel 8 , met daarin de resultaten van de analyses van deelname ten opzichte van geen deelname en niet aanmerking gekomen, blijkt dat in het eindmodel, waarin alle drie de mogelijke voorspellers en de controlekenmerken zijn opgenomen, de studieresultaten behaald in het eerste leerjaar en de vaardigheid kritisch denken een positief effect hebben op de kans op deelname aan een excellentieprogramma. Dit geldt zowel voor het hbo als voor het wo. Voor wat betreft de vergelijking met niet-deelnemers die wel in aanmerking kwamen voor deelname aan een excellentieprogramma (zie tabel 9) wordt geconstateerd dat voor het hbo alle drie de kenmerken een positieve invloed hebben, terwijl voor het wo geldt dat geen enkel kenmerk voorspellend is voor deelname aan een excellentieprogramma.

\subsubsection{Voorspellers voor de kans op succesvolle afronding van een excellentieprogramma} In deze paragraaf worden de resultaten besproken van de analyses naar de voorspellers van een succesvolle afronding van een excellentieprogramma. In tabel 10 worden logis- 
tische regressiemodellen getoond voor de rol die de vaardigheid kritisch denken speelt bij de kans op succesvolle afronding van een excellentieprogramma. We kijken, net als bij de analyses in de vorige paragraaf, achtereenvolgens naar de invloed van achtergrondkenmerken (zoals afkomst, taal, opleiding en inkomen van ouders), motivatiekenmerken en persoonlijkheidskenmerken van studenten. Nevenactiviteiten worden in deze analyses tot slot als extra controlevariabelen toegevoegd. Uit deze tabel komt naar voren dat kritisch denken geen significante voorspeller is voor het wel of niet succesvol afronden van een excellentieprogramma. Ook de invloed van andere kenmerken is zeer gering; alleen studenten met ouders die havo of vwo als hoogst bereikte opleidingsniveau hebben en studenten die risicopreferent zijn, hebben een ietwat grotere kans op een succesvolle afronding van een excellentieprogramma. De enige factor van betekenis is het aantal uren betaald werk in de week: studenten die meer uren werken naast hun studie hebben een significant kleinere kans op het succesvol afronden van een excellentieprogramma.

In tabel 11 wordt de invloed van kritisch denken op de kans op een succesvolle afronding van een excellentieprogramma nogmaals getoond, maar nu zonder de effecten van de controlevariabelen te presenteren. Ook de resultaten van de rol die de vaardigheid creativiteit, de studieresultaten in het eerste leerjaar en het oordeel van de selecteur (zeker of met twijfel toegelaten) mogelijkerwijs spelen bij de kans op succesvolle afronding staan in deze tabel samengevat. Uit de tabel blijkt dat geen enkele van deze vier kenmerken een significante invloed heeft op de kans op succesvolle afronding van een excellentieprogramma.

In tabel 12 worden de resultaten tot slot uitgesplitst naar hbo en wo. Voor het hbo laten de resultaten zien dat kritisch denken een rol speelt: hbo-studenten die hoger scoren op de vaardigheid kritisch denken hebben, verrassend genoeg, een kleinere kans op succesvolle afronding van een excellentieprogramma. 
TABEL 4 Multinomiaal logistisch regressiemodel van de kans op deelname aan een excellentieprogramma

\begin{tabular}{|c|c|c|c|c|c|c|}
\hline \multirow{2}{*}{$\begin{array}{l}\text { Deelname versus geen deelname, NIET in aanmerking gekomen } \\
\text { Intercept }\end{array}$} & \multicolumn{2}{|l|}{$M 1^{\mathrm{a}}$} & \multicolumn{2}{|l|}{$M 2^{\mathrm{a}}$} & \multicolumn{2}{|c|}{$M 3^{\mathrm{a}}$} \\
\hline & $-0,352$ & $\sim$ & $-0,504$ & * & $-7,303$ & *** \\
\hline Kritisch denken & 0,018 & *** & 0,015 & *** & 0,020 & *** \\
\hline \multicolumn{7}{|l|}{ Achtergrondkenmerken student } \\
\hline Ten minste één ouder van Nederlandse afkomst & & & 0,365 & & & \\
\hline Nederlandse taal & & & 0,182 & & & \\
\hline \multicolumn{7}{|l|}{ Hoogste opleiding ouders } \\
\hline Basisonderwijs (ref.=W0) & & & 1,836 & & & \\
\hline LBO, VMBO, MAVO (ref.=WO) & & & $-1,123$ & ** & & \\
\hline HAVO, VWO (ref.=WO) & & & 0,125 & & & \\
\hline MBO (ref.=W0) & & & $-0,719$ & * & & \\
\hline HBO (ref.=W0) & & & $-0,277$ & & & \\
\hline \multicolumn{7}{|l|}{ Inkomen ouders } \\
\hline Beneden modaal (ref.= Modaal) & & & 0,226 & & & \\
\hline Boven modaal (ref.=Modaal) & & & 0,370 & * & & \\
\hline \multicolumn{7}{|l|}{ Motivatiekenmerken student } \\
\hline Intrinsieke motivatie & & & & & 0,578 & *** \\
\hline Extrinsieke motivatie & & & & & 0,628 & *** \\
\hline Consistentie van inzet & & & & & $-0,100$ & \\
\hline Doorzettingsvermogen & & & & & $-0,106$ & \\
\hline \multicolumn{7}{|l|}{ Persoonlijkheidskenmerken student } \\
\hline Neuroticisme & & & & & 0,020 & \\
\hline Extraversie & & & & & $-0,266$ & * \\
\hline Openheid & & & & & $-0,032$ & \\
\hline Inschikkelijkheid & & & & & $-0,050$ & \\
\hline Zorgvuldigheid & & & & & 0,659 & *** \\
\hline Zelfeffectiviteit & & & & & 0,505 & $\sim$ \\
\hline Risicopreferentie & & & & & 0,015 & \\
\hline Model Chi2 & 77,015 & *** & 110,026 & *** & 183,692 & *** \\
\hline Df & 12 & & 30 & & 34 & \\
\hline $\mathrm{N}$ & 846 & & 846 & & 846 & \\
\hline
\end{tabular}

$\sim p<0,1 ;{ }^{*}<<0,05 ;{ }^{* *} p<0,01 ;{ }^{* * *} p<0,001$

${ }^{a}$ gecontroleerd voor instelling en cohort 
TABEL 5 Multinomiaal logistisch regressiemodel van de kans op deelname aan een excellentieprogramma

\begin{tabular}{|c|c|c|c|c|c|c|}
\hline \multirow{2}{*}{$\begin{array}{l}\text { Deelname versus geen deelname, WEL in aanmerking gekomen } \\
\text { Intercept }\end{array}$} & \multicolumn{2}{|l|}{ M1 } & \multicolumn{2}{|l|}{$\mathrm{M}^{\mathrm{a}}$} & \multicolumn{2}{|l|}{$M 3^{a}$} \\
\hline & 1,023 & $* * *$ & 0,848 & * & $-4,104$ & ** \\
\hline Kritisch denken & 0,006 & & 0,002 & & 0,007 & $\sim$ \\
\hline \multicolumn{7}{|l|}{ Achtergrondkenmerken student } \\
\hline Ten minste één ouder van Nederlandse afkomst & & & 0,817 & & & \\
\hline Nederlandse taal & & & $-0,309$ & & & \\
\hline \multicolumn{7}{|l|}{ Hoogste opleiding ouders } \\
\hline Basisonderwijs (ref.=W0) & & & $-0,260$ & & & \\
\hline LBO, VMBO, MAVO (ref.=WO) & & & $-0,132$ & & & \\
\hline HAVO, VWO (ref.=W0) & & & $-0,167$ & & & \\
\hline MBO (ref.=W0) & & & $-0,203$ & & & \\
\hline HBO (ref.=WO) & & & $-0,075$ & & & \\
\hline \multicolumn{7}{|l|}{ Inkomen ouders } \\
\hline Beneden modaal (ref.= Modaal) & & & 0,169 & & & \\
\hline Boven modaal (ref.= Modaal) & & & 0,276 & & & \\
\hline \multicolumn{7}{|l|}{ Motivatiekenmerken student } \\
\hline Intrinsieke motivatie & & & & & 0,396 & $\sim$ \\
\hline Extrinsieke motivatie & & & & & 0,498 & $* * *$ \\
\hline Consistentie van inzet & & & & & 0,036 & \\
\hline Doorzettingsvermogen & & & & & $-0,048$ & \\
\hline \multicolumn{7}{|l|}{ Persoonlijkheidskenmerken student } \\
\hline Neuroticisme & & & & & $-0,011$ & \\
\hline Extraversie & & & & & $-0,188$ & \\
\hline Openheid & & & & & 0,121 & \\
\hline Inschikkelijkheid & & & & & 0,042 & \\
\hline Zorgvuldigheid & & & & & 0,184 & \\
\hline Zelffeffectiviteit & & & & & 0,188 & \\
\hline Risicopreferentie & & & & & 0,077 & \\
\hline Model Chi2 & 77,015 & $* * *$ & 110,026 & *** & 183,692 & *** \\
\hline Df & 12 & & 30 & & 34 & \\
\hline $\mathrm{N}$ & 846 & & 846 & & 846 & \\
\hline
\end{tabular}

$\sim p<0,1 ;{ }^{*} p<0,05 ;{ }^{* *} p<0,01 ;{ }^{* * *} p<0,001$

a gecontroleerd voor instelling en cohort 
TABEL 6 Multinomiaal logistisch regressiemodel van de kans op deelname aan een excellentieprogramma

\begin{tabular}{|c|c|c|c|c|c|c|}
\hline Deelname versus geen deelname, NIET in aanmerking gekomen & \multicolumn{2}{|c|}{ M1 } & \multicolumn{2}{|l|}{ M2 } & \multicolumn{2}{|l|}{ M3 } \\
\hline Kritisch denken & 0,018 & *** & 0,015 & *** & 0,020 & $* * *$ \\
\hline Model Chi2 & 77,015 & *** & 110,026 & *** & 183,692 & $* * *$ \\
\hline Df & 12 & & 30 & & 34 & \\
\hline N & 846 & & 846 & & 846 & \\
\hline Creativiteit & 0,026 & $\sim$ & 0,013 & & 0,029 & $\sim$ \\
\hline Model Chi2 & 42,425 & *** & 88,842 & *** & 152,635 & *** \\
\hline Df & 12 & & 30 & & 34 & \\
\hline N & 846 & & 846 & & 846 & \\
\hline Gemiddeld cijfer eerste jaar & 1,946 & $* * *$ & 2,022 & $* * *$ & 1,859 & $* * *$ \\
\hline Model Chi2 & 188,344 & $* * *$ & 235,514 & $* * *$ & 270,835 & $* * *$ \\
\hline Df & 12 & & 30 & & 34 & \\
\hline N & 846 & & 846 & & 846 & \\
\hline Kritisch denken & 0,016 & $* * *$ & 0,011 & ** & 0,016 & $* * *$ \\
\hline Creativiteit & $-0,001$ & & $-0,004$ & & 0,006 & \\
\hline Gemiddeld cijfer eerste jaar & 1,891 & $* * *$ & 1,969 & $* * *$ & 1,807 & $* * *$ \\
\hline Model Chi2 & 213,606 & $* * *$ & 246,351 & $* * *$ & 294,784 & $* * *$ \\
\hline Df & 16 & & 34 & & 38 & \\
\hline N & 846 & & 846 & & 846 & \\
\hline
\end{tabular}

$\sim p<0,1 ;{ }^{*} p<0,05 ;{ }^{* *} p<0,01 ;{ }^{* * *} p<0,001$ 
TABEL 7 Multinomiaal logistisch regressiemodel van de kans op deelname aan een excellentieprogramma

\begin{tabular}{|c|c|c|c|c|c|c|}
\hline Deelname versus geen deelname, WEL in aanmerking gekomen & M1 & & M2 & & M3 & \\
\hline Kritisch denken & 0,006 & & 0,002 & & 0,007 & $\sim$ \\
\hline Model Chi2 & 77,015 & *** & 110,026 & *** & 183,692 & *** \\
\hline Df & 12 & & 30 & & 34 & \\
\hline N & 846 & & 846 & & 846 & \\
\hline Creativiteit & 0,035 & $\sim$ & 0,025 & & 0,034 & $\sim$ \\
\hline Model Chi2 & 42,425 & *** & 88,842 & *** & 152,635 & *** \\
\hline Df & 12 & & 30 & & 34 & \\
\hline N & 846 & & 846 & & 846 & \\
\hline Gemiddeld cijfer eerste jaar & 0,357 & & 0,381 & & 0,317 & \\
\hline Model Chi2 & 188,344 & *** & 235,514 & $* * *$ & 270,835 & *** \\
\hline Df & 12 & & 30 & & 34 & \\
\hline N & 846 & & 846 & & 846 & \\
\hline Kritisch denkenz & 0,004 & & 0,000 & & 0,005 & \\
\hline Creativiteit & 0,026 & & 0,023 & & 0,028 & \\
\hline Gemiddeld cijfer eerste jaar & 0,320 & & 0,374 & & 0,271 & \\
\hline Model Chi2 & 213,606 & *** & 246,351 & *** & 294,784 & *** \\
\hline Df & 16 & & 34 & & 38 & \\
\hline N & 846 & & 846 & & 846 & \\
\hline
\end{tabular}

$\sim p<0,1 ;{ }^{*} p<0,05 ;{ }^{* *} p<0,01 ;{ }^{* * *} p<0,001$ 
TABEL 8 Multinomiaal logistisch regressiemodel van de kans op deelname aan een excellentieprogramma, naar hbo en wo

\begin{tabular}{|c|c|c|c|c|c|c|}
\hline Deelname versus geen deelname, NIET in aanmerking gekomen & M1 & & M2 & & M3 & \\
\hline तDV & & & & & & \\
\hline Kritisch denken & 0,019 & * & 0,018 & * & 0,021 & * \\
\hline Model Chi2 & 16,850 & ** & 37,661 & * & 70,094 & *** \\
\hline Df & 6 & & 24 & & 28 & \\
\hline $\mathrm{N}$ & 216 & & 216 & & 216 & \\
\hline Creativiteit & 0,038 & & 0,033 & & 0,060 & $\sim$ \\
\hline Model Chi2 & 11,202 & $\sim$ & 32,652 & & 69,599 & *** \\
\hline Df & 6 & & 24 & & 28 & \\
\hline N & 216 & & 216 & & 216 & \\
\hline Gemiddeld cijfer eerste jaar & 1,485 & $* * *$ & 1,660 & $* * *$ & 1,395 & ** \\
\hline Model Chi2 & 25,284 & *** & 49,010 & ** & 74,024 & *** \\
\hline Df & 6 & & 24 & & 28 & \\
\hline N & 216 & & 216 & & 216 & \\
\hline Kritisch denken & 0,021 & * & 0,019 & * & 0,019 & $\sim$ \\
\hline Creativiteit & 0,006 & & 0,006 & & 0,038 & \\
\hline Gemiddeld cijfer eerste jaar & 1,588 & *** & 1,727 & *** & 1,433 & ** \\
\hline Model Chi2 & 37,227 & *** & 59,128 & *** & 85,555 & *** \\
\hline Df & 10 & & 28 & & 32 & \\
\hline $\mathrm{N}$ & 216 & & 216 & & 216 & \\
\hline wo & & & & & & \\
\hline Kritisch denken & 0,018 & *** & 0,016 & *** & 0,021 & *** \\
\hline Model Chi2 & 62,921 & *** & 104,197 & *** & 146,025 & *** \\
\hline Df & 8 & & 26 & & 30 & \\
\hline N & 630 & & 630 & & 630 & \\
\hline Creativiteit & 0,020 & & 0,005 & & 0,022 & \\
\hline Model Chi2 & 31,880 & *** & 81,976 & *** & 113,237 & *** \\
\hline Df & 8 & & 26 & & 30 & \\
\hline $\mathrm{N}$ & 630 & & 630 & & 630 & \\
\hline Gemiddeld cijfer eerste jaar & 2,165 & *** & 2,201 & $* * *$ & 2,052 & *** \\
\hline Model Chi2 & 172,462 & *** & 216,716 & $* * *$ & 229,479 & *** \\
\hline Df & 8 & & 26 & & 30 & \\
\hline $\mathrm{N}$ & 630 & & 630 & & 630 & \\
\hline Kritisch denken & 0,014 & $* * *$ & 0,010 & * & 0,017 & *** \\
\hline Creativiteit & $-0,006$ & & $-0,014$ & & $-0,003$ & \\
\hline Gemiddeld ciffer eerste jaar & 2,085 & *** & 2,128 & $* * *$ & 1,967 & *** \\
\hline Model Chi2 & 188,947 & *** & 223,592 & $* * *$ & 248,652 & *** \\
\hline Df & 12 & & 30 & & 34 & \\
\hline $\mathrm{N}$ & 630 & & 630 & & 630 & \\
\hline
\end{tabular}

$\sim p<0,1 ;{ }^{*} p<0,05 ;{ }^{* *} p<0,01 ;{ }^{* * *} p<0,001$ 
TABEL 9 Multinomiaal logistisch regressiemodel van de kans op deelname aan een excellentieprogramma, naar hbo en wo

\begin{tabular}{|c|c|c|c|c|c|c|}
\hline Deelname versus geen deelname, WEL in aanmerking gekomen & M1 & & M2 & & M3 & \\
\hline \multicolumn{7}{|l|}{ HBO } \\
\hline Kritisch denken & 0,023 & * & 0,025 & * & 0,023 & * \\
\hline Model Chi2 & 16,850 & ** & 37,661 & * & 70,094 & *** \\
\hline Df & 6 & & 24 & & 28 & \\
\hline N & 216 & & 216 & & 216 & \\
\hline Creativiteit & 0,071 & $\sim$ & 0,076 & $\sim$ & 0,106 & * \\
\hline Model Chi2 & 11,202 & $\sim$ & 32,652 & & 69,599 & *** \\
\hline Df & 6 & & 24 & & 28 & \\
\hline N & 216 & & 216 & & 216 & \\
\hline Gemiddeld cijfer eerste jaar & 1,027 & * & 1,180 & * & 1,190 & * \\
\hline Model Chi2 & 25,284 & $* * *$ & 49,010 & ** & 74,024 & $* * *$ \\
\hline Df & 6 & & 24 & & 28 & \\
\hline N & 216 & & 216 & & 216 & \\
\hline Kritisch denken & 0,021 & $\sim$ & 0,023 & * & 0,018 & \\
\hline Creativiteit & 0,044 & & 0,052 & & 0,087 & $\sim$ \\
\hline Gemiddeld cijfer eerste jaar & 1,116 & * & 1,234 & * & 1,231 & * \\
\hline Model Chi2 & 37,227 & *** & 59,128 & $* * *$ & 85,555 & $* * *$ \\
\hline Df & 10 & & 28 & & 32 & \\
\hline N & 216 & & 216 & & 216 & \\
\hline \multicolumn{7}{|l|}{ wo } \\
\hline Kritisch denken & 0,003 & & $-0,001$ & & 0,006 & \\
\hline Model Chi2 & 62,921 & $* * *$ & 104,197 & $* * *$ & 146,025 & $* * *$ \\
\hline Df & 8 & & 26 & & 30 & \\
\hline N & 630 & & 630 & & 630 & \\
\hline Creativiteit & 0,022 & & 0,010 & & 0,020 & \\
\hline Model Chi2 & 31,880 & $* * *$ & 81,976 & $* * *$ & 113,237 & $* * *$ \\
\hline Df & 8 & & 26 & & 30 & \\
\hline $\mathrm{N}$ & 630 & & 630 & & 630 & \\
\hline Gemiddeld cijfer eerste jaar & 0,142 & & 0,127 & & 0,095 & \\
\hline Model Chi2 & 172,462 & $* * *$ & 216,716 & $* * *$ & 229,479 & $* * *$ \\
\hline Df & 8 & & 26 & & 30 & \\
\hline N & 630 & & 630 & & 630 & \\
\hline Kritisch denken & 0,002 & & $-0,002$ & & 0,005 & \\
\hline Creativiteit & 0,017 & & 0,012 & & 0,017 & \\
\hline Gemiddeld cijfer eerste jaar & 0,111 & & 0,145 & & 0,036 & \\
\hline Model Chi2 & 188,947 & *** & 223,592 & $* * *$ & 248,652 & $* * *$ \\
\hline Df & 12 & & 30 & & 34 & \\
\hline N & 630 & & 630 & & 630 & \\
\hline
\end{tabular}

$\sim p<0,1 ;{ }^{*} p<0,05 ;{ }^{* *} p<0,01 ;{ }^{* * *} p<0,001$ 
TABEL 10 Logistisch regressiemodel van de kans op succesvolle afronding excellentieprogramma

\begin{tabular}{|c|c|c|c|c|c|c|c|c|}
\hline \multirow[b]{2}{*}{ Intercept } & \multicolumn{2}{|c|}{$M 1^{\mathrm{a}}$} & \multicolumn{2}{|c|}{$M 2^{\mathrm{a}}$} & \multicolumn{2}{|l|}{$M 3^{\mathrm{a}}$} & \multicolumn{2}{|c|}{$M 4^{a}$} \\
\hline & 0,770 & * & 0,489 & & $-2,082$ & & 2,052 & ** \\
\hline Kritisch denken & $-0,003$ & & $-0,006$ & & 0,001 & & $-0,001$ & \\
\hline \multicolumn{9}{|l|}{ Achtergrondkenmerken student } \\
\hline Ten minste één ouder van Nederlandse afkomst & & & $-0,129$ & & & & & \\
\hline Nederlandse taal & & & 0,340 & & & & & \\
\hline \multicolumn{9}{|l|}{ Hoogste opleiding ouders } \\
\hline Basisonderwijs (ref.=W0) & & & $-0,597$ & & & & & \\
\hline LBO, VMBO, MAVO (ref.=W0) & & & $-0,746$ & & & & & \\
\hline HAVO, VWO (ref.=W0) & & & 1,540 & $\sim$ & & & & \\
\hline MBO (ref.=W0) & & & $-0,002$ & & & & & \\
\hline HBO (ref.=WO) & & & 0,422 & & & & & \\
\hline \multicolumn{9}{|l|}{ Inkomen ouders } \\
\hline Beneden modaal (ref.= Modaal) & & & 0,587 & & & & & \\
\hline Boven modaal (ref.= Modaal) & & & 0,187 & & & & & \\
\hline \multicolumn{9}{|l|}{ Motivatiekenmerken student } \\
\hline Intrinsieke motivatie & & & & & 0,106 & & & \\
\hline Extrinsieke motivatie & & & & & $-0,055$ & & & \\
\hline Consistentie van inzet & & & & & 0,291 & & & \\
\hline Doorzettingsvermogen & & & & & 0,352 & & & \\
\hline \multicolumn{9}{|l|}{ Big five persoonlijkheidskenmerken student } \\
\hline Neuroticisme & & & & & 0,140 & & & \\
\hline Extraversie & & & & & $-0,014$ & & & \\
\hline Openheid & & & & & 0,015 & & & \\
\hline Inschikkelijkheid & & & & & 0,147 & & & \\
\hline Zorgvuldigheid & & & & & 0,258 & & & \\
\hline Zelfeffectiviteit & & & & & $-0,707$ & & & \\
\hline Risicopreferentie & & & & & 0,151 & $\sim$ & & \\
\hline \multicolumn{9}{|l|}{ Nevenactiviteiten student } \\
\hline Stage gevolgd in Nederland & & & & & & & $-0,513$ & \\
\hline Stage of onderwijs gevolgd in buitenland & & & & & & & 0,139 & \\
\hline Aantal uren in de week buiten de studie actief & & & & & & & $-0,019$ & \\
\hline Aantal uren in de week betaald werk & & & & & & & $-0,110$ & ** \\
\hline Model Chi2 & 50,829 & **** & 61,402 & *** & 62,504 & *** & 66,518 & *** \\
\hline Df & 6 & & 15 & & 17 & & 10 & \\
\hline N & 311 & & 311 & & 311 & & 311 & \\
\hline
\end{tabular}

$\sim \mathrm{p}<0,1 ;{ }^{*} \mathrm{p}<0,05 ;{ }^{* *} \mathrm{p}<0,01 ;{ }^{* * *} \mathrm{p}<0,001$

${ }^{a}$ gecontroleerd voor instelling en cohort 
TABEL 11 Logistisch regressiemodel van de kans op succesvolle afronding excellentieprogramma

\begin{tabular}{|c|c|c|c|c|c|c|c|c|}
\hline & \multicolumn{2}{|c|}{$M 1^{a}$} & \multicolumn{2}{|c|}{$M 2^{\mathrm{b}}$} & \multicolumn{2}{|c|}{ M3c } & \multicolumn{2}{|c|}{$M 4^{d}$} \\
\hline Kritisch denken & $-0,003$ & & $-0,006$ & & 0,001 & & $-0,001$ & \\
\hline Model Chi2 & 50,829 & $* * *$ & 61,402 & $* * *$ & 62,504 & $* * *$ & 66,518 & *** \\
\hline Df & 6 & & 15 & & 17 & & 10 & \\
\hline N & 311 & & 311 & & 311 & & 311 & \\
\hline Creativiteit & 0,025 & & 0,021 & & 0,033 & & 0,038 & \\
\hline Model Chi2 & 51,387 & $* * *$ & 60,834 & *** & 63,951 & $* * *$ & 68,177 & *** \\
\hline Df & 6 & & 15 & & 17 & & 10 & \\
\hline N & 311 & & 311 & & 311 & & 311 & \\
\hline Studieresultaten Gemiddeld cijfer eerste jaar & $-0,069$ & & $-0,172$ & & $-0,085$ & & $-0,092$ & \\
\hline Model Chi2 & 50,505 & $* * *$ & 60,474 & $* * *$ & 62,515 & $* * *$ & 66,493 & $* * *$ \\
\hline Df & 6 & & 15 & & 17 & & 10 & \\
\hline N & 311 & & 311 & & 311 & & 311 & \\
\hline Selecteursoordeel & 0,200 & & 0,261 & & 0,356 & & 0,388 & \\
\hline Model Chi2 & 41,030 & $* * *$ & 50,398 & $* * *$ & 53,760 & $* * *$ & 56,536 & *** \\
\hline Df & 6 & & 15 & & 17 & & 10 & \\
\hline N & 276 & & 276 & & 276 & & 276 & \\
\hline Kritisch denken & $-0,003$ & & $-0,005$ & & 0,001 & & $-0,002$ & \\
\hline Creativiteit & 0,019 & & 0,014 & & 0,020 & & 0,028 & \\
\hline Studieresultaten Gemiddeld cijfer eerste jaar & $-0,138$ & & $-0,274$ & & $-0,244$ & & $-0,173$ & \\
\hline Selecteursoordeel & 0,187 & & 0,275 & & 0,340 & & 0,365 & \\
\hline Model Chi2 & 41,713 & $* * *$ & 51,697 & *** & 54,677 & $* * *$ & 57,588 & *** \\
\hline Df & 9 & & 18 & & 20 & & 13 & \\
\hline N & 276 & & 276 & & 276 & & 276 & \\
\hline
\end{tabular}

$\sim p<0.1 * p<0.05,{ }^{* *} p<0.01,{ }^{* * *} p<0.001$

${ }^{a}$ gecontroleerd voor instelling en cohort

${ }^{\mathrm{b}}$ gecontroleerd voor instelling, cohort, achtergrondkenmerken student, hoogste opleiding ouders en inkomen ouders

' gecontroleerd voor instelling, cohort, motivatiekenmerken student en big five persoonlijkheidskenmerken student

${ }^{d}$ gecontroleerd voor instelling, cohort en nevenactiviteiten student 
TABEL 12 Logistisch regressiemodel van de kans op succesvolle afronding excellentieprogramma, naar hbo en wo

\begin{tabular}{|c|c|c|c|c|c|c|c|c|}
\hline \multirow[b]{2}{*}{ HBO } & \multicolumn{2}{|l|}{$M 1^{\mathrm{a}}$} & \multicolumn{2}{|c|}{$M 2^{b}$} & \multicolumn{2}{|l|}{$\mathrm{M}^{\mathrm{c}}$} & \multicolumn{2}{|l|}{$M 4^{d}$} \\
\hline & & & & & & & & \\
\hline Kritisch denken & $-0,023$ & * & $-0,034$ & ** & $-0,020$ & $\sim$ & $-0,024$ & * \\
\hline Model Chi2 & 14,010 & ** & 31,435 & *** & 22,747 & $\sim$ & 18,837 & ** \\
\hline Df & 3 & & 12 & & 14 & & 7 & \\
\hline $\mathrm{N}$ & 100 & & 100 & & 100 & & 100 & \\
\hline Creativiteit & $-0,022$ & & $-0,040$ & & $-0,036$ & & $-0,021$ & \\
\hline Model Chi2 & 9,277 & * & 23,647 & * & 20,113 & & 14,005 & $\sim$ \\
\hline Df & 3 & & 12 & & 14 & & 7 & \\
\hline $\mathrm{N}$ & 100 & & 100 & & 100 & & 100 & \\
\hline Studieresultaten Gemiddeld ciffer eerste jaar & $-0,370$ & & $-0,166$ & & $-0,936$ & & $-0,434$ & \\
\hline Model Chi2 & 9,286 & * & 23,013 & * & 20,972 & & 14,187 & * \\
\hline Df & 3 & & 12 & & 14 & & 7 & \\
\hline $\mathrm{N}$ & 100 & & 100 & & 100 & & 100 & \\
\hline Selecteursoordeel & 0,391 & & 0,448 & & 0,676 & & 0,619 & \\
\hline Model Chi2 & 6,313 & $\sim$ & 20,853 & $\sim$ & 17,795 & & 12,610 & $\sim$ \\
\hline Df & 3 & & 12 & & 14 & & 7 & \\
\hline N & 96 & & 96 & & 96 & & 96 & \\
\hline Kritisch denken & $-0,024$ & * & $-0,035$ & ** & $-0,020$ & & $-0,025$ & * \\
\hline Creativiteit & 0,012 & & $-0,008$ & & $-0,001$ & & 0,009 & \\
\hline Studieresultaten Gemiddeld cijfer eerste jaar & $-0,299$ & & 0,046 & & $-0,876$ & & $-0,347$ & \\
\hline Selecteursoordeel & 0,343 & & 0,567 & & 0,671 & & 0,582 & \\
\hline Model Chi2 & 11,795 & $\sim$ & 29,502 & * & 22,365 & & 18,022 & $\sim$ \\
\hline Df & 6 & & 15 & & 17 & & 10 & \\
\hline $\mathrm{N}$ & 96 & & 96 & & 96 & & 96 & \\
\hline wo & & & & & & & & \\
\hline Kritisch denken & 0,003 & & 0,004 & & 0,008 & & 0,007 & \\
\hline Model Chi2 & 19,894 & *** & 27,968 & ** & 33,157 & ** & 29,104 & *** \\
\hline Df & 4 & & 13 & & 15 & & 8 & \\
\hline $\mathrm{N}$ & 211 & & 211 & & 211 & & 211 & \\
\hline Creativiteit & 0,068 & $\sim$ & 0,070 & $\sim$ & 0,085 & * & 0,085 & * \\
\hline Model Chi2 & 23,084 & **** & 30,659 & * & 36,269 & ** & 32,788 & *** \\
\hline Df & 4 & & 13 & & 15 & & 8 & \\
\hline N & 211 & & 211 & & 211 & & 211 & \\
\hline Studieresultaten Gemiddeld cijfer eerste jaar & 0,014 & & $-0,149$ & & 0,039 & & 0,064 & \\
\hline Model Chi2 & 19,534 & *** & 27,750 & ** & 31,524 & ** & 27,903 & *** \\
\hline Df & 4 & & 13 & & 15 & & 8 & \\
\hline $\mathrm{N}$ & 211 & & 211 & & 211 & & 211 & \\
\hline Selecteursoordeel & 0,028 & & $-0,180$ & & 0,217 & & 0,203 & \\
\hline Model Chi2 & 13,453 & ** & 23,701 & * & 23,872 & $\sim$ & 19,468 & * \\
\hline
\end{tabular}




\begin{tabular}{|l|r|r|r|r|r|}
\hline Df & 4 & 13 & 15 & 8 \\
\hline N & 180 & 180 & 180 & 180 \\
\hline Kritisch denken & 0,005 & 0,008 & 0,008 & 0,006 \\
\hline Creativiteit & 0,045 & 0,043 & 0,051 & 0,054 \\
\hline Studieresultaten Gemiddeld cijfer eerste jaar & $-0,130$ & $-0,383$ & $-0,203$ & $-0,158$ \\
\hline Selecteursoordeel & $-0,144$ & $-0,350$ & 0,053 & 0,022 \\
\hline Model Chi2 & $16,023 *$ & 26,448 & $*$ & 27,791 & $\sim$ \\
\hline Df & 7 & 16 & 18 & $23,057{ }^{*}$ \\
\hline N & 180 & 180 & 180 & 11 \\
\hline$\sim \mathrm{p}<0.1 *$ & & 180 \\
\hline
\end{tabular}

${ }^{a}$ gecontroleerd voor instelling en cohort

${ }^{\mathrm{b}}$ gecontroleerd voor instelling, cohort, achtergrondkenmerken student, hoogste opleiding ouders en inkomen ouders

' gecontroleerd voor instelling, cohort, motivatiekenmerken student en big five persoonlijkheidskenmerken student

${ }^{\mathrm{d}}$ gecontroleerd voor instelling, cohort en nevenactiviteiten student

\subsection{Voorkeuren van selecteurs van excellentieprogramma's}

\subsubsection{Inleiding}

In deze paragraaf wordt aan de hand van een vignettenonderzoek gekeken naar de preferenties van selecteurs bij de selectie van studenten voor deelname aan excellentieprogramma's. De analyses geven antwoord op de onderzoeksvraag welke kenmerken selecteurs van excellentieprogramma's het belangrijkst vinden en welke kenmerken significant de kans beïnvloeden om aangenomen te worden voor een excellentieprogramma. De hoofdanalyses voor het vignettenonderzoek bestaan uit logistische regressiemodellen die de kans schatten dat een student wordt aangenomen bij een excellentieprogramma op basis van de hierboven genoemde kenmerken. Voordat deze modellen worden besproken, zullen eerst beschrijvende statistieken beschreven worden om zo het profiel van de deelnemende selecteurs beter in beeld te krijgen.

\subsubsection{Beschrijvende statistieken}

Als eerste worden in dit gedeelte de achtergronden van de selecteurs beschreven die deel genomen hebben aan dit vignettenonderzoek. Vervolgens bespreken we de verschillende excellentieprogramma's waarvoor deze selecteurs werkzaam zijn.

Zoals in hoofdstuk 2 al in meer detail beschreven werd, zijn voor het vignettenonderzoek selecteurs van excellentieprogramma's gevraagd om fictieve studenten aan te nemen voor hun excellentieprogramma. Deze selecteurs zijn afkomstig van 18 verschillende instellingen in Nederland.

De selecteurs zijn van zowel instellingen in het hoger beroepsonderwijs (hbo) als in het wetenschappelijk onderwijs (wo). lets minder dan de helft van de selecteurs is gelieerd aan een instelling in het wetenschappelijk onderwijs (44\%) en $56 \%$ van de selecteurs is betrokken bij excellentieprogramma's in het hoger beroepsonderwijs (zie Figuur 1). 
FIGUUR 1 Percentage selecteurs naar hbo en wo instellingen

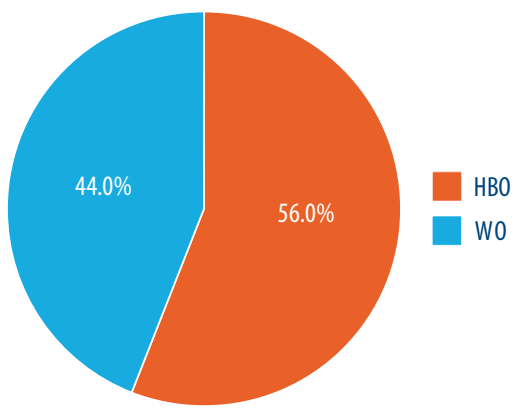

FIGUUR 2 Het aantal excellentieprogramma's waarbij de selecteur betrokken is

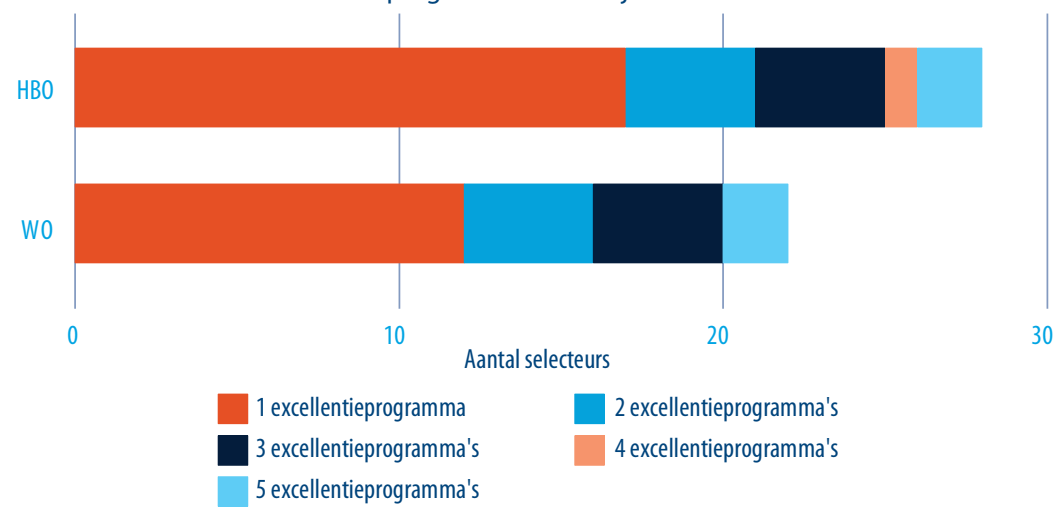

lets minder dan de helft van deze selecteurs is betrokken bij meerdere excellentieprogramma's (zie ook Figuur 2). Het overgrote deel van de selecteurs is echter betrokken bij maar één excellentieprogramma, in het hbo 17 selecteurs en in het wo 12 selecteurs. Vervolgens zijn in het hbo 4 selecteurs betrokken bij twee excellentieprogramma's, 4 selecteurs betrokken bij drie excellentieprogramma's, 1 selecteur betrokken bij vier programma's en 2 selecteurs betrokken bij vijf of meer excellentieprogramma's. In het wo zijn 4 selecteurs betrokken bij twee excellentieprogramma's, en 4 betrokken bij drie programma's, en 2 selecteurs betrokken bij vijf of meer excellentieprogramma's.

Aan de hand van de volgende figuren bespreken we de achtergrondkenmerken van de excellentieprogramma's waarvoor de selecteurs werkzaam zijn. Daarbij is het eerste kenmerk van het excellentieprogramma het tijdsframe waarbinnen de student het excellentieprogramma volgt (Figuur 3). 
FIGUUR 3 In welk jaar start het excellentieprogramma

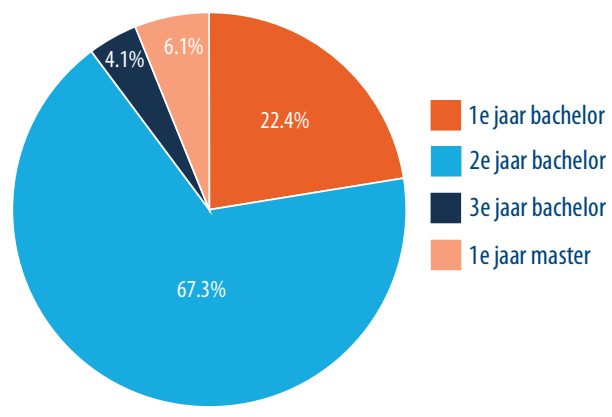

Sommige excellentieprogramma's starten in de bachelor, en verschillen in welk jaar van de bachelor het programma begint. Andere excellentieprogramma's starten in de masterfase van de student. De meeste excellentieprogramma's, $67 \%$, beginnen in het tweede jaar van de bacheloropleiding.

FIGUUR 4 Het sollicitatieproces van het excellentieprogramma

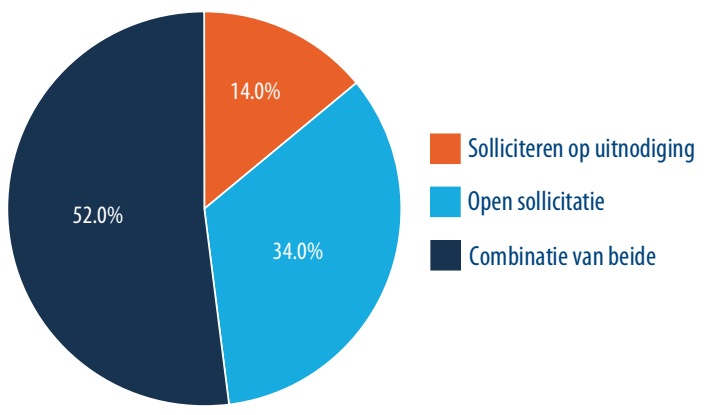

Het sollicitatieproces om deel te nemen aan excellentieprogramma's is ook een belangrijk kenmerk van excellentieprogramma's (Figuur 4). Zo kunnen studenten geselecteerd worden door bijvoorbeeld docenten of betrokkenen bij het excellentieprogramma en is de sollicitatie puur op uitnodiging (14\%), daarnaast is open sollicitatie voor excellentieprogramma's bij 34\% van de opleidingen gebruikelijk. Echter het overgrote gedeelte, $52 \%$ van de excellentieprogramma's, gebruikt een combinatie van zowel open solliciteren als solliciteren op uitnodiging. 
FIGUUR 5 Cijfer-restrictie eis voor selectie van studenten tot excellentieprogramma

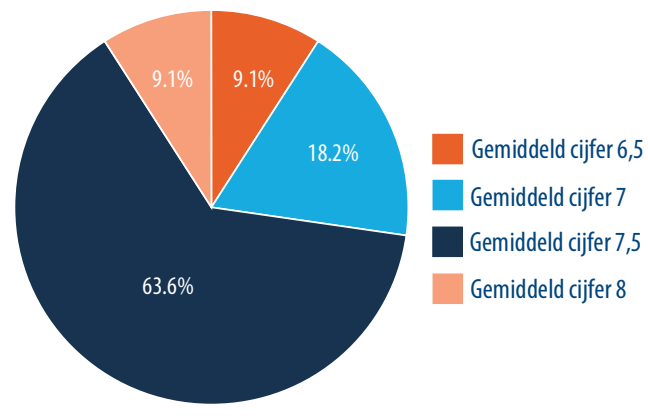

Om in aanmerking te komen voor een excellentieprogramma's zijn er vaak programma's die gebruik maken van harde eisen voor de toelating van studenten (zie Figuur 5). 46\% van de selecteurs in dit onderzoek geeft aan dat er eisen zijn voor de toelating van de studenten. Eisen kunnen bijvoorbeeld zijn het nominaal halen van het eerste studiejaar/ bachelor etc. De meest voorkomende eis is een cijfer-eis. Studenten dienen minimaal een bepaald cijfer te hebben gehaald in de jaren voor de start van het excellentieprogramma. Van de $46 \%$ van de selecteurs die aangeeft dat er eisen zijn voor de toelating, wordt in Figuur 5 de cijfer-eis weergegeven: $54 \%$ van de excellentieprogramma's heeft zo'n harde cijfer-eis, $46 \%$ van de excellentieprogramma's niet. Als er een harde cijfer-eis is voor de studenten om deel te nemen aan excellentieprogramma's zien we dat het cijfer dat de student moet hebben gehaald ook nog kan verschillen. Bij $9 \%$ van de excellentieprogramma's dient de student gemiddeld ten minste een 6,5 te staan, bij $18 \%$ dient de student ten minste een 7 gehaald te hebben. Het overgrote deel, bijna $64 \%$ van de excellentieprogramma's, houdt en 7,5 aan als cijferrestrictie. De strengste excellentieprogramma's, zo'n 9\%, houden een 8 aan als cijfer eis.

FIGUUR 6 Hebben excellentieprogramma's al eens studenten aangenomen die niet aan de sollicitatie-eisen voldeden?

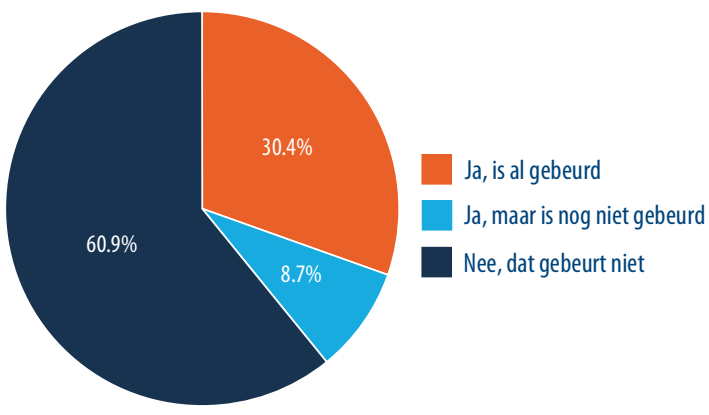

Als excellentieprogramma's bepaalde eisen hebben voor de selectie van studenten kan het soms zo zijn dat er wordt afgeweken van de harde eis om toch een student aan 
te nemen (zie Figuur 6). De flexibiliteit om af te wijken hiervan verschilt. Bij zo'n 61\% van de excellentieprogramma's is er geen flexibiliteit en kan een student niet worden aangenomen als deze niet voldoet aan de eisen. Daarnaast is er bij zo'n $30 \%$ van de instellingen wel flexibiliteit in de harde eis en is hier ook al gebruik van gemaakt, terwijl bij $9 \%$ van de instellingen wel de flexibiliteit bestaat, maar het nog niet is voorgekomen dat er van de eis is afgeweken.

FIGUUR 7 Het aantal toe te wijzen plekken binnen het excellentieprogramma waarbij selecteurs betrokken zijn

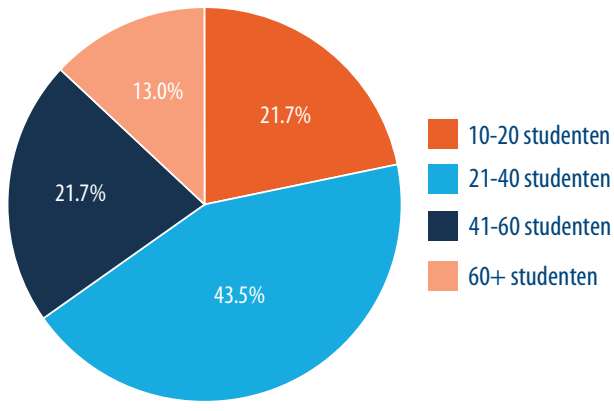

De omvang van de excellentieprogramma's waarbij de selecteurs betrokken zijn verschilt. De kleinste excellentieprogramma's hebben tussen de 10-20 studenten, en dit is het geval bij ongeveer $22 \%$ van de selecteurs. Daarnaast heeft $44 \%$ van de excellentieprogramma's een aantal studenten tussen de 21 en $40.22 \%$ van de excellentieprogramma's heeft tussen de 41 en 60 studenten per jaar, en 13\% van de excellentieprogramma's trekt meer dan 60 studenten per academisch jaar aan.

\subsubsection{Kenmerken voor het aannemen van studenten}

Vervolgens is aan de selecteurs een aantal kenmerken van studenten voorgelegd en gevraagd a) welke kenmerken volgens hen niet aanvaardbaar zijn voor studenten die mogen deelnemen aan een excellentieprogramma en b) omgekeerd, welke kenmerken ze juist belangrijk vinden in studenten die deelnemen aan excellentieprogramma's. De keuze van de kenmerken die zijn voorgelegd is gebaseerd op een pilot waarbij in de interviews met selecteurs (zie paragraaf 2.4) een aantal kenmerken is voorgelegd en besproken. Op basis van de resultaten van deze bespreking en de praktische beperking in het aantal kenmerken dat in een dergelijke opzet opgenomen kan worden, is een selectie gemaakt van kenmerken die in het uiteindelijke onderzoek zijn voorgelegd. Allereerst laten Figuren 8 en 9 voor verschillende kenmerken het percentage selecteurs zien, dat deze kenmerken als'niet aanvaardbaar' ziet. We zien dat voor alle kenmerken studenten die behoren tot de laagste $25 \%$ worden gezien als 'niet aanvaardbaar' voor ongeveer $40 \%-75 \%$ van de selecteurs (bijvoorbeeld, Figuur 8 laat zien dat $72 \%$ van de selecteurs het niet aanvaardbaar vindt als studenten in hun denkvermogen tot de laagste $25 \%$ behoren). Wanneer wordt gekeken naar de kenmerken waarbij de fictieve student zou behoren tot de top $25 \%$ zien 
we uiteraard dat nauwelijks selecteurs dit zien als 'niet aanvaardbaar'. Meer verrassend is wellicht dat ook een gemiddelde score op de kenmerken door selecteurs nauwelijks als 'niet aanvaardbaar' bestempeld wordt; blijkbaar ligt voor selecteurs de grens tussen aanvaardbaar en niet aanvaardbaar niet zozeer tussen de meest excellente studenten en de rest, maar tussen de gemiddelde student en de zwakste groep.

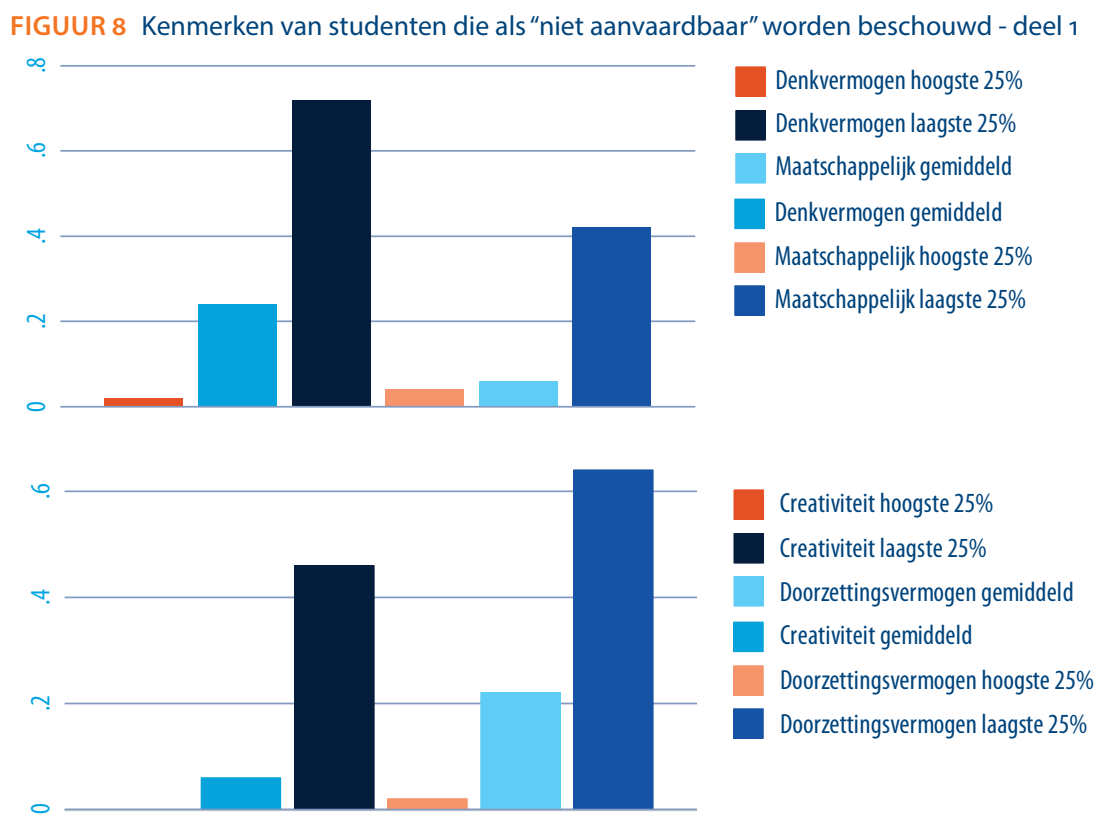

De belangrijkste kenmerken die worden gezien als 'niet-aanvaardbaar' zijn een lage motivatie (maar liefst $76 \%$ van de selecteurs vindt dit niet aanvaardbaar), een laag denkvermogen ( $72 \%$ vindt dit niet aanvaardbaar), en een laag doorzettingsvermogen (64\%). Alleen bij deze drie kenmerken zien we dat een gemiddeld scorende student ook al in enkele gevallen als niet-aanvaardbaar wordt gezien voor een excellentieprogramma ( $36 \%$ voor motivatie, $24 \%$ voor denkvermogen en $22 \%$ voor doorzettingsvermogen).

De selecteurs konden ook aangeven in welke volgorde ze de besproken kenmerken wél belangrijk vonden bij de selectie van studenten voor excellentieprogramma's. Daarbij zijn de kenmerken waarbij ze aangaven dat deze 'niet aanvaardbaar' waren al uitgefilterd. In Figuur 10 wordt weergegeven welke kenmerken het vaakst in de top 5 van de selecteurs stonden.

Deze figuur laat zien hoevaak een kenmerk wordt gekozen binnen de top 5 van een selecteur. Het vaakst wordt gekozen voor een student die behoort tot de top $25 \%$ als het aankomt op motivatie, dit kenmerk wordt door 32 van de 50 selecteurs in de top 5 gezet. Op de tweede plek staan studenten behorende tot de top $25 \%$ denkvermogen, gekozen 
door 29/50 selecteurs in de top 5 . Studenten die als beste $25 \%$ behoren op doorzettingsvermogen staan op de derde plaats.

FIGUUR 9 Kenmerken van studenten die als "niet aanvaardbaar" worden beschouwd - deel 2

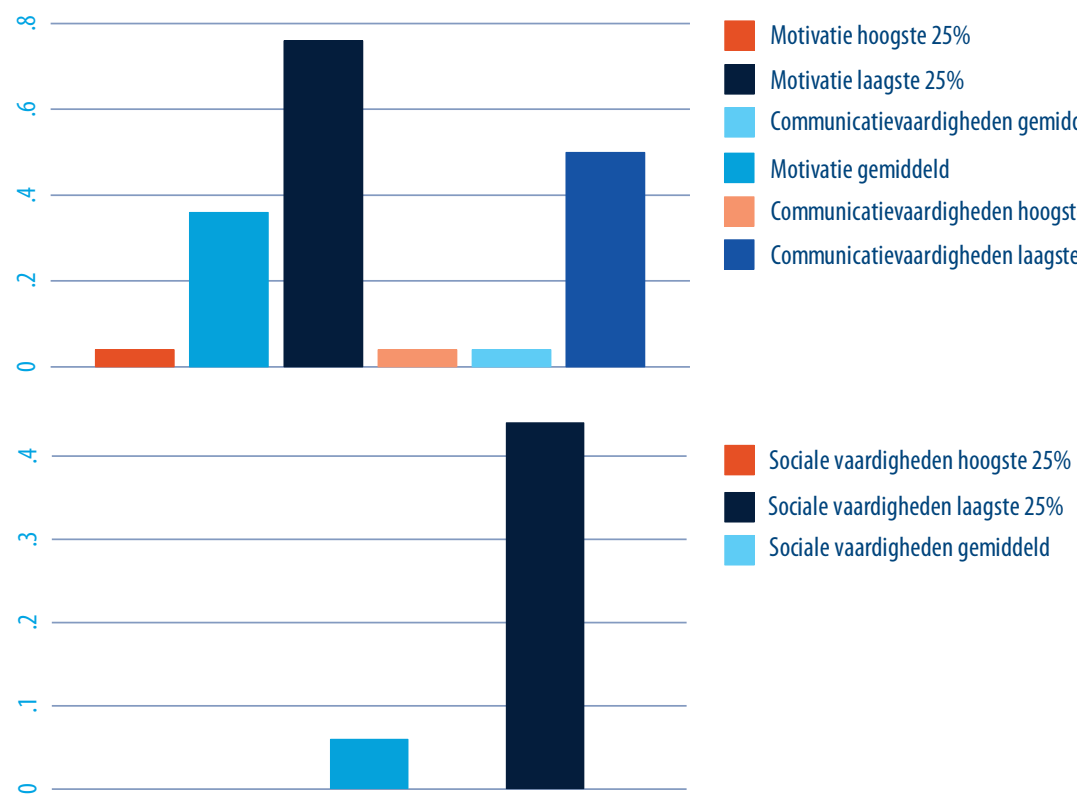

FIGUUR 10 Belangrijkste kenmerken voor het aannemen van studenten voor excellentieprogramma's

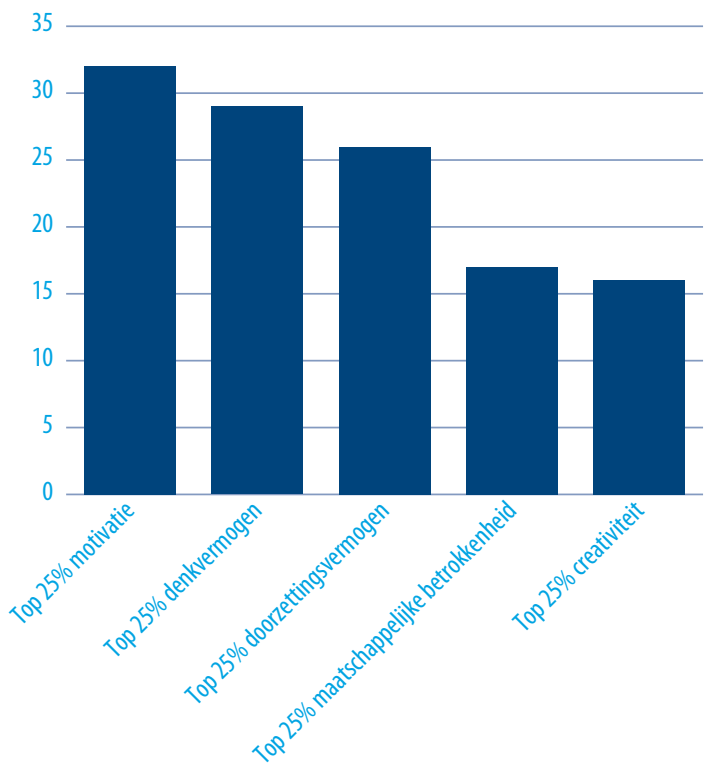




\subsubsection{Wat bepaalt de kans om te worden aangenomen voor een excellentieprogramma?}

Tot slot bekijken we de resultaten van de vignettenanalyse, waarin selecteurs moesten aangeven welke studenten zij in een hypothetisch geval zouden aannemen (zie hoofdstuk 2 voor een beschrijving van de precieze opzet van de vignetten). Hieruit kunnen we afleiden welke kenmerken de kans om te worden geselecteerd voor een excellentieprogramma vergroten dan wel verkleinen. Dit doen we middels logistische regressieanalyses, waarin we de kans om geselecteerd te worden herleiden tot het hebben van een bijbaan, buitenlandervaring, het gemiddelde cijfer, en het doen van vrijwilligerswerk. In Tabel 13 worden de logistische regressie-modellen getoond met de kans voor een student om aangenomen te worden voor een excellentieprogramma. In de tabellen staan kansverhoudingen: de kans dat de student wordt aangenomen versus dat de student niet wordt aangenomen.

TABEL 13 Logistische regressie vignettenstudie

\begin{tabular}{l|l|}
\hline $\begin{array}{l}\text { Bijbaan (ref.= geen bijbaan) } \\
\text { Studiegerelateerde bijbaan }\end{array}$ & Model 1 \\
\hline $\begin{array}{l}\text { Niet-studiegerelateerde bijbaan } \\
\text { Buitenlandervaring (ref.=geen ervaring) }\end{array}$ & $2.137^{* * *}$ \\
\hline Jaar reizen in het buitenland & 1.103 \\
\hline Studie/stage in het buitenland & $2.565^{* * *}$ \\
\hline \begin{tabular}{l} 
Gemiddeld cijfer (ref.=gemiddeld) \\
\hline Gemiddelde cijfer onder het gemiddelde
\end{tabular} & $3.455^{* * *}$ \\
\hline Gemiddelde cijfer boven het gemiddelde & $0.284^{* * *}$ \\
\hline Gemiddelde cijfer bij de beste 10\% & $2.871^{* * *}$ \\
\hline Vrijwilligerswerk (ref.=geen werk) & $4.947^{* * *}$ \\
\hline Student doet wel aan vrijwilligerswerk & $3.223^{* * *}$ \\
\hline Constant & $0.041^{* * *}$ \\
\hline N & 2250 \\
\hline * p<o.05, \\
Noot: odds ratio's zijn weergegeven
\end{tabular}

De resultaten kunnen als volgt worden geïnterpreteerd. Met betrekking tot het hebben van een bijbaan, hebben studenten met een studiegerelateerde bijbaan 2,1 keer meer kans om gekozen te worden vergeleken met studenten die geen bijbaan hebben. Studenten die een niet-studiegerelateerde bijbaan hebben gehad, hebben niet significant meer kans om gekozen te worden voor een excellentieprogramma vergeleken met studenten zonder een bijbaan.

Studenten die buitenlandervaring hebben (zowel een jaar reizen als het volgen van een stage/studie) hebben significant meer kans dan studenten die geen buitenlandervaring hebben. Studenten die een jaar hebben gereisd hebben 2,6 keer meer kans om aangenomen te worden, en studenten die een studie/stage in het buitenland hebben gevolgd hebben zelfs 3,5 keer meer kans om aangenomen te worden dan studenten die geen buitenlandervaring hebben. 
Het gemiddeld cijfer van een student heeft ook significant invloed op de kans om aangenomen te worden voor een excellentieprogramma. De referentiewaarde waarmee vergeleken wordt, zijn studenten die een 'gemiddeld' cijfer hebben in het afgelopen jaar. Studenten die onder dit gemiddelde cijfer scoren hebben significant minder kans om aangenomen te worden, ze hebben namelijk $70 \%$ minder kans om aangenomen te worden vergeleken met studenten die gemiddelde cijfers halen. Daarentegen hebben studenten die hogere cijfers halen significant meer kans om aangenomen te worden. Studenten met boven gemiddelde cijfers, hebben 2,9 keer meer kans om aangenomen te worden vergeleken met studenten die gemiddeld scoren, en studenten die behoren tot de top $10 \%$ van de klas hebben zelfs bijna 5 keer meer kans om aangenomen te worden vergeleken met gemiddeld scorende studenten.

Ook het doen van vrijwilligerswerk vergroot significant de kans om aangenomen te worden voor een excellentieprogramma. De kans is namelijk 3,2 keer zo groot om aangenomen te worden voor studenten die wél vrijwilligerswerk doen.

In Tabel 14 zijn de resultaten weergegeven, uitgesplitst naar selecteurs werkzaam in het hbo (model 2) en het wo (model 3). In deze modellen valt op dat een jaar reizen in het buitenland belangrijker is voor selecteurs in het hbo dan in het wo (een kansverhouding van 3,1 versus een kansverhouding van 1,9). Daarentegen is het behaalde gemiddelde cijfer van minder belang in het hbo dan in het wo. Behoren tot de top 10\% van de klas geeft de student op het hbo maar 2,5 keer meer kans, tegenover maar liefst 14 keer meer in het wo. In het wo ligt de nadruk dus erg sterk op de behaalde cijfers van de student in het afgelopen jaar.

TABEL 14 Logistische regressie vignettenstudie - uitgesplitst naar niveau hbo of wo

\begin{tabular}{|c|c|c|c|}
\hline & $\begin{array}{c}\text { M1 } \\
\text { basis model }\end{array}$ & $\begin{array}{c}\text { M2 } \\
\text { hbo model }\end{array}$ & $\begin{array}{c}\mathrm{M} 3 \\
\text { wo model }\end{array}$ \\
\hline \multicolumn{4}{|l|}{ Bijbaan (ref.=Geen bijbaan) } \\
\hline Studiegerelateerde bijbaan & $2.137^{* * *}$ & $2.124^{* * *}$ & $2.292^{* * *}$ \\
\hline Niet-studiegerelateerde bijbaan & 1.103 & 1.071 & 1.302 \\
\hline \multicolumn{4}{|l|}{ Buitenlandervaring (ref.=Geen ervaring) } \\
\hline Jaar reizen in het buitenland & $2.565^{* * *}$ & $3.133^{* * *}$ & $1.948^{* *}$ \\
\hline Studie/stage in het buitenland & $3.455^{* * *}$ & $3.498^{* * *}$ & $3.455^{* * *}$ \\
\hline \multicolumn{4}{|l|}{ Gemiddelde cijfer (ref.=Gemiddeld cijfer) } \\
\hline Gemiddelde cijfer onder het gemiddelde & $0.284^{* * *}$ & $0.297^{* * *}$ & $0.133^{* * *}$ \\
\hline Gemiddelde cijfer boven het gemiddelde & $2.871^{* * *}$ & $1.825^{* *}$ & $6.077^{* * *}$ \\
\hline Gemiddelde cijfer bij de beste $10 \%$ & $4.947^{* * *}$ & $2.460^{* * *}$ & $14.076^{* * *}$ \\
\hline \multicolumn{4}{|l|}{ Vrijwilligerswerk (ref.=Geen vrijwilligerswerk) } \\
\hline Student doet wel aan vrijwilligerswerk & $3.224^{* * *}$ & $3.217^{* * *}$ & $3.434^{* * *}$ \\
\hline Constant & $0.041^{* * *}$ & $0.060^{* * *}$ & $0.019^{* * *}$ \\
\hline $\mathrm{N}$ & 2250 & 1260 & 990 \\
\hline
\end{tabular}




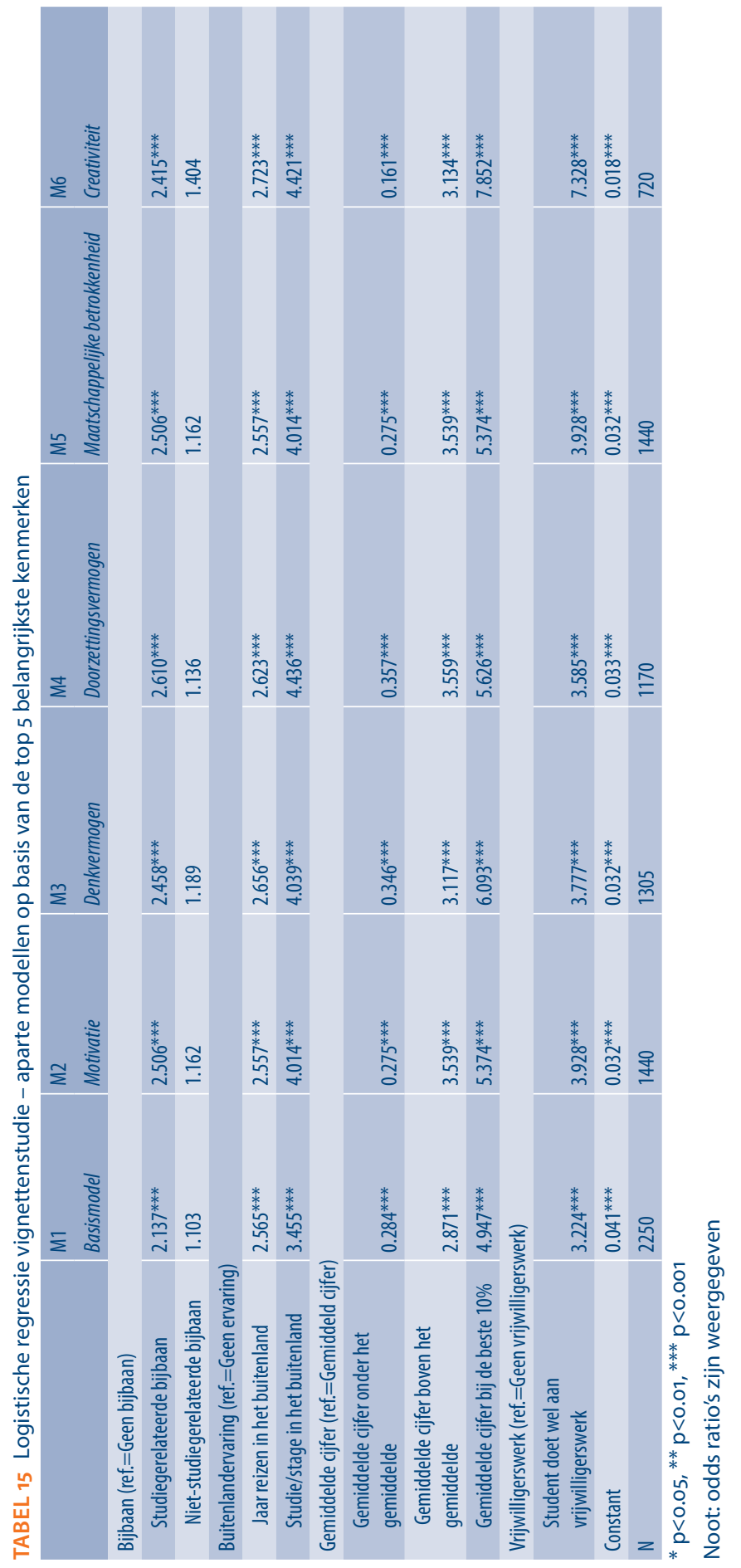


Tabel 15 laat de vignettenanalyse nogmaals zien, maar nu uitgesplitst voor selecteurs die aangeven een van de volgende vijf kenmerken als belangrijkste kenmerk te vinden voor het aannemen van studenten voor excellentieprogramma's: top $25 \%$ motivatie, top $25 \%$ denkvermogen, top $25 \%$ doorzettingsvermogen, top $25 \%$ maatschappelijke betrokkenheid en top $25 \%$ creativiteit. Met deze analyse kunnen we het verband laten zien tussen kenmerken die de selecteurs als belangrijk hebben genoemd en de uitkomsten van de vignetten. Als we dergelijke verbanden vinden laat dit immers zien dat selecteurs kenmerken die ze zelf als belangrijk bestempelen ook daadwerkelijk gebruiken in de keuzes die ze maken bij het selecteren van de studenten. Model 1 laat nogmaals het basismodel zien, waarmee de andere modellen kunnen worden vergeleken. Opmerkelijke resultaten zien we bijvoorbeeld in Model 3, waar gekeken wordt naar selecteurs die denkvermogen erg belangrijk vinden. In dit model hebben studenten met een gemiddeld cijfer behorende bij de beste $10 \%$ een veel grotere kans om aangenomen te worden vergeleken met het basismodel, namelijk 6,1 keer grotere kans versus 4,9 keer grotere kans. Ook is te zien in Model 6 dat selecteurs die creativiteit belangrijk vinden meer waarde hechten aan vrijwilligerswerk. In het basismodel hadden studenten die aan vrijwilligerswerk deden 3,2 keer meer kans om aangenomen te worden, in Model 6 hebben deze studenten maar liefst 7,3 keer zoveel kans. Ook is het opmerkelijk dat bij selecteurs die maatschappelijke betrokkenheid belangrijk vinden (Model 5), dit effect van vrijwilligerswerk een stuk kleiner is vergeleken met Model 6 . Al met al suggereert dit dat selecteurs het belang dat ze hechten aan bepaalde kenmerken ook daadwerkelijk vertalen naar de keuzes die ze maken bij de selectie van de studenten voor excellentieprogramma's. 



\section{EFFECTIVITEIT VAN EXCELLENTIEPROGRAMMA'S}

\subsection{Inleiding}

Dit hoofdstuk bespreekt de effecten van het volgen van excellentieprogramma's op meerdere cognitieve en non-cognitieve uitkomstmaten. Hiermee kan worden beantwoord wat de individuele toegevoegde waarde voor studenten is van het volgen van excellentieprogramma's. Naast studieresultaten worden andere cognitieve uitkomstmaten zoals kritisch denken en creativiteit onderzocht, en wordt er ook gekeken naar non-cognitieve vaardigheden zoals leiderschap en politieke betrokkenheid.

\section{Analysemethode}

Het multilevel repeated measures-model is een model waarbij de nulmeting en de eindmeting worden genest binnen een persoon, aangezien deze twee metingen tot deze persoon behoren. Het voordeel hiervan is dat de data zo getransformeerd kan worden, dat alle studenten die de nulmeting hebben ingevuld, meegenomen kunnen worden in het model, ongeacht of ze wel of niet een eindmeting hebben ingevuld. Dit vergroot de sample aanzienlijk, wat als voordeel heeft dat bepaalde relaties zichtbaarder worden door het grotere aantal studenten in de analyse. Dit model kan gezien worden als een groeimodel over de tijd $t$. Hierdoor kan worden geconstateerd of er een groei heeft plaatsgevonden in belangrijke cognitieve en non-cognitieve vaardigheden. Een belangrijke variabele in dit model is de variabele die de begin- en eindmeting aangeeft. Aan de hand van deze variabele kunnen interactiemodellen worden geschat, bijvoorbeeld met een interactievariabele tijd*regulier/honours, die aangeeft of over de tijd $t$ een groei heeft plaatsgevonden voor reguliere dan wel honoursstudenten en of deze groei significant verschilt tussen reguliere studenten en honoursstudenten met betrekking tot de gekozen uitkomstmaat. Uit dit model kan duidelijk worden gemaakt of de student gegroeid is op de desbetreffende uitkomstmaat tussen de begin- en eindmeting, en of dit verklaard kan worden door het volgen van een excellentieprogramma. Verder is het mogelijk om achtergrondkenmerken van de student toe te voegen om bij het vaststellen van de groei van de studenten te controleren voor kenmerken met betrekking tot de student, zijn/haar ouders en persoonlijkheids- en motivatiekenmerken. Daarnaast wordt er ook dummyvariabelen voor alle instellingen meegenomen in het model, omdat er verwacht wordt dat studenten binnen dezelfde instelling meer op elkaar lijken dan studenten van andere instellingen. Tot slot is ook een cohortindicator opgenomen, om eventuele verschillen tussen de twee cohorten van studenten te ondervangen. 
Ondanks gebruik van de beschreven analysemethode, is de sample nog steeds vrij klein, en zijn sommige relaties nauwelijks zichtbaar hierdoor. Daarom is ervoor gekozen om de significantie van de resultaten niet alleen te rapporteren met $p$-waarden van 0.01 en 0.05 , maar ook met een p-waarde van 0.10 , om zo ook in beeld te krijgen welke resultaten (marginaal) significant zijn bij een significantieniveau van $90 \%$.

\section{Modellenopbouw}

Voor alle uitkomstmaten zijn dezelfde multilevel repeated measures modellen geschat waarbij in het eerste model het effect van deelname aan excellentieprogramma's wordt meegenomen en het verschil tussen de nul- en eindmeting. In het tweede model wordt het interactie-effect van deelname aan excellentieprogramma's * het effect van de eindmeting toegevoegd. Dit interactie-effect is de groei-indicator die aangeeft of reguliere studenten dan wel honoursstudenten een andere groei doormaken tussen de nul en eindmeting. In het derde model wordt een indicator voor het studentencohort toegevoegd, aangezien de vragenlijst onder twee cohorten is afgenomen, en wordt een controle voor verschillen tussen de instellingen meegenomen volgens een instelling fixed effects ${ }^{5}$. Het vierde model voegt achtergrondkenmerken van de student toe aan alle kenmerken die in model 3 worden opgenomen en het vijfde model voegt persoonlijkheidskenmerken van de student toe aan alle kenmerken die in model 3 worden opgenomen. Voor elk model gebruiken we informatie over zoveel mogelijk respondenten. Dit betekent wel dat we niet in alle modellen precies dezelfde sample analyseren; naarmate we meer variabelen aan de modellen toevoegen wordt het aantal respondenten met geldige informatie op alle variabelen in het model namelijk kleiner. In sectie 4.7 rapporteren we daarom onder andere de resultaten van een extra analyse waarin we alle modellen nog eens geschat hebben voor de groep respondenten die wel voor alle variabelen in onze analyse geldige informatie hebben.

\section{Opbouw van dit hoofdstuk}

Per uitkomstmaat worden de resultaten van deze modellen weergegeven in tabellen. Daarnaast zullen er per uitkomstmaat ook enkele figuren worden getoond, zoals figuren waarbij de scores op de uitkomstmaten worden getoond voor zowel honoursstudenten en reguliere studenten, en een marginsplot waar de groei van beide groepen studenten wordt geschat naar aanleiding van het repeated measures multilevel-model waarbij meerdere controlevariabelen worden meegenomen. De volgende secties bespreken alle uitkomstmaten en de effecten van honoursprogramma's op deze uitkomstmaten. De analyses in secties $4.2 \mathrm{t} / \mathrm{m} 4.5$ betreffen alle studenten die hebben deelgenomen aan de vragenlijst. De analyses in sectie 4.6 betreffen alleen de studenten van de Universiteit van Maastricht waarvan studentadministratie data van verkregen is. De laatste sectie, sectie 4.7, bespreekt extra analyses om de resultaten in dit hoofdstuk verder uit te werken en te controleren, en om te bekijken of de hoofdresultaten veranderen aan de hand van andere analyses.

5

UCM studenten worden in deze analyses niet meegenomen omdat dit honoursstudenten zijn waarvoor geen controlegroep beschikbaar is. Daarnaast zat er voor deze groep studenten een langere tijd tussen de nulmeting en eindmeting in verband met de vormgeving van hun opleiding. 


\subsection{Kritisch denken}

In dit onderzoek wordt kritisch denken op drie verschillende manieren gemeten. Bij twee van deze manieren wordt gebruik gemaakt van de Watson-Glaser test voor kritisch denken. Zoals besproken in de databeschrijving worden hiervan de percentielscores (4.1.1) en de stanine scores (4.1.2) geanalyseerd, dit omdat de totaalscore niet vergelijkbaar is tussen de verschillende versies van de Watson-Glaser test. Daarnaast is er aan de student gevraagd om zelf aan te geven hoe hij of zij zijn kritisch denkvermogen inschat. Deze subjectieve score van kritisch denken wordt geanalyseerd in sectie 4.1.3. Het is belangrijk om te melden dat de Watson-Glaser test voor kritisch denken een ander concept van kritisch denken benadrukt dan de subjectieve meting. De subjectieve vraag meet een kritische houding, waarbij de Watson-Glaser test meet hoe de student kritisch analyseert en verbanden legt. Hierdoor is het logisch om te verwachten dat een kritische houding stabieler zal blijven gedurende de testperiode dan kritische analyse vaardigheden, die wellicht meer vatbaar zijn voor verandering.

\subsubsection{Watson-Glaser test voor kritisch denken - percentielscore}

De Watson-Glaser percentielmeting laat de score zien van studenten voor kritisch denken gemeten op basis van hun antwoorden op statements en gevolgtrekkingen. Deze score is op percentielbasis gerangschikt voor alle studenten in dit onderzoek. De percentielscore wordt daarnaast ook gebaseerd op de scores van andere mensen die deze Watson-Glaser test gedaan hebben binnen hetzelfde referentieniveau. Hierdoor is de score van de studenten vergelijkbaar met iedereen die deze test heeft afgenomen binnen hetzelfde referentieniveau en is daardoor extern valide.

FIGUUR 11 Watson-Glaser kritisch denken score voor reguliere studenten en honoursstudenten naar nul- en eindmeting

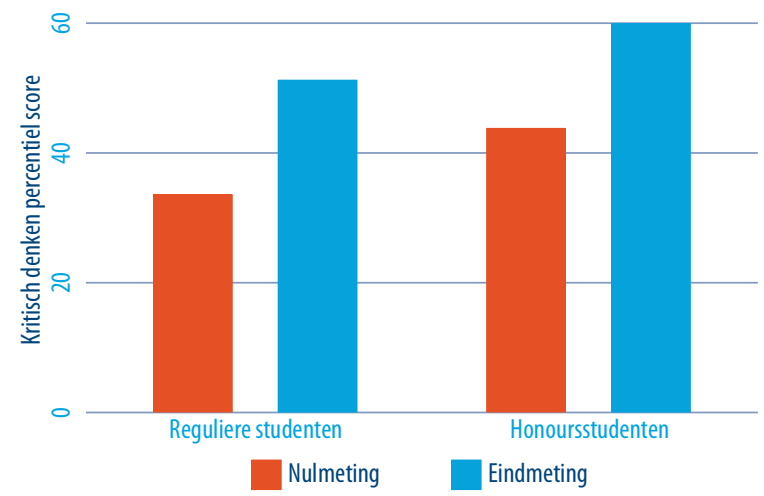

Bovenstaande Figuur 11 laat de ruwe scores zien bij de nulmeting (oranje) en de eindmeting (blauw) voor reguliere studenten (links) en honoursstudenten (rechts). Hier valt uit af te leiden dat honoursstudenten bij de nulmeting hoger scoren dan reguliere studenten, een score van 51.2 versus 33.6 respectievelijk. Daarnaast groeien zowel regu- 
liere studenten als honoursstudenten in hun kritische vaardigheden gedurende hun opleiding. Op het eerste oog lijkt de groei van reguliere studenten nagenoeg gelijk te zijn aan de groei van honoursstudenten. De gemiddelde eindscore voor reguliere studenten bedraagt 51.2 en voor honoursstudenten 59.9.

In Tabel 16 worden de resultaten van de geschatte multilevel repeated measuresmodellen weergegeven. Het multilevel repeated measures-model in $\mathrm{M}_{2}$ laat zien dat honoursstudenten geen significant sterkere groei hebben in kritisch denken dan reguliere studenten. Het interactie-effect is niet significant, ook als er controlevariabelen worden toegevoegd in de volgende modellen $M_{3} \mathrm{t} / \mathrm{m} \mathrm{M}_{5}$. Het niet-significante interactie-effect is echter wel negatief, wat inhoudt dat reguliere studenten een ietwat sterkere groei hebben meegemaakt vergeleken met honoursstudenten. Dit zou te verklaren kunnen zijn door een eventueel plafondeffect voor de honoursstudenten die al relatief hoog scoren op de Watson-Glaser test bij de nulmeting.

Wanneer er naar de achtergrondkenmerken van de studenten wordt gekeken valt op dat studenten met tenminste één ouder met Nederlandse achtergrond, en studenten die Nederlands spreken significant hoger scoren op de Watson-Glaser test. Extra analyses laten echter zien dat deze studenten geen significantere sterkere groei doormaken dan internationale studenten. Uit de persoonlijkheidskenmerken blijkt dat studenten die hoger scoren op neuroticisme, extraversie, openheid, zorgvuldigheid en risicopreferentie significant lager scoren op kritisch denken. Daarnaast blijkt uit de motivatiekenmerken dat studenten die minder consistent zijn in hun inzet, significant lager scoren op de Watson-Glaser test.

FIGUUR 12 Groei in Watson-Glaser percentielscore voor reguliere studenten en honoursstudenten

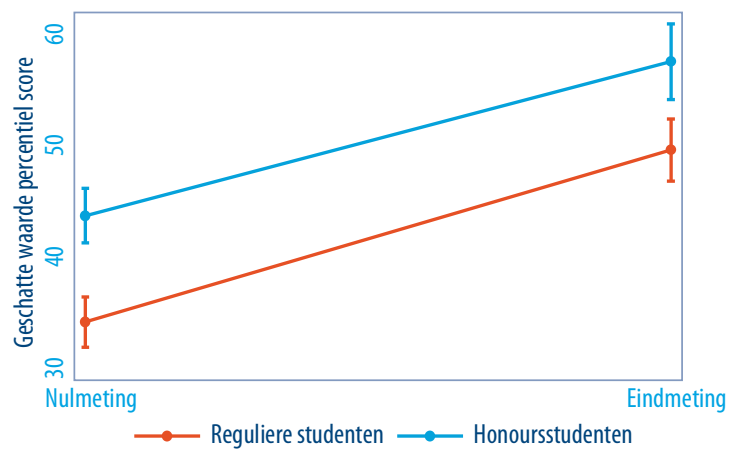

In Figuur 12 wordt de groei van de vaardigheid kritisch denken gemeten met de WatsonGlaser test weergegeven. Links in de figuur staat de nulmeting, en rechts de eindmeting. De lijn geeft de groei in score weer tussen de twee metingen. Wanneer we kijken naar de groei die studenten meemaken gedurende hun bacheloropleiding zien we dat zowel reguliere studenten als honoursstudenten een positieve groei in kritisch denken ervaren. De groei van reguliere studenten lijkt net iets sterker te zijn dan de groei van 
honoursstudenten, maar dit kan te verklaren zijn door plafondeffecten (honoursstudenten scoorden bij de nulmeting al relatief hoog). De verschillen in de groei van reguliere studenten en honoursstudenten zijn niet significant.

TABEL 16 Repeated measures-model van Watson-Glaser kritisch denken percentielscore

\begin{tabular}{|c|c|c|c|c|c|}
\hline & M1 & M2 & M3 & M4 & M5 \\
\hline Honoursstudenten (ref.=reguliere studenten) & $9.675^{* * *}$ & $10.088^{* * *}$ & $9.549^{* * *}$ & $7.489^{* * *}$ & $9.036^{* * *}$ \\
\hline Eindmeting (ref.=nulmeting) & $15.019^{* * *}$ & $15.609^{* * *}$ & $15.437^{* * *}$ & $15.152^{* * *}$ & $15.361^{* * *}$ \\
\hline Honoursstudenten * eindmeting & & -1.461 & -1.612 & -1.981 & -1.483 \\
\hline Cohort 2018-19 (ref.=cohort 2017-18) & & & $-3.443^{* *}$ & -1.850 & $-3.346^{* *}$ \\
\hline \multicolumn{6}{|l|}{ Achtergrondkenmerken van de student } \\
\hline \multicolumn{6}{|l|}{ Herkomst van de student (ref.=anders) } \\
\hline Tenminste één ouder van Nederlandse afkomst & & & & $12.303^{* * *}$ & \\
\hline \multicolumn{6}{|l|}{ Gesproken taal thuis (ref.=anders) } \\
\hline Nederlandse taal & & & & $16.782^{* * *}$ & \\
\hline \multicolumn{6}{|l|}{ Hoogste opleidingsniveau van de ouders (ref.=W0) } \\
\hline Basisonderwijs \& VMBO & & & & $-7.452^{* *}$ & \\
\hline HAVO, VWO \& MBO & & & & -1.953 & \\
\hline $\mathrm{HBO}$ & & & & -2.253 & \\
\hline \multicolumn{6}{|l|}{ Inkomen van de ouders (ref.=modaal) } \\
\hline Beneden modaal & & & & 0.702 & \\
\hline Boven modaal & & & & $4.245^{* *}$ & \\
\hline \multicolumn{6}{|l|}{ Motivatiekenmerken van de student } \\
\hline Intrinsieke motivatie & & & & & 2.119 \\
\hline Extrinsieke motivatie & & & & & -0.949 \\
\hline Consistentie van inzet & & & & & $-4.144^{* * *}$ \\
\hline Doorzettingsvermogen & & & & & -1.185 \\
\hline \multicolumn{6}{|l|}{ Persoonlijkheidskenmerken van de student } \\
\hline Neuroticisme & & & & & $-2.995^{* * *}$ \\
\hline Extraversie & & & & & $-2.312^{* *}$ \\
\hline Openheid & & & & & $-3.493^{* * *}$ \\
\hline Inschikkelijkheid & & & & & -0.110 \\
\hline Zorgvuldigheid & & & & & $-4.523^{* * *}$ \\
\hline Zelf-effectiviteit & & & & & $11.272^{* * *}$ \\
\hline Risicopreferentie & & & & & $-1.752^{* * *}$ \\
\hline Controle voor verschil tussen instellingen (fixed effects) & Nee & Nee & Ja & Ja & Ja \\
\hline Constant & $33.935^{* * *}$ & $33.739^{* * *}$ & $39.586^{* * *}$ & $26.673^{* * *}$ & $67.205^{* * *}$ \\
\hline $\mathrm{N}$ & 1506 & 1506 & 1506 & 1291 & 1492 \\
\hline
\end{tabular}

${ }^{*} p<0.1,{ }^{* *} p<0.05,{ }^{* * *} p<0.01$

\subsubsection{Watson-Glaser test voor kritisch denken - stanine-score}

DeWatson-Glaser stanine is de gestandaardiseerde score die studenten hebben behaald op de kritisch denken-vraagstukken. De score op kritisch denken is omgezet naar een gestandaardiseerde schaal die gemeten is binnen de normgroep waarin de test is afgenomen. Hierdoor is de score van de studenten vergelijkbaar met iedereen die deze test heeft afgenomen binnen hetzelfde referentieniveau en is daardoor extern valide. 
Onderstaande figuur laat de ruwe scores zien bij de nulmeting (oranje) en de eindmeting (blauw) voor reguliere studenten (links) en honoursstudenten (rechts). Uit Figuur 13 kan worden afgeleid dat de beginwaarde van honoursstudenten (4.5) hoger ligt dan de beginwaarde van reguliere studenten (3.8). Op de eindmeting scoren reguliere studenten gemiddeld 5 punten en honoursstudenten 5.6 punten. De groei van alle studenten tussen de beginmeting en eindmeting is nagenoeg gelijk, maar voor alle studenten positief.

FIGUUR 13 Watson-Glaser stanine-score voor reguliere studenten en honoursstudenten naar nulen eindmeting

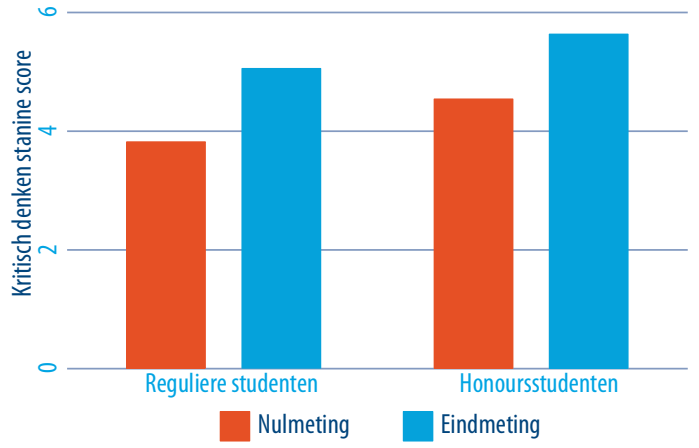

Uit de repeated measures multilevel-analyse (Tabel 17) en de bijbehorende marginsplot (Figuur 14) blijkt dat het beginniveau van honoursstudenten hoger ligt dan dat van de reguliere studenten, wat duidt op een selectie-effect. Honoursstudenten hebben duidelijk hogere kritisch denken-vaardigheden gemeten op de Watson-Glaser kritisch denken stanine score. Zowel reguliere studenten als honoursstudenten scoren significant hoger op de eindmeting dan op de nulmeting. Gedurende de bacheloropleiding groeien gemiddeld genomen alle studenten in hun kritisch denken-vaardigheden. De regressiecoëfficiënt van de interactie honoursstudenten*eindmeting is negatief, maar niet significant.

Als er naar de achtergrondkenmerken van de student wordt gekeken, blijkt dat studenten met tenminste één ouder met Nederlandse achtergrond, en studenten die Nederlands spreken significant hoger scoren op de Watson-Glaser test. Als wordt gekeken naar de motivatiekenmerken van de studenten blijkt dat consistentere studenten significant lager scoren. Uit de persoonlijkheidskenmerken blijkt dat studenten die hoger scoren op neuroticisme, extraversie, openheid, zorgvuldigheid en risicopreferentie significant lager scoren dan studenten die hier laag op scoren. Echter studenten die hoger scoren op zelf-effectiviteit scoren significant hoger op de kritisch denken test. In alle modellen scoren studenten significant hoger op de eindmeting dan op de beginmeting.

In Figuur 14 wordt de groei van de Watson-Glaser stanine score weergegeven. Uit deze figuur kan de groei van de studenten worden afgelezen, links staat de score op de nulmeting en rechts de score op de eindmeting. Het blijkt dat zowel reguliere als honoursstudenten een groei ervaren in hun kritisch denken stanine score. Het verschil in de groei tussen reguliere studenten en honoursstudenten is echter niet significant in deze modellen. 
FIGUUR 14 Groei in Watson-Glaser stanine score voor reguliere studenten en honoursstudenten

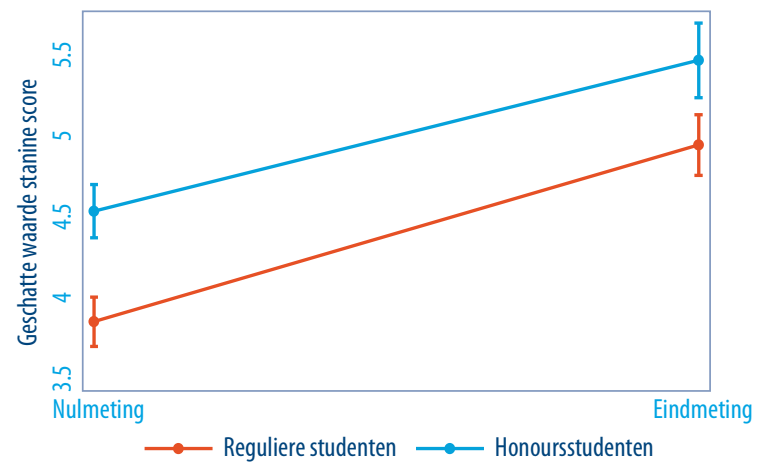

TABEL 17 Repeated measures-model van Watson-Glaser kritisch denken stanine-score

\begin{tabular}{|c|c|c|c|c|c|}
\hline & M1 & M2 & M3 & M4 & M5 \\
\hline Honoursstudenten (ref.=reguliere studenten) & $0.670^{* * *}$ & $0.712^{* * *}$ & $0.684^{* * *}$ & $0.549^{* * *}$ & $0.644^{* * *}$ \\
\hline Eindmeting (ref.=nulmeting) & $1.042^{* * *}$ & $1.101^{* * *}$ & $1.092^{* * *}$ & $1.093^{* * *}$ & $1.086^{* * *}$ \\
\hline Honoursstudenten * eindmeting & & -0.146 & -0.160 & -0.206 & -0.151 \\
\hline Cohort 2018-19 (ref.=cohort 2017-18) & & & $-0.248^{* *}$ & -0.142 & $-0.247^{* *}$ \\
\hline \multicolumn{6}{|l|}{ Achtergrondkenmerken van de student } \\
\hline \multicolumn{6}{|l|}{ Herkomst van de student (ref.=anders) } \\
\hline Tenminste één ouder van Nederlandse afkomst & & & & $0.868^{* * *}$ & \\
\hline \multicolumn{6}{|l|}{ Gesproken taal thuis (ref.=anders) } \\
\hline Nederlandse taal & & & & $1.063^{* * *}$ & \\
\hline \multicolumn{6}{|l|}{ Opleidingsniveau ouders (ref.=W0) } \\
\hline Basisonderwijs \& VMBO & & & & $-0.572^{* *}$ & \\
\hline HAVO, VWO \& MBO & & & & -0.109 & \\
\hline HBO & & & & -0.177 & \\
\hline \multicolumn{6}{|l|}{ Inkomen ouders (ref.=modaal) } \\
\hline Beneden modaal & & & & 0.093 & \\
\hline Boven modaal & & & & $0.289^{*}$ & \\
\hline \multicolumn{6}{|l|}{ Motivatiekenmerken van de student } \\
\hline Intrinsieke motivatie & & & & & 0.159 \\
\hline Extrinsieke motivatie & & & & & -0.072 \\
\hline Consistentie van inzet & & & & & $-0.271^{* * *}$ \\
\hline Doorzettingsvermogen & & & & & -0.091 \\
\hline \multicolumn{6}{|l|}{ Persoonlijkheidskenmerken van de student } \\
\hline Neuroticisme & & & & & $-0.194^{* * *}$ \\
\hline Extraversie & & & & & $-0.143^{* *}$ \\
\hline Openheid & & & & & $-0.218^{* * *}$ \\
\hline Inschikkelijkheid & & & & & -0.033 \\
\hline Zorgvuldigheid & & & & & $-0.287^{* * *}$ \\
\hline Zelf-effectiviteit & & & & & $0.757^{* * *}$ \\
\hline Risicopreferentie & & & & & $-0.122^{* * *}$ \\
\hline Controle voor verschil tussen instellingen (fixed effects) & Nee & Nee & $\mathrm{Ja}$ & $\mathrm{Ja}$ & $\mathrm{Ja}$ \\
\hline Constant & $3.848^{* * *}$ & $3.828^{* * *}$ & $4.137^{* * *}$ & $3.268^{* * *}$ & $5.927^{* * *}$ \\
\hline $\mathrm{N}$ & 1506 & 1506 & 1506 & 1291 & 1492 \\
\hline
\end{tabular}

${ }^{*} p<0.1,{ }^{* *} p<0.05,{ }^{* * *} p<0.01$ 


\subsubsection{Kritisch denken subjectieve meting}

De subjectieve kritisch denken-meting laat zien hoe studenten zichzelf scoren op basis van vijf statements over kritisch denken gedurende de opleiding. Deze subjectieve kritisch denken-score meet kritisch denken met betrekking tot de studie, opleiding en lesmateriaal. De statements die hierbij gebruikt zijn, zijn besproken in het databeschrijvingshoofdstuk.

Onderstaand Figuur 15 laat de ruwe scores zien bij de nulmeting (oranje) en de eindmeting (blauw) voor reguliere studenten (links) en honoursstudenten (rechts). Hier valt te zien dat reguliere en honoursstudenten gemiddeld vrijwel gelijke inschattingen geven van hun kritisch denken-niveau en de studenten nauwelijks groei hebben doorgemaakt op deze uitkomstmaat. Dit ondersteunt het idee dat de subjectieve meting een ander aspect van kritisch denken meet dan de Watson-Glaser test. De subjectieve kritisch denken-meting is stabieler over tijd.

FIGUUR 15 Subjectieve kritisch denken-score voor reguliere studenten en honoursstudenten naar nul- en eindmeting

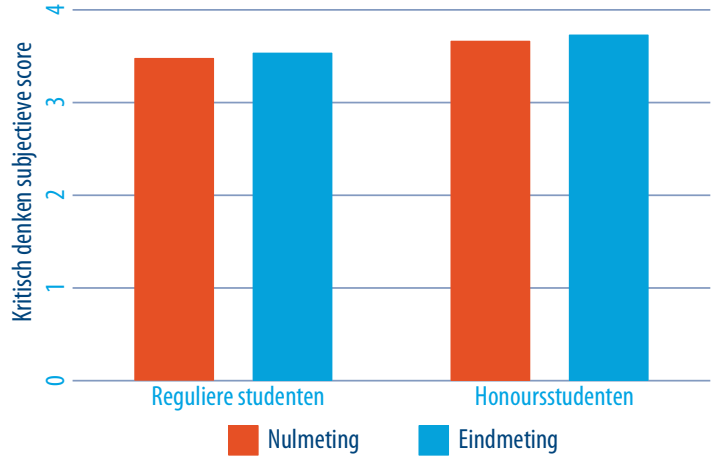

In Tabel 18 worden de resultaten weergegeven van de repeated measures multilevelanalyses. Als eerste blijkt dat honoursstudenten significant hoger scoren dan reguliere studenten, en gemiddeld genomen scoren alle studenten significant hoger op de eindmeting dan op de nulmeting. Echter blijkt dat het interactie-effect van de groei in kritisch denken niet significant is en dat de groei tussen de nul- en eindmeting niet sterker is voor honoursstudenten dan voor reguliere studenten.

Uit het vierde model blijkt dat studenten die thuis Nederlands spreken significant lager scoren op de subjectieve kritisch denken score vergeleken met studenten die thuis andere talen spreken, verder halen studenten met ouders met relatief lage inkomens hogere scores op de subjectieve kritisch denken meting dan studenten waarvan de ouders modaal verdienen. Andere kenmerken van de ouders en migratieachtergrond hebben geen invloed op de score op kritisch denken. Daarnaast hebben moti- 
vatie en persoonlijkheidskenmerken een invloed op de behaalde scores. Intrinsiek gemotiveerde studenten zijn kritischer en studenten met hoger doorzettingsvermogen zijn ook kritischer. Echter, extrinsiek gemotiveerde studenten en studenten die minder consistent zijn in hun interesses scoren lager op deze kritisch denken-meting. Persoonlijkheidskenmerken zoals openheid, inschikkelijkheid en zelf-effectiviteit hebben een significante relatie met de score op de subjectieve kritisch denken-meting, waarbij openheid en zelf-effectiviteit positieve invloed hebben en inschikkelijkheid een negatieve invloed heeft op de behaalde scores.

Figuur 16 laat de groei zien die studenten hebben meegemaakt op de subjectieve meting van kritisch denken. Reguliere studenten en honoursstudenten groeien beide licht tussen de nul- en eindmeting. Er is echter geen significant verschil in de sterkte van de groei tussen reguliere studenten en honoursstudenten. Al met al onderstreept dit opnieuw dat deze subjectieve meting stabieler is en minder groei kent dan de WatsonGlaser uitkomstmaten.

FIGUUR 16 Groei in subjectieve kritisch denken-score voor reguliere studenten en honoursstudenten

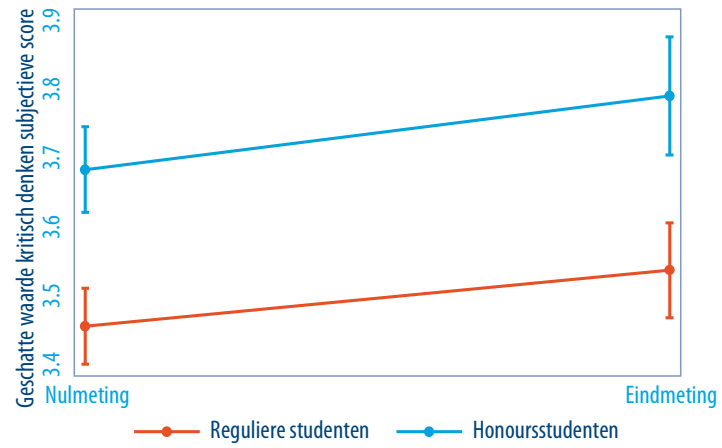


TABEL 18 Repeated measures-model van subjectieve kritisch denken-score

\begin{tabular}{|c|c|c|c|c|c|}
\hline & M1 & M2 & M3 & M4 & M5 \\
\hline Honoursstudenten (ref.=reguliere studenten) & $0.192^{* * *}$ & $0.186^{* * *}$ & $0.227^{* * *}$ & $0.214^{* * *}$ & $0.084^{* *}$ \\
\hline Eindmeting (ref.=nulmeting) & $0.089^{* * *}$ & $0.080^{* *}$ & $0.081^{* *}$ & $0.100^{* * *}$ & $0.087^{* * *}$ \\
\hline Honoursstudenten * eindmeting & & 0.024 & 0.026 & 0.004 & 0.027 \\
\hline Cohort 2018-19 (ref.=cohort 2017-18) & & & 0.028 & 0.003 & -0.001 \\
\hline \multicolumn{6}{|l|}{ Achtergrondkenmerken van de student } \\
\hline \multicolumn{6}{|l|}{ Herkomst van de student (ref.=anders) } \\
\hline Tenminste één ouder van Nederlandse afkomst & & & & -0.036 & \\
\hline \multicolumn{6}{|l|}{ Gesproken taal thuis (ref.=anders) } \\
\hline Nederlandse taal & & & & $-0.171^{*}$ & \\
\hline \multicolumn{6}{|l|}{ Opleidingsniveau ouders (ref.=W0) } \\
\hline Basisonderwijs \& VMBO & & & & -0.165 & \\
\hline HAVO, VWO \& MBO & & & & -0.001 & \\
\hline $\mathrm{HBO}$ & & & & -0.028 & \\
\hline \multicolumn{6}{|l|}{ Inkomen ouders (ref.=modaal) } \\
\hline Beneden modaal & & & & $0.153^{*}$ & \\
\hline Boven modaal & & & & 0.078 & \\
\hline \multicolumn{6}{|l|}{ Motivatiekenmerken van de student } \\
\hline Intrinsieke motivatie & & & & & $0.386^{* * *}$ \\
\hline Extrinsieke motivatie & & & & & $-0.040^{*}$ \\
\hline Consistentie van inzet & & & & & $-0.047^{*}$ \\
\hline Doorzettingsvermogen & & & & & $0.065^{*}$ \\
\hline \multicolumn{6}{|l|}{ Persoonlijkheidskenmerken van de student } \\
\hline Neuroticisme & & & & & -0.015 \\
\hline Extraversie & & & & & -0.028 \\
\hline Openheid & & & & & $0.218^{* * *}$ \\
\hline Inschikkelijkheid & & & & & $-0.064^{* * *}$ \\
\hline Zorgvuldigheid & & & & & -0.004 \\
\hline Zelf-effectiviteit & & & & & $0.236^{* * *}$ \\
\hline Risicopreferentie & & & & & 0.014 \\
\hline Controle voor verschil tussen instellingen (fixed effects) & Nee & Nee & Ja & Ja & Ja \\
\hline Constant & $3.473^{* * *}$ & $3.476^{* * *}$ & $3.508^{* * *}$ & $3.573^{* * *}$ & $0.724^{* * *}$ \\
\hline $\mathrm{N}$ & 1545 & 1545 & 1545 & 1334 & 1544 \\
\hline
\end{tabular}

${ }^{*} p<0.1,{ }^{* *} p<0.05,{ }^{* * *} p<0.01$

\subsection{Creativiteit}

In dit onderzoek wordt zowel een objectieve en subjectieve benadering van creativiteit gemeten. De objectieve benadering van creativiteit wordt aan de hand van de Alternate Uses Test (AUT) gemeten waaruit drie maatstaven komen: "fluency", "flexibility" en "perseverance". Deze zijn besproken in het databeschrijvingshoofdstuk. Kort samengevat meet "fluency" het aantal correcte antwoorden op de test. De uitkomsten voor "fluency" worden besproken in sectie 4.3.1. "Flexibility" meet het aantal categorieën waarbinnen correcte antwoorden vallen, dit om te meten of studenten in verschillende 
richtingen kunnen denken. De uitkomsten hiervan worden gerapporteerd in sectie 4.3.2. Als laatste meet "perseverance" een soort doorzettingsvermogen, waarbij de ratio tussen het aantal correcte antwoorden en het aantal categorieën wordt genomen als uitkomstmaat. "Perseverance"-uitkomsten worden in sectie 4.3.3 besproken. De subjectieve meting is gebaseerd op enkele statements. Deze statements meten creativiteit van de studenten op een tiental dimensies, zoals creativiteit in kunst, of creativiteit in wiskunde. Deze subjectieve creativiteitsscores worden besproken in 4.3.4.

\subsubsection{Alternate Uses Test voor creativiteit - fluency-score}

Onderstaande Figuur 17 laat de ruwe scores zien bij de nulmeting (oranje) en de eindmeting (blauw) voor reguliere studenten (links) en honoursstudenten (rechts). Hier valt te zien dat het beginniveau van reguliere studenten en honoursstudenten nagenoeg gelijkligt waarbij honoursstudenten iets hoger scoren, 12.5 goede antwoorden gemiddeld voor reguliere studenten versus gemiddeld 13.6 goede antwoorden voor honoursstudenten. Honoursstudenten hebben een ietwat sterkere groei meegemaakt naar de eindmeting toe vergeleken met de reguliere studenten (17.8 versus 19.3).

FIGUUR 17 Creativiteit fluency-score voor reguliere studenten en honoursstudenten naar nul- en eindmeting

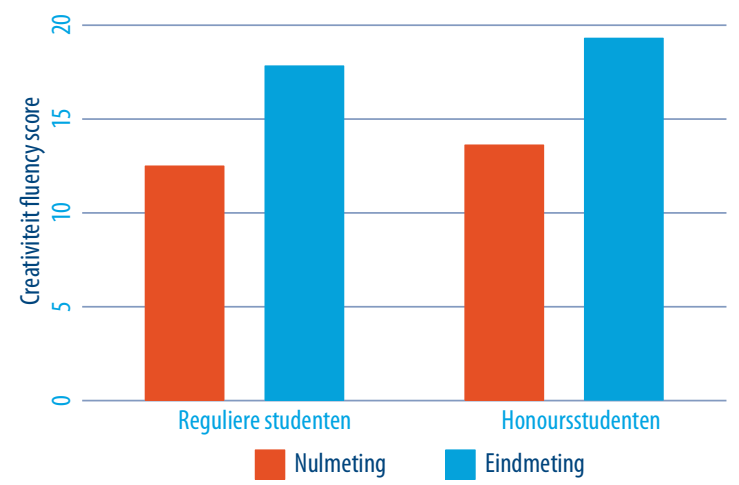

In Tabel 19 staan de uitkomsten voor de multilevel repeated measures-analyse voor de creativiteitsscore "fluency". Uit de resultaten blijkt dat honoursstudenten hoger scoren dan reguliere studenten, en dit is een significant verschil. Daarnaast scoren gemiddeld genomen alle studenten hoger op de eindmeting dan op de nulmeting. Gemiddeld behalen alle studenten ongeveer 5 extra goede antwoorden op de eindmeting vergeleken met de nulmeting. Als er wordt gekeken naar de belangrijkste variabele, de groei-indicator, is het interactie-effect niet significant, waaruit blijkt dat honoursstudenten geen sterkere groei in creativiteit doormaken dan reguliere studenten. De groei van honoursstudenten is echter niet significant sterker in vergelijking met reguliere studenten. 
Sommige kenmerken van de ouders en migratieachtergrond hebben een significante invloed op de fluency-score van creativiteit. Zo hebben studenten waarvan tenminste één ouder uit Nederland komt hogere scores vergeleken met studenten waarvan beide ouders uit het buitenland komen. Daarnaast hebben studenten met ouders waarvan het opleidingsniveau relatief laag is (basisonderwijs en vmbo) een significant lagere score ten opzichte van studenten waarvan de ouders universitair geschoold zijn. Studenten waarvan de ouders als hoogste opleidingsniveau hbo hebben, scoren ook significant lager dan studenten waarvan de ouders universitair geschoold zijn. Enkele motivatie- en persoonlijkheidskenmerken hebben ook een significante invloed op de fluency-score. Studenten met hoger doorzettingsvermogen zijn creatiever dan studenten die iets minder hoog scoren op doorzettingsvermogen. En studenten waarvan de consistentie in interesse lager is, scoren ook lager op deze test. Studenten die hoger scoren op zorgvuldigheid scoren lager op de creativiteitsmaat, en studenten die hoger scoren op zelfeffectiviteit en openheid scoren hoger op de creativiteitstest.

Figuur 18 laat de groei zien voor reguliere studenten en honoursstudenten op de creativiteitsuitkomst. Dit figuur laat zien dat zowel reguliere als honoursstudenten groeien in hun creativiteit gedurende de periode tussen de nul- en eindmeting. Echter, zoals ook in Tabel 19 te zien is, is er geen significant verschil in de groei tussen reguliere studenten en honoursstudenten. De positieve coëfficiënt van het interactie-effect is nauwelijks waar te nemen in het figuur. Beide groepen studenten maken een nagenoeg gelijke groei mee.

FIGUUR 18 Groei in creativiteit fluency-score voor reguliere studenten en honoursstudenten

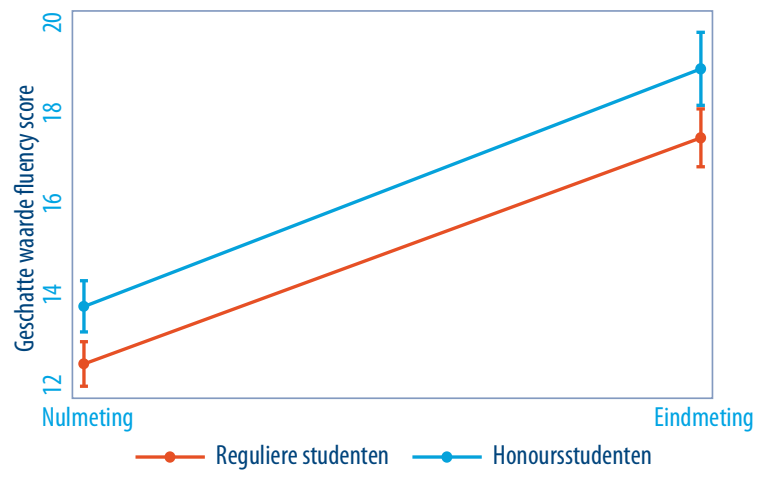


TABEL 19 Repeated measures-model van creativiteit - fluency-score

\begin{tabular}{|c|c|c|c|c|c|}
\hline & M1 & M2 & M3 & M4 & M5 \\
\hline Honoursstudenten (ref.=reguliere studenten) & $1.214^{* * *}$ & $1.124^{* * *}$ & $1.270^{* * *}$ & $0.827^{* *}$ & $1.242^{* * *}$ \\
\hline Eindmeting (ref.=nulmeting) & $5.147^{* * *}$ & $5.025^{* * *}$ & $4.990^{* * *}$ & $4.805^{* * *}$ & $5.000^{* * *}$ \\
\hline Honoursstudenten * eindmeting & & 0.312 & 0.249 & 0.211 & 0.250 \\
\hline Cohort 2018-19 (ref.=cohort 2017-18) & & & $-1.015^{* * *}$ & $-1.093^{* * *}$ & $-0.986^{* * *}$ \\
\hline \multicolumn{6}{|l|}{ Achtergrondkenmerken van de student } \\
\hline \multicolumn{6}{|l|}{ Herkomst van de student (ref.=anders) } \\
\hline \multicolumn{2}{|l|}{ Tenminste één ouder van Nederlandse afkomst } & & & $1.923^{*}$ & \\
\hline \multicolumn{6}{|l|}{ Gesproken taal thuis (ref.=anders) } \\
\hline Nederlandse taal & & & & 0.623 & \\
\hline \multicolumn{6}{|l|}{ Opleidingsniveau ouders (ref.=W0) } \\
\hline Basisonderwijs \& VMBO & & & & $-2.840^{* * *}$ & \\
\hline HAVO, VWO \& MBO & & & & -0.608 & \\
\hline HBO & & & & $-1.124^{* *}$ & \\
\hline \multicolumn{6}{|l|}{ Inkomen ouders (ref.=modaal) } \\
\hline Beneden modaal & & & & 0.456 & \\
\hline Boven modaal & & & & 0.174 & \\
\hline \multicolumn{6}{|l|}{ Motivatiekenmerken student } \\
\hline Intrinsieke motivatie & & & & & -0.048 \\
\hline Extrinsieke motivatie & & & & & -0.210 \\
\hline Consistentie van inzet & & & & & $-0.652^{* *}$ \\
\hline Doorzettingsvermogen & & & & & $0.672^{*}$ \\
\hline \multicolumn{6}{|l|}{ Persoonlijkheidskenmerken } \\
\hline Neuroticisme & & & & & -0.190 \\
\hline Extraversie & & & & & 0.186 \\
\hline Openheid & & & & & $0.373^{*}$ \\
\hline Inschikkelijkheid & & & & & -0.393 \\
\hline Zorgvuldigheid & & & & & $-0.819^{* *}$ \\
\hline Zelf-effectiviteit & & & & & $1.395^{* * *}$ \\
\hline Risicopreferentie & & & & & -0.149 \\
\hline Controle voor verschil tussen instellingen (fixed effects) & Nee & Nee & Ja & Ja & Ja \\
\hline Constant & $12.457^{* * *}$ & $12.497^{* * *}$ & $13.035^{* * *}$ & $12.798^{* * *}$ & $12.201^{* * *}$ \\
\hline $\mathrm{N}$ & 1564 & 1564 & 1564 & 1340 & 1553 \\
\hline
\end{tabular}

${ }^{*} p<0.1,{ }^{* *} p<0.05,{ }^{* * *} p<0.01$ 


\subsubsection{Alternate Uses Test voor creativiteit - flexibility-score}

De Alternate Uses Test (AUT) flexibility meet het aantal verschillende categorieën en dimensies waarbinnen een student een correct antwoord heeft gegeven. De goede antwoorden die de studenten hebben gegeven op de Alternate Uses Test zijn geclassificeerd in een aantal categorieën. Hoe hoger de flexibility-score, hoe ruimer de student heeft gedacht en in hoe meer categorieën de student een correct antwoord heeft gegeven.

Onderstaande Figuur 19 laat de ruwe scores zien bij de nulmeting (oranje) en de eindmeting (blauw) voor reguliere studenten en honoursstudenten. Hier valt te zien dat reguliere en honoursstudenten een relatief kleine groei in "flexibility" meemaken. Het ruimer denken en in meer categorieën denken is een eigenschap die minder groei meemaakt gedurende de bachelor vergeleken met het aantal correcte antwoorden ("fluency"). Reguliere studenten scoren op de nulmeting gemiddeld een 11.6 en honoursstudenten een 12.3, op de eindmeting scoren reguliere studenten 12.2 en honoursstudenten 12.8. Gemiddeld is er in 0.6 categorieën meer correcte antwoorden gegeven.

FIGUUR 19 Creativiteit flexibility-score voor reguliere studenten en honoursstudenten naar nul-en eindmeting

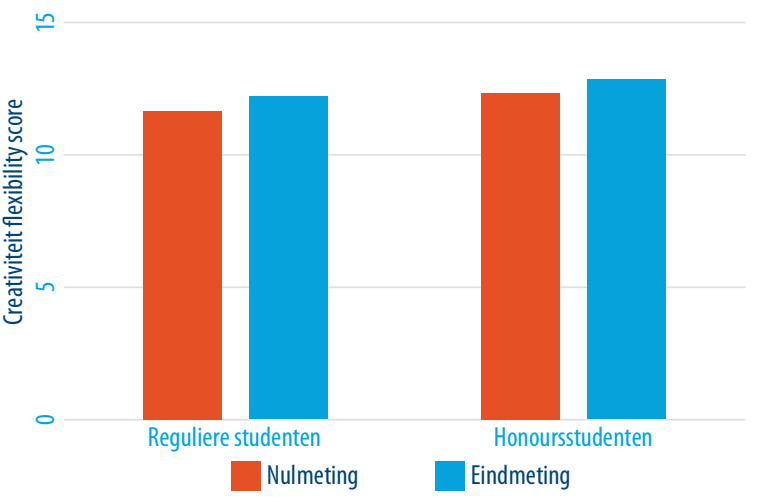

De uitkomsten van het multilevel repeated measures-model voor de flexibility-score worden weergegeven in Tabel 20. Hieruit blijkt een significant verschil tussen honoursstudenten en reguliere studenten op de flexibility-score, waar honoursstudenten hoger scoren. Er is echter geen significante relatie met de eindmeting; gemiddeld genomen scoren alle studenten niet significant hoger op de eindmeting dan op de nulmeting. Hieraan gerelateerd is er dan ook geen significant verschil tussen de beide groepen in de groei van de studenten.

Enkele kenmerken van de ouders en migratieachtergrond hebben invloed op de flexibility-score. Studenten waarvan tenminste één van de ouders van Nederlandse afkomst is, scoren significant hoger vergeleken met studenten waarvan beide ouders uit het buitenland komen. Studenten met ouders waarvan het opleidingsniveau relatief laag is 
(basisonderwijs en vmbo + havo, vwo en mbo) hebben een lagere score ten opzichte van studenten waarvan de ouders universitair geschoold zijn. Er is geen significant verschil op de flexibility-score voor studenten waarvan de ouders een hbo-opleiding hebben gevolgd vergeleken met wo-opleidingen. Enkele motivatie- en persoonlijkheidskenmerken hebben een significante relatie met de creativiteitsscore. Studenten met hogere consistentie van interesse zijn minder creatief dan studenten die iets minder hoog scoren op consistentie van interesse. Studenten die hoger scoren op zelf-effectiviteit scoren lager op de creativiteitsmaat, en studenten die hoger scoren op risicopreferentie en neuroticisme hebben lagere creativiteitsscores.

Figuur 20 geeft de groei op de flexibility-score weer voor reguliere en honoursstudenten. Hier kunnen we nogmaals zien dat er niet significant hoger gescoord wordt op de eindmeting dan op de nulmeting. Daarnaast zien we ook dat de groei van honoursstudenten en reguliere studenten niet van elkaar afwijken en er geen significant sterkere groei voor honoursstudenten te zien is. De groei op de flexibility-score van de Alternate Uses Test is minimaal.

FIGUUR 20 Groei in flexibility-score voor reguliere studenten en honoursstudenten

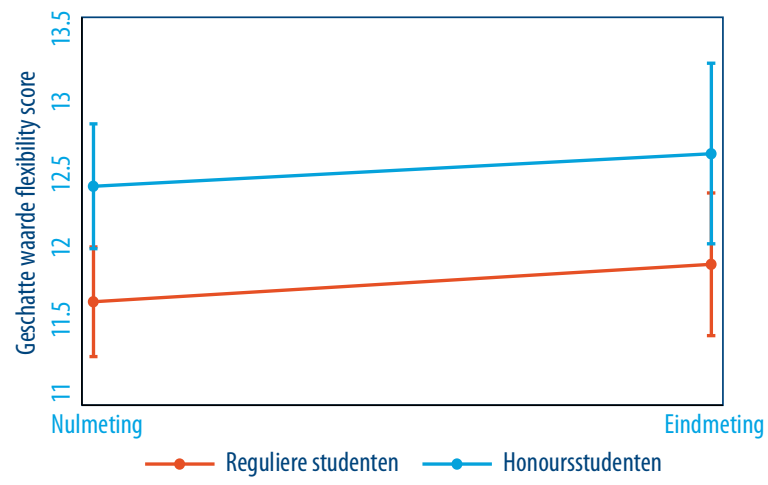

TABEL 20 Repeated measures-model van creativiteit - flexibility-score

\begin{tabular}{|c|c|c|c|c|c|}
\hline & M1 & M2 & M3 & M4 & M5 \\
\hline Honoursstudenten (ref.=reguliere studenten) & $0.677^{* *}$ & $0.689^{* *}$ & $0.792^{* * *}$ & 0.521 & $0.757^{* *}$ \\
\hline Eindmeting (ref.=nulmeting) & 0.174 & 0.191 & 0.257 & 0.147 & 0.261 \\
\hline Honoursstudenten * eindmeting & & -0.043 & -0.032 & -0.037 & -0.030 \\
\hline Cohort 2018-19 (ref.=cohort 2017-18) & & & $-3.396^{* * *}$ & $-3.394^{* * *}$ & $-3.393^{* * *}$ \\
\hline \multicolumn{6}{|l|}{ Achtergrondkenmerken van de student } \\
\hline \multicolumn{6}{|l|}{ Herkomst van de student (ref.=anders) } \\
\hline \multicolumn{2}{|l|}{ Tenminste één ouder van Nederlandse afkomst } & & & $1.000^{*}$ & \\
\hline \multicolumn{6}{|l|}{ Gesproken taal thuis (ref.=anders) } \\
\hline Nederlandse taal & & & & 0.411 & \\
\hline \multicolumn{6}{|l|}{ Opleidingsniveau ouders (ref.=W0) } \\
\hline Basisonderwijs \& VMBO & & & & $-2.576^{* * *}$ & \\
\hline
\end{tabular}


TABEL 20 Repeated measures-model van creativiteit - flexibility-score

\begin{tabular}{|c|c|c|c|c|c|}
\hline & M1 & M2 & M3 & M4 & M5 \\
\hline HAVO, VWO \& MBO & & & & $-0.695^{*}$ & \\
\hline HBO & & & & -0.461 & \\
\hline \multicolumn{6}{|l|}{ Inkomen ouders (ref.=modaal) } \\
\hline Beneden modaal & & & & -0.075 & \\
\hline Boven modaal & & & & 0.032 & \\
\hline \multicolumn{6}{|l|}{ Motivatiekenmerken van de student } \\
\hline Intrinsieke motivatie & & & & & 0.226 \\
\hline Extrinsieke motivatie & & & & & -0.187 \\
\hline Consistentie van inzet & & & & & $-0.649 * * *$ \\
\hline Doorzettingsvermogen & & & & & 0.223 \\
\hline \multicolumn{6}{|l|}{ Persoonlijkheidskenmerken van de student } \\
\hline Neuroticisme & & & & & $-0.270^{*}$ \\
\hline Extraversie & & & & & 0.218 \\
\hline Openheid & & & & & 0.220 \\
\hline Inschikkelijkheid & & & & & -0.188 \\
\hline Zorgvuldigheid & & & & & -0.424 \\
\hline Zelf-effectiviteit & & & & & $0.943^{* *}$ \\
\hline Risicopreferentie & & & & & $-0.132^{*}$ \\
\hline Controle voor verschil tussen instellingen (fixed effects) & Nee & Nee & Ja & $\mathrm{Ja}$ & $\mathrm{Ja}$ \\
\hline Constant & $11.668^{* * *}$ & $11.663^{* * *}$ & $14.651^{* * *}$ & $14.738^{* * *}$ & $14.425^{* * *}$ \\
\hline $\mathrm{N}$ & 1564 & 1564 & 1564 & 1340 & 1553 \\
\hline
\end{tabular}

\subsubsection{Alternate Uses Test voor creativiteit - perseverance-score}

De Alternate Uses Test (AUT) perseverance meet het doorzettingsvermogen op de creativiteitstest. Het wordt berekend als het aantal antwoorden per unieke categorie waarbinnen de student denkt.

Figuur 21 laat de ruwe scores zien bij de nulmeting (oranje) en de eindmeting (blauw) voor reguliere studenten en honoursstudenten. De score op de nulmeting van zowel reguliere studenten als honoursstudenten ligt lager dan de score op hun eindmeting. Reguliere studenten scoren op de nulmeting 5.7 en op de eindmeting 7.7. Honoursstudenten scoren op de nulmeting 6.2 en op de eindmeting 8.1. 
FIGUUR 21 Creativiteit "perseverance" score voor reguliere studenten en honoursstudenten naar nul- en eindmeting

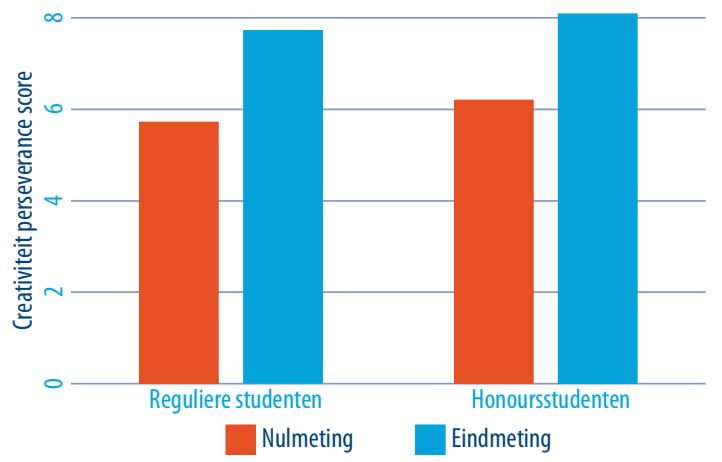

Uit de repeated measures multilevel-analyse (Tabel 21) blijkt dat honoursstudenten significant hoger scoren dan reguliere studenten op perseverance. Daarnaast blijkt ook dat zowel reguliere studenten als honoursstudenten significant hoger scoren op de eindmeting dan op de nulmeting. Verder blijkt uit het interactie-effect van studenten*meting dat honoursstudenten niet een significant andere groei doormaken dan reguliere studenten.

Achtergrondkenmerken van de student hebben in sommige gevallen invloed op de perseverance-score van creativiteit.Studenten mettenminsteéén oudervan Nederlandse afkomst scoren significant hoger dan studenten die geen Nederlandse ouders hebben. Studenten met ouders waarvan het opleidingsniveau relatief laag is (basisonderwijs en vmbo) hebben een lagere score ten opzichte van studenten waarvan de ouders universitair geschoold zijn en studenten waarvan de ouders een hbo-opleiding hebben gevolgd ondervinden ook, in kleinere mate, een significant negatieve relatie op de perseverancescore. Enkele motivatie- en persoonlijkheidskenmerken hebben een significante relatie met de perseverance-score. Studenten die hoger scoren op zorgvuldigheid en intrinsieke motivatie scoren lager op de creativiteitsmaat, en studenten die hoger scoren op zelf-effectiviteit hebben hogere creativiteitsscores.

Figuur 22 laat de groei van de studenten zien op de perseverance-score voor reguliere studenten en honoursstudenten tussen de nul- en eindmeting. Zoals eerder in de tekst al is besproken, laat deze plot zien dat er geen significant verschil is in de groei die studenten meemaken. 
FIGUUR 22 Groei in perseverance-score voor reguliere studenten en honoursstudenten

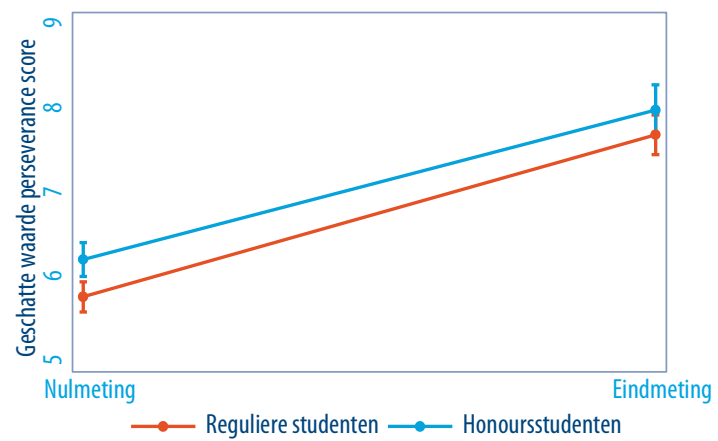

TABEL 21 Repeated measures-model van creativiteit - perseverance-score

\begin{tabular}{|c|c|c|c|c|c|}
\hline & M1 & M2 & M3 & M4 & M5 \\
\hline Honoursstudenten (ref.=reguliere studenten) & $0.442^{* * *}$ & $0.479 * * *$ & $0.442^{* * *}$ & $0.338^{* * *}$ & $0.454^{* * *}$ \\
\hline Eindmeting (ref.=nulmeting) & $1.896^{* * *}$ & $1.944^{* * *}$ & $1.923^{* * *}$ & $1.815^{* * *}$ & $1.912^{* * *}$ \\
\hline Honoursstudenten * eindmeting & & -0.123 & -0.148 & -0.127 & -0.157 \\
\hline Cohort 2018-19 (ref.=cohort 2017-18) & & & $1.232^{* * *}$ & $1.285^{* * *}$ & $1.294^{* * *}$ \\
\hline \multicolumn{6}{|l|}{ Achtergrondkenmerken van de student } \\
\hline \multicolumn{6}{|l|}{ Herkomst van de student (ref.=anders) } \\
\hline Tenminste één ouder van Nederlandse afkomst & & & & $0.523^{* *}$ & \\
\hline \multicolumn{6}{|l|}{ Gesproken taal thuis (ref.=anders) } \\
\hline Nederlandse taal & & & & 0.355 & \\
\hline \multicolumn{6}{|l|}{ Opleidingsniveau ouders (ref.=W0) } \\
\hline Basisonderwijs \& VMBO & & & & $-0.782^{* * *}$ & \\
\hline HAVO, VWO \& MBO & & & & -0.193 & \\
\hline HBO & & & & $-0.567^{* * *}$ & \\
\hline \multicolumn{6}{|l|}{ Inkomen ouders (ref.=modaal) } \\
\hline Beneden modaal & & & & 0.184 & \\
\hline Boven modaal & & & & -0.138 & \\
\hline \multicolumn{6}{|l|}{ Motivatiekenmerken van de student } \\
\hline Intrinsieke motivatie & & & & & $-0.204^{*}$ \\
\hline Extrinsieke motivatie & & & & & 0.054 \\
\hline Consistentie van inzet & & & & & -0.043 \\
\hline Doorzettingsvermogen & & & & & 0.152 \\
\hline \multicolumn{6}{|l|}{ Persoonlijkheidskenmerken van de student } \\
\hline Neuroticisme & & & & & 0.055 \\
\hline Extraversie & & & & & -0.064 \\
\hline Openheid & & & & & -0.015 \\
\hline Inschikkelijkheid & & & & & -0.080 \\
\hline Zorgvuldigheid & & & & & $-0.339^{* * *}$ \\
\hline Zelf-effectiviteit & & & & & $0.562^{* * *}$ \\
\hline Risicopreferentie & & & & & -0.030 \\
\hline Controle voor verschil tussen instellingen (fixed effects) & Nee & Nee & Ja & $\mathrm{Ja}$ & $\mathrm{Ja}$ \\
\hline Constant & $5.738^{* * *}$ & $5.722^{* * *}$ & $4.792^{* * *}$ & $4.751^{* * *}$ & $4.650^{* * *}$ \\
\hline $\mathrm{N}$ & 1564 & 1564 & 1564 & 1340 & 1553 \\
\hline
\end{tabular}

${ }^{*} \mathrm{p}<0.1,{ }^{* *} \mathrm{p}<0.05,{ }^{* * *} \mathrm{p}<0.05$ 


\subsubsection{Creativiteit subjectieve meting}

De subjectieve meting van creativiteit vraagt studenten of ze zichzelf zien als creatief op tien verschillende onderdelen zoals wiskunde, kunst en taal. Hieruit komt een creativiteitsscore die breder kijkt dan de Alternate Uses Test en toepasbaar is op meerdere dimensies.

Onderstaande figuur laat de ruwe scores zien bij de nulmeting (oranje) en de eindmeting (blauw) voor reguliere studenten en honoursstudenten. Hier valt te zien dat reguliere en honoursstudenten hun creativiteitsniveau als ongeveer hetzelfde beschouwen en er weinig groei plaatsvindt tussen de eerste meting en tweede meting. Reguliere studenten scoren op de nulmeting 3.31 en op de eindmeting 3.30. Honoursstudenten scoren op de nulmeting 3.28 en op de eindmeting 3.29. Deze subjectieve score voor creativiteit blijkt vrij stabiel over de tijd.

FIGUUR 23 Subjectieve score voor creativiteit voor reguliere studenten en honoursstudenten naar nul- en eindmeting

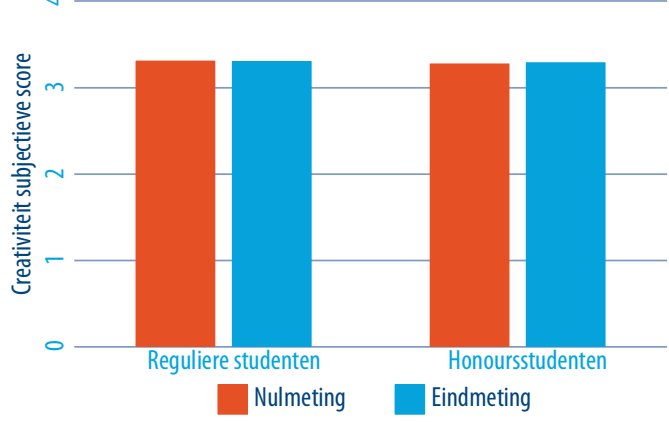

Tabel 22 geeft de resultaten weer van het multilevel repeated measures model voor de subjectieve creativiteitsscore. De nul- en eindmeting van de studenten zijn genest binnen het individu. Hierdoor kan individuele groei gemodelleerd worden. Zoals al gezien kon worden in Figuur 23, bevestigen de uitkomsten van de regressie-analyse dat honoursstudenten niet significant hoger scoren dan reguliere studenten, en dat studenten niet significant beter scoren op de eindmeting dan op de beginmeting. Het interactie-effect van honoursstudenten*eindmeting is ook niet significant, en onderstreept dat er geen verschil in groei is voor honoursstudenten vergeleken met reguliere studenten.

Achtergrondgegevens van de ouders hebben een invloed op de subjectieve creativiteit score, waarbij studenten waarvan tenminste één van de ouders van Nederlandse afkomst is een significant lagere score hebben vergeleken met andere studenten. Daarnaast scoren studenten waarvan het opleidingsniveau van de ouders relatief laag is (basisonderwijs en vmbo) significant lager dan studenten waarvan de ouders universi- 
tair zijn geschoold. Diverse motivatiekenmerken hebben een significante relatie met de subjectieve creativiteitsscore. Studenten die extrinsiek gemotiveerd zijn, scoren lager op de subjectieve creativiteitsscore, en studenten met hoog doorzettingsvermogen scoren hoger. Daarnaast hebben enkele persoonlijkheidskenmerken ook een significante invloed waarbij extraverte, open, zorgvuldige, risico prefererende en zelf-effectieve studenten significant hoger scoren op subjectieve creativiteitsmaat.

Figuur 24 laat de groei zien in de subjectieve creativiteitsscore voor reguliere studenten en honoursstudenten. Zoals al te zien was in Figuur 23, scoren de reguliere studenten gemiddeld lager op de eindmeting dan op de beginmeting. De honoursstudenten scoren gemiddeld hoger op de eindmeting. Hierdoor is in het figuur een kruising van de groei te zien voor de studenten. Al met al zijn de verschillen echter zeer klein. Opmerkelijk is dat de subjectieve score voor creativiteit veel stabieler lijkt te zijn dan de objectieve scores van de Alternate Uses Test. Studenten groeien dus wel in hun creativiteit, ondanks dat dit niet naar voren komt in de subjectieve meting.

FIGUUR 24 Groei in de subjectieve score van creativiteit voor reguliere studenten en honoursstudenten

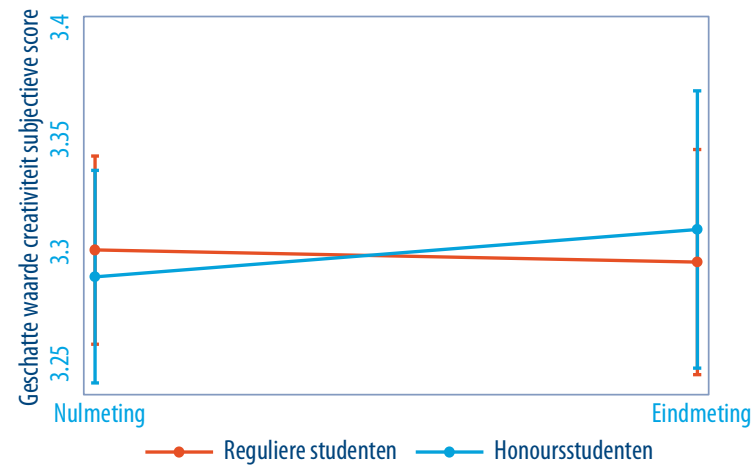

TABEL 22 Repeated measures-model van creativiteit subjectieve meting

\begin{tabular}{|c|c|c|c|c|c|}
\hline & M1 & M2 & M3 & M4 & M5 \\
\hline Honoursstudenten (ref.=reguliere studenten) & -0.024 & -0.031 & -0.012 & -0.023 & $-0.073^{* * *}$ \\
\hline Eindmeting (ref.=nulmeting) & 0.005 & -0.005 & -0.005 & -0.008 & 0.003 \\
\hline Honoursstudenten * eindmeting & & 0.028 & 0.026 & 0.041 & 0.024 \\
\hline Cohort 2018-19 (ref.=cohort 2017-18) & & & 0.036 & 0.023 & 0.015 \\
\hline \multicolumn{6}{|l|}{ Achtergrondkenmerken van de student } \\
\hline \multicolumn{6}{|l|}{ Herkomst van de student (ref.=anders) } \\
\hline Tenminste één ouder van Nederlandse afkomst & & & & $-0.220^{* * *}$ & \\
\hline \multicolumn{6}{|l|}{ Gesproken taal thuis (ref.=anders) } \\
\hline Nederlandse taal & & & & 0.066 & \\
\hline \multicolumn{6}{|l|}{ Opleidingsniveau ouders (ref.=W0) } \\
\hline Basisonderwijs \& VMBO & & & & $-0.140^{*}$ & \\
\hline HAVO, VWO \& MBO & & & & 0.017 & \\
\hline
\end{tabular}


TABEL 22 Repeated measures-model van creativiteit subjectieve meting

\begin{tabular}{|c|c|c|c|c|c|}
\hline & M1 & M2 & M3 & M4 & M5 \\
\hline HBO & & & & -0.031 & \\
\hline \multicolumn{6}{|l|}{ Inkomen ouders (ref.=modaal) } \\
\hline Beneden modaal & & & & -0.027 & \\
\hline Boven modaal & & & & 0.012 & \\
\hline \multicolumn{6}{|l|}{ Motivatiekenmerken van de student } \\
\hline Intrinsieke motivatie & & & & & 0.005 \\
\hline Extrinsieke motivatie & & & & & $-0.034^{* *}$ \\
\hline Consistentie van inzet & & & & & -0.027 \\
\hline Doorzettingsvermogen & & & & & $0.102^{* * *}$ \\
\hline \multicolumn{6}{|l|}{ Persoonlijkheidskenmerken van de student } \\
\hline Neuroticisme & & & & & 0.022 \\
\hline Extraversie & & & & & $0.065^{* * *}$ \\
\hline Openheid & & & & & $0.276^{* * *}$ \\
\hline Inschikkelijkheid & & & & & -0.004 \\
\hline Zorgvuldigheid & & & & & $0.065^{* * *}$ \\
\hline Zelf-effectiviteit & & & & & $0.102^{* * *}$ \\
\hline Risicopreferentie & & & & & $0.030^{* * *}$ \\
\hline Controle voor verschil tussen instellingen (fixed effects) & Nee & Nee & Ja & Ja & Ja \\
\hline Constant & $3.305^{* * *}$ & $3.309^{* * *}$ & $3.274^{* * *}$ & $3.350^{* * *}$ & $1.025^{* * *}$ \\
\hline $\mathrm{N}$ & 1539 & 1539 & 1539 & 1333 & 1538 \\
\hline
\end{tabular}

${ }^{*} p<0.1,{ }^{* *} p<0.05,{ }^{* * *} p<0.01$

\subsection{Leiderschap}

De subjectieve meting van leiderschap vraagt studenten of ze de leiding nemen in de groep en zich bekommeren om de medegroepsleden, op basis van 5 vragen zoals o.a. 'I $k$ probeer iedereen in een groep het gevoel te geven dat ze erbij horen' of 'Ik vind het moeilijk anderen te bewegen om met elkaar samen te werken'.

Figuur 25 laat de ruwe scores zien bij de nulmeting (oranje) en de eindmeting (blauw) voor reguliere studenten en honoursstudenten. Hier valt te zien dat de startwaarde van reguliere en honoursstudenten op ongeveer hetzelfde niveau ligt tijdens de nulmeting (3.86 versus 3.87 respectievelijk op een schaal van 1 tot 5 ). Vervolgens halen reguliere studenten een iets hogere score op de eindmeting (3.95) dan honoursstudenten (3.91). 
FIGUUR 25 Leiderschapsscore voor reguliere studenten en honoursstudenten naar nul- en eindmeting

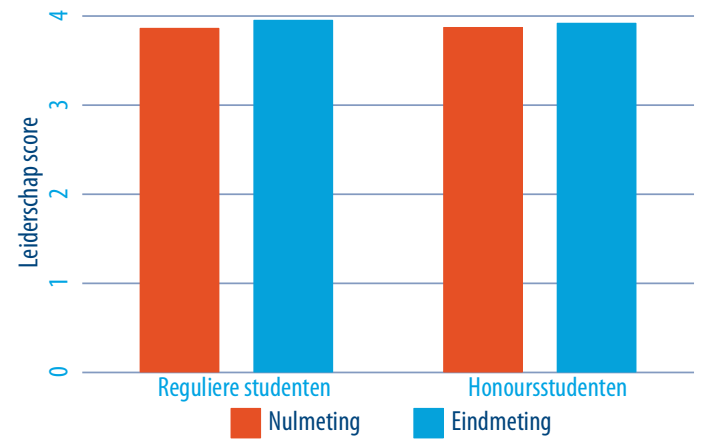

De uitkomsten van de repeated measures multilevel-analyse zijn te vinden in Tabel 23, Hieruit blijkt dat op de eindmeting significant hoger wordt gescoord voor zowel reguliere studenten als voor honoursstudenten. Honoursstudenten scoren niet significant hoger dan reguliere studenten, behalve als er gecontroleerd wordt voor persoonlijkheidskenmerken en motivatiekenmerken in Model M5. De groei van de studenten is niet significant verschillend voor reguliere studenten en honoursstudenten. Uit de coëfficiënt voor de interactie tussen honoursstudenten*eindmeting blijkt dat de groei voor honoursstudenten minder sterk is (negatieve coëfficiënt) vergeleken met reguliere studenten. Het verschil tussen reguliere en honoursstudenten op de beginmeting van leiderschap is kleiner geworden na 1,5 jaar studeren. Alle studenten hebben een groei meegemaakt op leiderschap skills, waarbij honoursstudenten niet significant sterker gegroeid zijn dan reguliere studenten.

Kenmerken van de ouders en migratieachtergrond hebben in beperkte mate invloed op de score op de leiderschapsvaardigheden van studenten. Het inkomen van de ouders heeft een invloed op leiderschap waarbij studenten waarvan de ouders beneden modaal verdienen lager scoren op leiderschap dan studenten waarvan de ouders modaal verdienen. Meerdere motivatie- en persoonlijkheidskenmerken hebben significante relaties met de leiderschapsscore. Studenten die consistent zijn in hun interesses en doorzetters zijn, scoren hoger op leiderschap. Daarnaast scoren extraverte, open, zorgvuldige, inschikkelijke, risicoprefererende en zelf-effectieve studenten hoger op leiderschap dan hun medestudenten die lager scoren op deze persoonlijkheidskenmerken.

Figuur 26 toont de groei in de leiderschapskwaliteiten van reguliere studenten en honoursstudenten. Zowel reguliere studenten als honoursstudenten groeien in hun leiderschapskwaliteiten en het verschil tussen reguliere en honoursstudenten wordt kleiner tussen de nul- en eindmeting. De groei is echter niet significant verschillend voor reguliere of honoursstudenten. 
FIGUUR 26 Groei in leiderschap voor reguliere studenten en honoursstudenten

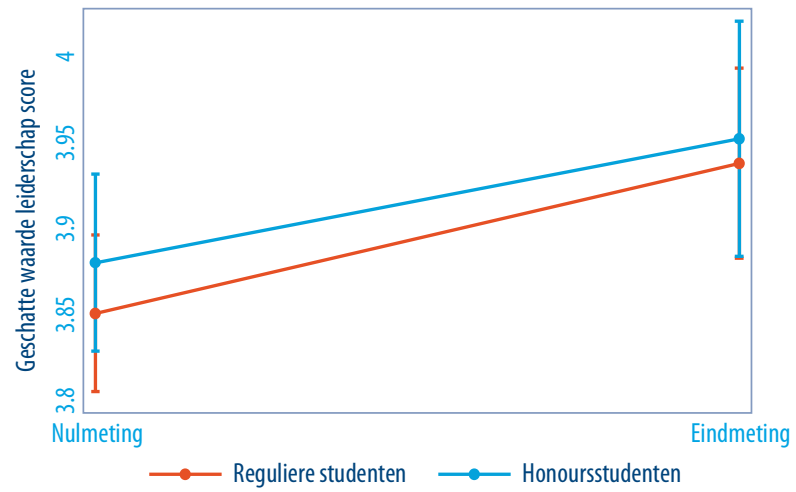

TABEL 23 Repeated measures-model van leiderschap

\begin{tabular}{|c|c|c|c|c|c|}
\hline & M1 & M2 & M3 & M4 & M5 \\
\hline Honoursstudenten (ref.=reguliere studenten) & 0.007 & 0.011 & 0.029 & 0.038 & $-0.062^{* *}$ \\
\hline Eindmeting (ref.=nulmeting) & $0.079^{* * *}$ & $0.084^{* * *}$ & $0.087^{* * *}$ & $0.091^{* * *}$ & $0.084^{* * *}$ \\
\hline Honoursstudenten * eindmeting & & -0.013 & -0.015 & -0.017 & -0.010 \\
\hline Cohort 2018-19 (ref.=cohort 2017-18) & & & 0.017 & 0.007 & 0.023 \\
\hline \multicolumn{6}{|l|}{ Achtergrondkenmerken van de student } \\
\hline \multicolumn{6}{|l|}{ Herkomst van de student (ref.=anders) } \\
\hline \multicolumn{2}{|l|}{ Tenminste één ouder van Nederlandse afkomst } & & & -0.092 & \\
\hline \multicolumn{6}{|l|}{ Gesproken taal thuis (ref.=anders) } \\
\hline Nederlandse taal & & & & 0.055 & \\
\hline \multicolumn{6}{|l|}{ Opleidingsniveau ouders (ref.=W0) } \\
\hline Basisonderwijs \& VMBO & & & & 0.106 & \\
\hline HAVO, VWO \& MBO & & & & 0.045 & \\
\hline HBO & & & & -0.008 & \\
\hline \multicolumn{6}{|l|}{ Inkomen ouders (ref.=modaal) } \\
\hline Beneden modaal & & & & $-0.179^{* * *}$ & \\
\hline Boven modaal & & & & 0.049 & \\
\hline \multicolumn{6}{|l|}{ Motivatiekenmerken van de student } \\
\hline Intrinsieke motivatie & & & & & 0.036 \\
\hline Extrinsieke motivatie & & & & & 0.018 \\
\hline Consistentie van inzet & & & & & $0.036^{*}$ \\
\hline Doorzettingsvermogen & & & & & $0.050^{*}$ \\
\hline \multicolumn{6}{|l|}{ Persoonlijkheidskenmerken van de student } \\
\hline Neuroticisme & & & & & -0.017 \\
\hline Extraversie & & & & & $0.176^{* * *}$ \\
\hline Openheid & & & & & $0.056^{* * *}$ \\
\hline Inschikkelijkheid & & & & & $0.127^{* * *}$ \\
\hline Zorgvuldigheid & & & & & $0.069^{* *}$ \\
\hline Zelf-effectiviteit & & & & & $0.266^{* * *}$ \\
\hline Risicopreferentie & & & & & $0.015^{* *}$ \\
\hline Controle voor verschil tussen instellingen (fixed effects) & Nee & Nee & Ja & $\mathrm{Ja}$ & Ja \\
\hline Constant & $3.862^{* * *}$ & $3.861^{* * *}$ & $3.778^{* * *}$ & $3.767^{* * *}$ & $0.725^{* * *}$ \\
\hline $\mathrm{N}$ & 1547 & 1547 & 1547 & 1334 & 1544 \\
\hline
\end{tabular}




\subsection{Politieke betrokkenheid}

De subjectieve meting van politieke betrokkenheid vraagt studenten of ze enkele politieke activiteiten ondernemen zoals stemmen, protesteren of bijvoorbeeld contact opnemen met politieke leiders. Deze maatstaaf is zo geconstrueerd dat zowel studenten van Nederlandse afkomst als internationale studenten kunnen aangeven of ze politiek betrokken zijn en dat internationale studenten niet lager scoren puur door het feit dat ze niet kunnen deelnemen aan lokale verkiezingen in Nederland.

Onderstaande figuur laat de ruwe scores zien bij de nulmeting (oranje) en de eindmeting (blauw) voor reguliere studenten en honoursstudenten. Hier valt te zien dat de startwaarde van reguliere en honoursstudenten verschilt waarbij de reguliere studenten (0.48) hoger scoren dan honoursstudenten (0.45) op een schaal van o tot 1. Voor alle studenten geldt dat ze minder politiek betrokken zijn in de eindmeting vergeleken met de nulmeting. Reguliere studenten scoren op de eindmeting gemiddeld 0.45 en honoursstudenten scoren gemiddeld 0.43 .

FIGUUR 27 Politieke betrokkenheid voor reguliere studenten en honoursstudenten naar nul- en eindmeting

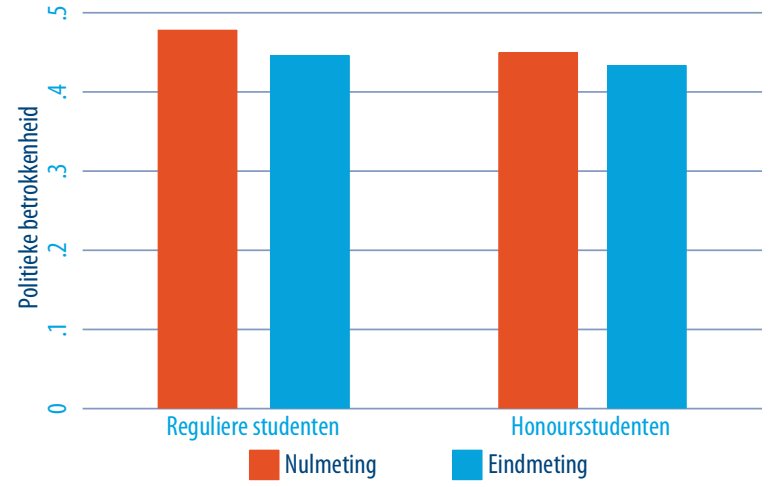

Tabel 24 laat de resultaten van het multilevel repeated measures-model zien voor politieke betrokkenheid. Tussen de nulmeting en eindmeting zijn nauwelijks significante verschillen tussen de studenten. Daarnaast scoren honoursstudenten en reguliere studenten niet significant anders op politieke betrokkenheid. Uit de resultaten van het interactie-effect blijkt dat honoursstudenten geen significant sterkere groei doormaken dan reguliere studenten.

Migratieachtergrond van de student heeft invloed op de politieke betrokkenheid van studenten. Studenten die tenminste één ouder hebben van Nederlandse afkomst zijn minder politiek betrokken dan andere studenten. Internationale studenten zijn significant meer betrokken bij politiek vergeleken met Nederlandse studenten. Motivatiekenmerken zoals extrinsieke motivatie en doorzettingsvermogen zijn signifi- 
cant gerelateerd aan politieke betrokkenheid; extraverte studenten zijn minder politiek betrokken en doorzetters zijn meer politiek betrokken. Daarnaast hebben ook enkele persoonlijkheidskenmerken een significante invloed op leiderschap. Inschikkelijke studenten zijn minder politiek betrokken. Daarnaast scoren neurotische, extraverte en open studenten hoger op politieke betrokkenheid.

Figuur 28 laat de geschatte groei zien in politieke betrokkenheid voor reguliere studenten en honoursstudenten. In dit figuur is te zien dat zowel reguliere studenten als honoursstudenten iets meer politiek betrokken raken gedurende hun bacheloropleiding, waarbij honoursstudenten net iets meer politiek betrokken raken vergeleken met reguliere studenten. Het verschil in groei tussen beide groepen is echter niet significant.

FIGUUR 28 Groei in politieke betrokkenheid voor reguliere studenten en honoursstudenten

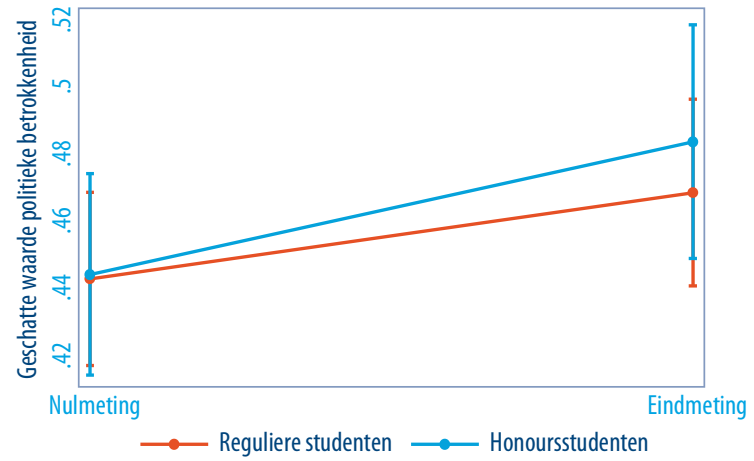

TABEL 24 Repeated measures-model van politieke betrokkenheid

\begin{tabular}{|c|c|c|c|c|c|}
\hline & M1 & M2 & M3 & M4 & M5 \\
\hline Honoursstudenten (ref.=reguliere studenten) & -0.018 & -0.025 & 0.001 & -0.011 & -0.007 \\
\hline Eindmeting (ref.=nulmeting) & 0.011 & 0.004 & $0.026^{*}$ & 0.020 & $0.027^{* *}$ \\
\hline Honoursstudenten * eindmeting & & 0.017 & 0.014 & 0.008 & 0.013 \\
\hline Cohort 2018-19 (ref.=cohort 2017-18) & & & $0.057^{* * *}$ & $0.037^{*}$ & $0.051^{* * *}$ \\
\hline \multicolumn{6}{|l|}{ Achtergrondkenmerken van de student } \\
\hline \multicolumn{6}{|l|}{ Herkomst van de student (ref.=anders) } \\
\hline Tenminste één ouder van Nederlandse afkomst & & & & $-0.061^{*}$ & \\
\hline \multicolumn{6}{|l|}{ Gesproken taal thuis (ref.=anders) } \\
\hline Nederlandse taal & & & & -0.031 & \\
\hline \multicolumn{6}{|l|}{ Opleidingsniveau ouders (ref.=W0) } \\
\hline Basisonderwijs \& VMBO & & & & -0.022 & \\
\hline HAVO, VWO \& MBO & & & & 0.018 & \\
\hline $\mathrm{HBO}$ & & & & 0.013 & \\
\hline \multicolumn{6}{|l|}{ Inkomen ouders (ref.=modaal) } \\
\hline Beneden modaal & & & & 0.013 & \\
\hline Boven modaal & & & & 0.013 & \\
\hline Motivatiekenmerken van de student & & & & & \\
\hline
\end{tabular}


TABEL 24 Repeated measures-model van politieke betrokkenheid

\begin{tabular}{|c|c|c|c|c|c|}
\hline & M1 & M2 & M3 & M4 & M5 \\
\hline Intrinsieke motivatie & & & & & 0.016 \\
\hline Extrinsieke motivatie & & & & & $-0.022^{*}$ \\
\hline Consistentie van inzet & & & & & -0.013 \\
\hline Doorzettingsvermogen & & & & & $0.034^{*}$ \\
\hline \multicolumn{6}{|l|}{ Persoonlijkheidskenmerken van de student } \\
\hline Neuroticisme & & & & & $0.023^{* *}$ \\
\hline Extraversie & & & & & $0.025^{* *}$ \\
\hline Openheid & & & & & $0.044^{* * *}$ \\
\hline Inschikkelijkheid & & & & & $-0.028^{* *}$ \\
\hline Zorgvuldigheid & & & & & 0.006 \\
\hline Zelf-effectiviteit & & & & & 0.021 \\
\hline Risicopreferentie & & & & & 0.005 \\
\hline Controle voor verschil tussen instellingen (fixed effects) & Nee & Nee & Ja & Ja & $\mathrm{Ja}$ \\
\hline Constant & $0.453^{* * *}$ & $0.456^{* * *}$ & $0.344^{* * *}$ & $0.398^{* * *}$ & -0.061 \\
\hline N & 1195 & 1195 & 1195 & 1036 & 1194 \\
\hline
\end{tabular}

\subsection{Studieresultaten}

In deze sectie wordt gekeken naar de studieresultaten die de studenten behalen gedurende hun bacheloropleiding. Er wordt naar meerdere uitkomstmaten gekeken: het gemiddelde cijfer voor de bachelor, het gemiddelde cijfer in het eerste, tweede en derde jaar van de studie, en het cijfer voor de bachelorscriptie. Deze verschillende uitkomstmaten zijn gebruikt om te kijken naar de ontwikkeling van studieresultaten die de studenten gedurende de bachelor meemaken.

Deze analyses zijn alleen uitgevoerd voor studenten van de Universiteit van Maastricht. Deze resultaten kunnen worden gezien als een casestudy over verschillen in (de ontwikkeling van) studieresultaten van reguliere studenten en honoursstudenten.

\subsubsection{Gemiddeld cijfer voor bachelor}

In deze analyse wordt gekeken naar het gemiddeld cijfer in het eerste jaar en deze wordt vergeleken met het gemiddeld cijfer over de gehele bachelor. In Figuur 29 wordt het gemiddelde cijfer van de gehele bachelor uitgesplitst naar de groep reguliere studenten en honoursstudenten. Dit cijfer is berekend aan de hand van alle vakken die de student heeft gehaald over de duur van de gehele bachelor. Het gemiddelde cijfer is voor honoursstudenten een 8,31 in het eerste jaar en een 7,97 voor de gehele bachelor, en voor reguliere studenten een 7,44 in het eerste jaar en voor de gehele bachelor een 7,25 . Hieruit blijkt dat honoursstudenten hoger scoren dan reguliere studenten, wat een aannemelijk verschil is. 
FIGUUR 29 Gemiddeld cijfer over gehele bachelor voor reguliere studenten en honoursstudenten vergeleken met gemiddeld cijfer in het eerste jaar

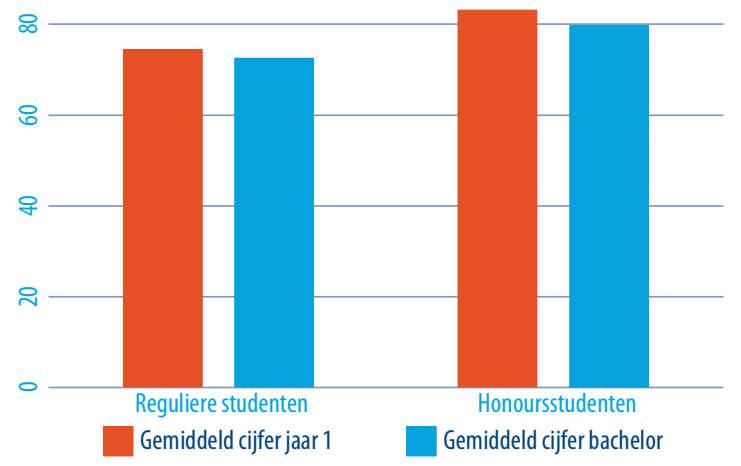

Tabel 25 laat de resultaten van het multilevel repeated measures-model zien voor de behaalde cijfers van de student. De eerste meting is het gemiddelde cijfer gedurende het eerste bachelorjaar, de tweede meting is het gemiddelde cijfer voor de gehele bacheloropleiding. Voor alle studenten geldt dat ze niet verschillend scoren op de nul- en eindmeting. Anders gezegd, er is geen significante verbetering van de cijfers ten opzichte van de nulmeting, maar honoursstudenten gaan het ook niet slechter doen door deelname aan excellentieprogramma's. Honoursstudenten scoren wel in het algemeen hoger dan reguliere studenten, en dit is een significant verschil. Uit het interactie-effect blijkt dat reguliere studenten een sterke significante groei meemaken in hun gemiddeld cijfer, terwijl honoursstudenten een lichte daling van hun gemiddeld cijfer zien. De licht negatieve groei voor honoursstudenten is mede verklaarbaar door de toelatingseis in Maastricht om deel te nemen aan een excellentieprogramma: studenten dienen in hun eerste jaar een gemiddeld cijfer van tenminste 8.0 te behalen om in aanmerking te komen in het honoursprogramma, en zetten daarom in het eerste jaar mogelijk extra in op het voldoen aan deze eis. Een lichte daling in cijfers in de jaren wijst daarom niet per se op een wezenlijke achteruitgang in studieresultaten.

In het vierde model wordt het gemiddeld eindexamencijfer van de middelbare school als extra controle toegevoegd. Hieruit blijkt dat studenten die hogere gemiddelde examencijfers op de middelbare school haalden, tijdens hun bachelor ook hogere cijfers halen, echter is de coëfficiënt klein, namelijk 0,03 cijferpunten. In het vierde en vijfde model worden achtergrondkenmerken van de student toegevoegd. Studenten die de Nederlandse taal thuis spreken, een indicator voor migratieachtergrond, scoren significant lagere cijfers vergeleken met studenten die andere talen thuis spreken. Motivatiekenmerken zoals intrinsieke motivatie en consistentie van interesse hebben een significante negatieve relatie met de behaalde cijfers van de studenten. Daarnaast hebben ook enkele persoonlijkheidskenmerken een significante relatie met de behaalde cijfers. Studenten die hoog scoren op openheid en risico preferentie halen significant lagere cijfers en studenten die hoog scoren op zorgvuldigheid en zelf-effectiviteit halen significant hogere cijfers. 
Figuur 30 laat de verwachte groei zien in de behaalde cijfers tussen de nul- en eindmeting voor reguliere studenten en honoursstudenten. In dit figuur is te zien dat reguliere studenten gemiddeld hogere cijfers gaan halen naarmate hun bacheloropleiding volgt, waar honoursstudenten een licht negatieve ontwikkeling van hun gemiddeld cijfer zien. Echter behalen honoursstudenten nog steeds hogere cijfers dan reguliere studenten.

FIGUUR 30 Groei in cijfers gedurende de bachelor voor reguliere studenten en honoursstudenten

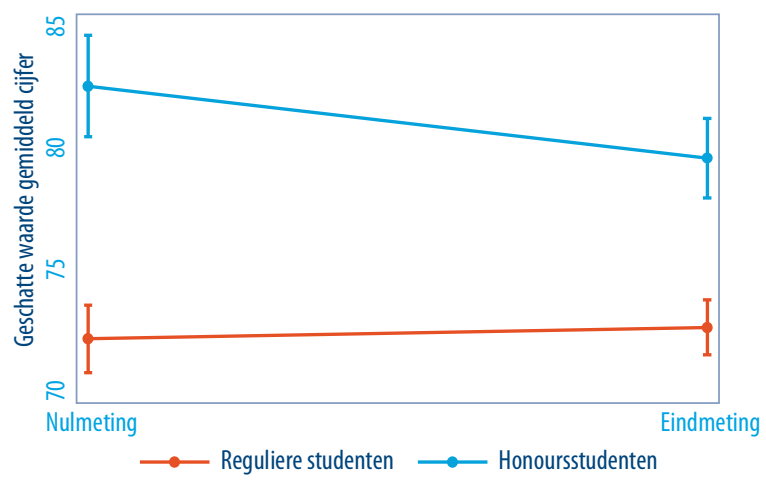

TABEL 25 Repeated measures-model voor gemiddelde cijfer gedurende bacheloropleiding

\begin{tabular}{|c|c|c|c|c|c|c|}
\hline & M1 & M2 & M3 & M4 & M5 & M6 \\
\hline Honoursstudenten (ref.=reguliere studenten) & $8.032^{* * *}$ & $10.642^{* * *}$ & $10.390^{* * *}$ & $8.829^{* * *}$ & $7.915^{* * *}$ & $8.282^{* * *}$ \\
\hline Eindmeting (ref.=nulmeting) & -0.662 & 0.460 & 0.472 & 0.460 & 0.114 & 0.521 \\
\hline Honoursstudenten * eindmeting & & $-3.467^{* * *}$ & $-3.433^{* * *}$ & $-3.449 * * *$ & $-2.956^{* * *}$ & $-3.443^{* * *}$ \\
\hline Cohort 2018-19 (ref.=cohort 2017-18) & & & $1.510^{*}$ & $1.494^{*}$ & $1.692^{*}$ & $1.528^{*}$ \\
\hline Examencijfer middelbare school & & & & $0.317^{* * *}$ & $0.311^{* * *}$ & $0.275^{* * *}$ \\
\hline \multicolumn{7}{|l|}{ Achtergrondkenmerken van de student } \\
\hline \multicolumn{7}{|l|}{ Herkomst van de student (ref.=anders) } \\
\hline Tenminste een ouder van Nederlandse afkomst & & & & & 2.357 & \\
\hline \multicolumn{7}{|l|}{ Gesproken taal thuis (ref.=anders) } \\
\hline Nederlandse taal & & & & & $-2.947^{*}$ & \\
\hline \multicolumn{7}{|l|}{ Opleidingsniveau ouders (ref.=W0) } \\
\hline Basisonderwijs \& VMBO & & & & & 1.037 & \\
\hline HAVO, VWO \& MBO & & & & & 1.352 & \\
\hline HBO & & & & & 0.686 & \\
\hline \multicolumn{7}{|l|}{ Inkomen ouders (ref.=modaal) } \\
\hline Beneden modaal & & & & & 1.386 & \\
\hline Boven modaal & & & & & $1.834^{*}$ & \\
\hline \multicolumn{7}{|l|}{ Motivatiekenmerken van de student } \\
\hline Intrinsieke motivatie & & & & & & $-1.323^{*}$ \\
\hline Extrinsieke motivatie & & & & & & 0.746 \\
\hline Consistentie van inzet & & & & & & $-1.454^{* *}$ \\
\hline Doorzettingsvermogen & & & & & & -0.338 \\
\hline Persoonlijkheidskenmerken van de student & & & & & & \\
\hline
\end{tabular}


TABEL 25 Repeated measures-model voor gemiddelde cijfer gedurende bacheloropleiding

\begin{tabular}{|c|c|c|c|c|c|c|}
\hline & M1 & M2 & M3 & M4 & M5 & M6 \\
\hline Neuroticisme & & & & & & -0.780 \\
\hline Extraversie & & & & & & -0.036 \\
\hline Openheid & & & & & & $-1.821^{* * * *}$ \\
\hline Inschikkelijkheid & & & & & & -0.413 \\
\hline Zorgvuldigheid & & & & & & $2.785^{* * *}$ \\
\hline Zelf-effectiviteit & & & & & & $2.204^{* *}$ \\
\hline Risicopreferentie & & & & & & $-0.977^{* * *}$ \\
\hline Constant & $72.909^{* * *}$ & $72.061^{* * *}$ & $71.393^{* * *}$ & $45.762^{* * *}$ & $45.297^{* * *}$ & $56.447^{* * *}$ \\
\hline N & 613 & 613 & 613 & 606 & 521 & 606 \\
\hline
\end{tabular}

\subsubsection{Scriptiecijfer}

Het gemiddeld cijfer voor de bachelorscriptie wordt in deze sectie vergeleken met het gemiddeld cijfer van het eerste jaar in de bachelor. De bachelorscriptie wordt vaak gezien als belangrijke indicator voor het afronden van de bacheloropleiding, en is hierdoor een belangrijke uitkomstmaat. In Figuur 31 wordt gekeken naar het cijfer voor de bachelorscriptie. Hierbij blijkt dat er een klein verschil is in het behaalde cijfer wanneer we reguliere studenten vergelijken met honoursstudenten. Reguliere studenten scoren gemiddeld een 7,74 en honoursstudenten een 8,08. Bij reguliere studenten ligt het gemiddelde scriptiecijfer iets hoger dan het gemiddelde cijfer in jaar 1, terwijl voor honoursstudenten het omgekeerde geldt.

FIGUUR 31 Gemiddeld scriptiecijfer voor reguliere studenten en honoursstudenten vergeleken met gemiddeld cijfer in het eerste jaar

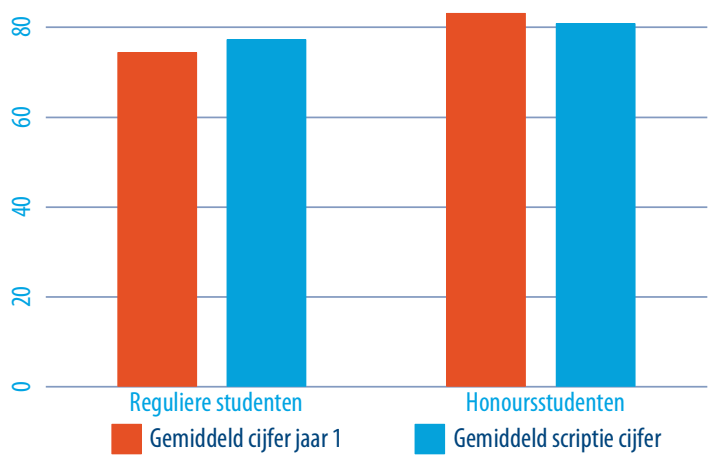

In Tabel 26 staan de uitkomsten van de multilevel repeated measures-analyse naar het behaalde scriptiecijfer weergegeven. Wanneer we kijken naar het scriptiecijfer als uitkomstmaat kunnen we de volgende conclusies trekken. Net zoals bij het gemiddelde cijfer van de studenten, wordt bij het scriptiecijfer duidelijk dat er een licht negatieve groei is voor honoursstudenten. Dit is mede verklaarbaar door de toelatingseis in 
Maastricht om deel te nemen aan een excellentieprogramma. Daarnaast is de bachelorscriptie niet volledig representatief voor andere vakken in onderwijsprogramma's.

Er wordt als extra controle het gemiddelde examencijfer van de middelbare school toegevoegd, waaruit blijkt dat er een significant positieve relatie tussen het scriptiecijfer en het examencijfer op de middelbare school is. Wanneer er wordt gekeken naar de achtergrondkenmerken van de student zien we dat de herkomst van de student een positieve relatie heeft met behaalde cijfers waar studenten met tenminste één ouder van Nederlandse afkomst hogere cijfers behalen, echter als er wordt gekeken naar de taal die thuis wordt gesproken zien we een negatieve significante relatie; studenten die geen Nederlands spreken thuis, halen hogere cijfers dan studenten die Nederlands spreken thuis. Motivatiekenmerken spelen geen significante rol met betrekking tot de scriptiecijfers. Enkele persoonlijkheidskenmerken hebben daarentegen wel significante relaties met de behaalde scriptiecijfers. Open en risico-prefererende studenten scoren lager op scriptiecijfers.

Figuur 32 toont de groei in het behaalde cijfer in het eerste jaar naar het cijfer dat de student heeft gehaald voor de scriptie. Hieruit zien we dat het verschil tussen reguliere studenten en honoursstudenten dat aan het einde van het eerste jaar vrij groot was, kleiner is als we kijken naar het scriptie cijfer aan het einde van het laatste bachelor jaar. De studenten zijn dichter naar elkaar toegegroeid gedurende de bacheloropleiding en gemiddeld halen zowel de reguliere studenten als de honoursstudenten hoge cijfers voor de scriptie.

FIGUUR 32 Groei in cijfer (scriptiecijfer versus gemiddeld cijfer in eerste jaar) voor reguliere studenten en honoursstudenten

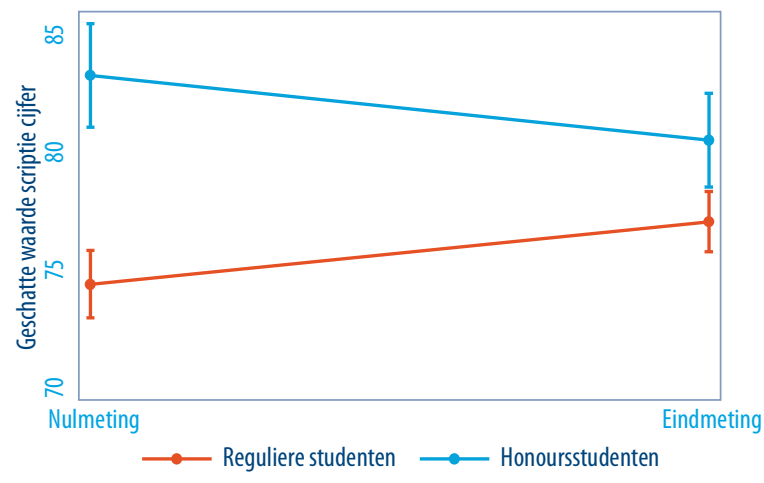


TABEL 26 Repeated measures-model voor scriptiecijfer

\begin{tabular}{|c|c|c|c|c|c|c|}
\hline & M1 & M2 & M3 & M4 & M5 & M6 \\
\hline Honoursstudenten (ref.=reguliere studenten) & $5.638^{* * *}$ & $8.689^{* * *}$ & $8.885^{* * *}$ & $7.620^{* * *}$ & $6.922^{* * *}$ & $7.599^{* * *}$ \\
\hline Eindmeting (ref.=nulmeting) & $1.358^{*}$ & $2.903^{* * *}$ & $2.824^{* * *}$ & $2.845^{* * *}$ & $2.281^{* *}$ & $2.805^{* * *}$ \\
\hline Honoursstudenten * eindmeting & & $-5.477^{* * *}$ & $-5.573^{* * *}$ & $-5.922^{* * *}$ & $-5.677^{* * *}$ & $-5.779^{* * *}$ \\
\hline Cohort 2018-19 (ref.=cohort 2017-18) & & & -0.919 & -0.451 & -0.268 & -0.500 \\
\hline Examencijfer middelbare school & & & & $0.339^{* * *}$ & $0.291^{* * *}$ & $0.327^{* * *}$ \\
\hline \multicolumn{7}{|l|}{ Achtergrondkenmerken van de student } \\
\hline \multicolumn{7}{|l|}{ Herkomst van de student (ref.=anders) } \\
\hline Tenminste een ouder van Nederlandse afkomst & & & & & $3.468^{* *}$ & \\
\hline \multicolumn{7}{|l|}{ Gesproken taal thuis (ref.=anders) } \\
\hline Nederlandse taal & & & & & $-5.013 * * *$ & \\
\hline \multicolumn{7}{|l|}{ Opleidingsniveau ouders (ref.=W0) } \\
\hline Basisonderwijs \& VMBO & & & & & $5.827^{*}$ & \\
\hline HAVO, VWO \& MBO & & & & & 0.997 & \\
\hline HBO & & & & & -1.369 & \\
\hline \multicolumn{7}{|l|}{ Inkomen ouders (ref.=modaal) } \\
\hline Beneden modaal & & & & & -0.031 & \\
\hline Boven modaal & & & & & 1.206 & \\
\hline \multicolumn{7}{|l|}{ Motivatiekenmerken van de student } \\
\hline Intrinsieke motivatie & & & & & & -0.828 \\
\hline Extrinsieke motivatie & & & & & & 0.697 \\
\hline Consistentie van inzet & & & & & & -0.801 \\
\hline Doorzettingsvermogen & & & & & & 1.163 \\
\hline \multicolumn{7}{|l|}{ Persoonlijkheidskenmerken van de student } \\
\hline Neuroticisme & & & & & & -0.503 \\
\hline Extraversie & & & & & & 0.286 \\
\hline Openheid & & & & & & $-0.971^{*}$ \\
\hline Inschikkelijkheid & & & & & & -0.449 \\
\hline Zorgvuldigheid & & & & & & 1.319 \\
\hline Zelf-effectiviteit & & & & & & 0.011 \\
\hline Risicopreferentie & & & & & & $-0.384^{*}$ \\
\hline Constant & $75.288^{* * *}$ & $74.382^{* * *}$ & $74.811^{* * *}$ & $46.653^{* * *}$ & $50.539^{* * *}$ & $49.697^{* * *}$ \\
\hline $\mathrm{N}$ & 451 & 451 & 451 & 449 & 391 & 449 \\
\hline
\end{tabular}

${ }^{*} p<0.1,{ }^{* *} p<0.05,{ }^{* * *} p<0.01$

\subsubsection{Cijfers gedurende bachelor jaar 1, 2 en 3}

In Figuur 33 worden de behaalde cijfers uitgesplitst naar leerjaar 1, 2 en 3 van de bacheloropleiding. In het eerste jaar zien we het grootste verschil tussen reguliere studenten en honoursstudenten. Reguliere studenten scoren gemiddeld een 7.44 en honoursstudenten gemiddeld een 8,31. Vervolgens zien we in het tweede en derde jaar dat de verschillen tussen reguliere studenten en honoursstudenten iets kleiner worden. In het tweede jaar halen reguliere studenten gemiddeld een 7.51 en in het derde leerjaar halen 
ze gemiddeld een 7.75. Voor honoursstudenten zien we dat het gemiddelde cijfer in het tweede jaar een 8.03 is en in het derde jaar een 7.81 is.

FIGUUR 33 Gemiddeld cijfer in bachelorjaar 1, 2 en 3 voor reguliere studenten en honoursstudenten

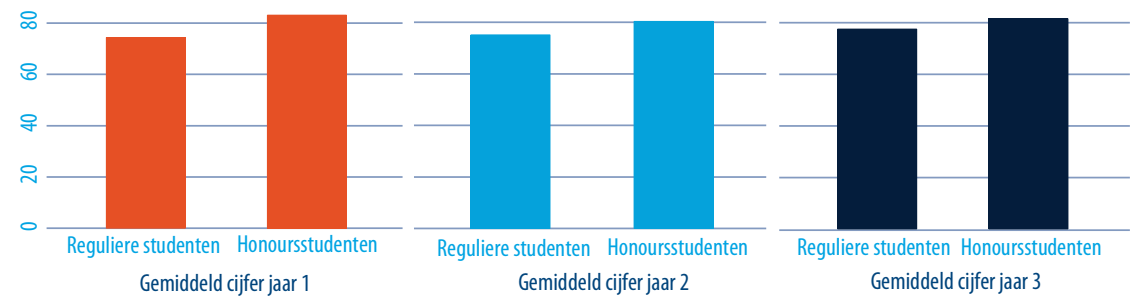

In Tabel 27 staan de uitkomsten van de multilevel repeated measures modellen voor de gemiddelde cijfers van de studenten. De cijfers van bachelor jaar 1, 2 en 3 worden met elkaar vergeleken en er wordt bekeken of na verloop van de jaren studenten steeds hogere cijfers gaan halen. Honoursstudenten halen vergeleken met reguliere studenten significant hogere cijfers. Wanneer we kijken naar de verschillen tussen de jaren, zien we dat voor alle studenten er geen significante relatie bestaat tussen bachelorjaar 1 en jaar 2, echter wanneer we kijken naar het verschil tussen jaar 1 en jaar 3 zien we dat studenten significant hogere cijfers behalen. De interactie-effecten laten voor zowel het tweede jaar en het derde jaar een negatieve coëfficiënt zien voor de honoursstudenten. Dit geeft aan dat vergeleken met het eerste studiejaar, honoursstudenten gedurende hun bachelor gemiddeld lagere cijfers halen. Zoals eerder besproken kan dit voor een deel verklaard worden door de relatief hoge toelatingseis en cijfer-restrictie. Desalniettemin blijven honoursstudenten hogere cijfers behalen dan reguliere studenten.

In het vierde model wordt de controle voor het gemiddeld examencijfer van de middelbare school toegevoegd, en de positieve significante relatie toont aan dat hogere cijfers op de middelbare school gerelateerd zijn aan hogere cijfers gedurende de universitaire bachelor. In het vijfde model worden de achtergrondkenmerken van de student toegevoegd. Studenten met een Nederlandse herkomst scoren significant hoger dan studenten met andere achtergronden. Wanneer in het laatste model wordt gekeken naar motivatiekenmerken en persoonlijkheidskenmerken, zien we dat er voor intrinsiek gemotiveerde studenten een negatieve significante relatie is met het gemiddeld behaalde cijfer en voor studenten met een hoger doorzettingsvermogen een positieve significante relatie. Qua persoonlijkheidskenmerken hebben extraverte en zorgvuldige studenten een significant positieve relatie met het behaalde cijfer, open en risico-prefererende studenten hebben een significant negatieve relatie met de behaalde cijfers.

In Figuur 34 wordt de groei in behaalde cijfers geschetst gedurende verschillende momenten, namelijk het gemiddeld cijfer van jaar 1; het gemiddelde cijfer van jaar 2 en gemiddelde cijfer van jaar 3. Hieruit blijkt dat honoursstudenten tijdens de eerste 
meting het hoogste cijfer halen, en gedurende de tweede en derde meting lager gaan scoren, maar nog steeds hoger dan reguliere studenten. Reguliere studenten daarentegen gaan steeds hogere cijfers halen naarmate de opleiding volgt. Het gemiddelde cijfer van het derde bachelor jaar is niet meer significant verschillend voor reguliere studenten en honoursstudenten.

FIGUUR 34 Groei in gemiddeld cijfer voor reguliere studenten en honoursstudenten

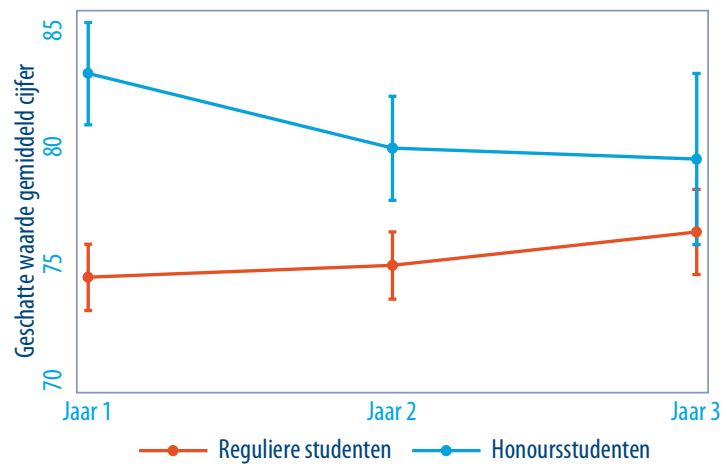

TABEL 27 Repeated measures-model voor het gemiddelde cijfer van jaar 1, 2 en 3

\begin{tabular}{|c|c|c|c|c|c|c|}
\hline & M1 & M2 & M3 & M4 & M5 & M6 \\
\hline Honoursstudenten (ref.=reguliere studenten) & $6.751^{* * *}$ & $8.669^{* * *}$ & $8.722^{* * *}$ & $7.125^{* * *}$ & $6.400^{* * *}$ & $7.403^{* * *}$ \\
\hline \multicolumn{7}{|l|}{ Meting (ref.=jaar 1) } \\
\hline Jaar 2 & -0.620 & 0.512 & 0.511 & 0.492 & 0.081 & 0.431 \\
\hline Jaar 3 & 0.819 & $1.958^{* * *}$ & $1.945^{* * *}$ & $1.888^{* *}$ & $2.185^{* * *}$ & $1.750^{* *}$ \\
\hline Honoursstudenten * jaar 2 meting & & $-3.707^{* * *}$ & $-3.707^{* * *}$ & $-3.659 * * *$ & $-3.146^{* * *}$ & $-3.557^{* * *}$ \\
\hline Honoursstudenten * jaar 3 meting & & $-5.606^{* * *}$ & $-5.611^{* * *}$ & $-5.437^{* * *}$ & $-6.191^{* * *}$ & $-5.391^{* * *}$ \\
\hline Cohort 2018-19 (ref.=cohort 2017-18) & & & -0.243 & 0.407 & 0.394 & 0.891 \\
\hline Examencijfer middelbare school & & & & $0.437^{* * *}$ & $0.417^{* * *}$ & $0.411^{* * *}$ \\
\hline \multicolumn{7}{|l|}{ Achtergrondkenmerken van de student } \\
\hline \multicolumn{7}{|l|}{ Herkomst van de student (ref.=anders) } \\
\hline \multicolumn{2}{|l|}{ Tenminste een ouder van Nederlandse afkomst } & & & & $3.427^{*}$ & \\
\hline \multicolumn{7}{|l|}{ Gesproken taal thuis (ref.=anders) } \\
\hline Nederlandse taal & & & & & -3.291 & \\
\hline \multicolumn{7}{|l|}{ Opleidingsniveau ouders (ref.=W0) } \\
\hline Basisonderwijs \& VMBO & & & & & -0.195 & \\
\hline HAVO, VWO \& MBO & & & & & 1.185 & \\
\hline $\mathrm{HBO}$ & & & & & -1.743 & \\
\hline \multicolumn{7}{|l|}{ Inkomen ouders (ref.=modaal) } \\
\hline Beneden modaal & & & & & 0.017 & \\
\hline Boven modaal & & & & & 0.178 & \\
\hline \multicolumn{7}{|l|}{ Motivatiekenmerken van de student } \\
\hline Intrinsieke motivatie & & & & & & $-2.582^{* *}$ \\
\hline
\end{tabular}


TABEL 27 Repeated measures-model voor het gemiddelde cijfer van jaar 1, 2 en 3

\begin{tabular}{|c|c|c|c|c|c|c|}
\hline & M1 & M2 & M3 & M4 & M5 & M6 \\
\hline Extrinsieke motivatie & & & & & & 0.598 \\
\hline Consistentie van inzet & & & & & & -1.077 \\
\hline Doorzettingsvermogen & & & & & & $2.406^{* *}$ \\
\hline \multicolumn{7}{|c|}{ Persoonlijkheidskenmerken van de student } \\
\hline Neuroticisme & & & & & & -0.807 \\
\hline Extraversie & & & & & & $1.109^{*}$ \\
\hline Openheid & & & & & & $-1.271^{* *}$ \\
\hline Inschikkelijkheid & & & & & & 0.484 \\
\hline Zorgvuldigheid & & & & & & $1.809^{*}$ \\
\hline Zelf-effectiviteit & & & & & & -1.357 \\
\hline Risicopreferentie & & & & & & $-0.570^{* *}$ \\
\hline Constant & $75.015^{* * *}$ & $74.431^{* * *}$ & $74.544^{* * *}$ & $38.184^{* * *}$ & $40.152^{* * *}$ & $45.560^{* * *}$ \\
\hline var(Constant individual) & $55.721^{* * *}$ & $56.659^{* * *}$ & $56.644^{* * *}$ & $43.131^{* * *}$ & $34.359^{* * *}$ & $35.895^{* * *}$ \\
\hline var(Residual) & $16.009^{* * *}$ & $14.533^{* * *}$ & $14.533^{* * *}$ & $14.674^{* * *}$ & $13.229^{* * *}$ & $14.702^{* * *}$ \\
\hline $\mathrm{N}$ & 427 & 427 & 427 & 424 & 355 & 424 \\
\hline
\end{tabular}

\subsection{Extra analyses}

Om de resultaten in dit hoofdstuk verder uit te werken en te controleren, zijn enkele extra analyses uitgevoerd om te bekijken of de hoofdresultaten veranderen. Het kan namelijk zo zijn dat bepaalde groepen studenten sterke negatieve of positieve uitkomsten hebben vergeleken met andere groepen studenten en dat voor bepaalde groepen studenten de conclusies die getrokken worden niet toepasbaar zijn of juist nog sterker naar voren zouden komen. De volgende extra analyses hebben plaatsgevonden; (i) 9-item Alternate Uses Tests, (ii) extra vergelijkingen met studenten die in aanmerking kwamen voor excellentieprogramma's als specifieke controlegroep, (iii) uitsplitsing naar hbo en wo studenten, (iv) kleinste sample per uitkomstmaat en (v) interactie-effecten voor bepaalde kwetsbare groepen studenten (vi) uitvalanalyse. Volledige resultaten van deze extra analyses zijn op aanvraag verkrijgbaar bij de auteurs.

In de eindmeting zijn drie extra items in de Alternate Uses Test opgenomen; deze zijn toegevoegd om herkenningseffecten te onderzoeken. Als studenten de nulmeting goed onthouden, kunnen ze gemakkelijker hoog scoren op de eindmeting. Om dit te onderzoeken zijn drie extra items toegevoegd, namelijk een afstandsbediening, föhn en paraplu. In de besproken resultaten in secties 4.3.1, 4.3.2 en 4.3.3 is uitgegaan van de zes items die zowel bij de nul- als eindmeting bevraagd zijn. In de extra analyse is bij de eindmeting gekeken naar een 9-item analyse. Voor de fluency-uitkomst - het aantal goede antwoorden, zien we geen afwijkingen in de hoofdresultaten die besproken zijn, voor de perseverance-uitkomst - het doorzettingsvermogen van de Alternate Uses Test, zien we ook geen afwijkingen in de hoofdresultaten. Voor de flexibility-uitkomst - het aantal originele categorieën waarbinnen de student correcte antwoorden geeft, zien we dat door de toevoeging van drie nieuwe items, het gemiddeld aantal nieuwe categorieën 
omlaag gaat. Echter, dit is zowel voor reguliere studenten als voor honoursstudenten het geval, waaruit geconcludeerd kan worden dat de hoofdresultaten hetzelfde blijven, namelijk dat de groei-indicator aangeeft dat reguliere studenten en honoursstudenten niet significant van elkaar verschillen in de groei op deze uitkomstmaat.

Omdat honoursstudenten een selecte groep studenten zijn, is er ook gekeken naar een groep studenten die een betere controlegroep zou kunnen zijn, namelijk studenten die in aanmerking zijn gekomen voor deelname aan excellentieprogramma's maar hier uiteindelijk toch niet aan begonnen zijn. In de extra analyses zijn de significante verschillen berekend tussen honoursstudenten en reguliere studenten zonder studenten die in aanmerking kwamen voor excellentieprogramma's, en honoursstudenten versus alle studenten die in aanmerking kwamen. Dit om een zuivere vergelijking te kunnen maken voor honoursstudenten versus reguliere studenten en honoursstudenten versus reguliere studenten die in aanmerking kwamen. Een algemene conclusie is dat studenten die in aanmerking kwamen voor excellentieprogramma's ongeveer tussen reguliere studenten en honoursstudenten invallen. Ze scoren vaak 'beter' dan reguliere studenten, maar groeien minder sterk, en eindigen op de eindmeting vaak gelijk aan reguliere studenten. De studieresultaten van deze groep bevestigen dit, ze scoren het eerste jaar hoge cijfers, aangezien het essentieel is om in aanmerking te komen voor excellentieprogramma's en ervaren daarna een gelijke negatieve groei in hun gemiddelde cijfer, maar scoren gemiddeld nog steeds hoger dan de reguliere studenten. Het uitsplitsen van de groep reguliere studenten toont aan dat (a) de gevonden niet-significante verschillen in groei tussen reguliere studenten en honoursstudenten niet veranderen en (b) er zijn geen significante verschillen tussen honoursstudenten en reguliere studenten die in aanmerking kwamen voor een excellentieprogramma zijn.

Excellentieprogramma's in het hoger onderwijs en op universiteiten zijn ook apart geanalyseerd. Dezelfde modellen als besproken in deze sectie zijn opnieuw gedraaid voor alleen hbo studenten en wo studenten. De resultaten tonen aan dat er nauwelijks afwijkingen zijn als de modellen worden gesplitst naar het niveau in het hoger onderwijs.

Daarnaast verschilt het aantal studenten soms tussen onze modellen. Dit komt omdat sommige studenten de achtergrondgegevens niet wilden invullen (met name gegevens over de ouders). Daarom hebben we alle modellen nog eens opnieuw geschat, maar nu alleen voor studenten voor wie we geldige informatie hebben voor alle variabelen in onze modellen. Hieruit komen geen afwijkende resultaten wat betreft de hoofdresultaten.

Enkele interactie-effecten zijn daarnaast in de analysemodellen toegevoegd om te bekijken of we voor bepaalde groepen studenten andere relaties vinden tussen deelname aan honoursprogramma's en de uitkomstmaten, en daardoor minder groeien gedurende hun bachelorperiode. De groepen die we hiermee willen analyseren zijn met name studenten uit kwetsbare groepen, zoals studenten met laagopgeleide ouders, ouders met lage inkomens en studenten van buitenlandse afkomst. Er is gekeken naar de migratiestatus van de ouders en de gesproken taal thuis, het opleidingsniveau van de 
ouders, het inkomen van de ouders. De conclusie is dat de hoofdresultaten niet veranderen hierdoor en er geen systematisch afwijking is voor bepaalde groepen studenten. De groei die studenten doormaken gedurende hun opleiding verschilt niet voor deze verschillende groepen studenten.

Als laatste heeft er een uitvalanalyse plaatsgevonden om te controleren of er systematische verschillen zijn tussen studenten die wel en niet uitgevallen zijn uit dit onderzoek tussen de nulmeting en eindmeting. Dit bleek niet het geval te zijn, op een enkele uitzondering na: de gemiddelde scores voor de creativiteitstest Alternate Uses Test lagen significant lager voor studenten die uitgevallen zijn tussen de nulmeting en de eindmeting. Voor studenten die zowel de nulmeting als de eindmeting hebben ingevuld ligt de score op de eindmeting enerzijds mogelijk hoger door herkenning van de test, aangezien de studenten deze test in de nulmeting ook hebben voltooid. Het verschil kan echter ook te verklaren zijn doordat studenten die deze test moeilijk of niet leuk vonden niet wilden deelnemen aan de eindmeting van deze vragenlijst omdat ze dan nogmaals de Alternate Uses Test zouden moeten voltooien. 


\section{CONCLUSIE EN DISCUSSIE}

\section{$5.1 \quad$ Inleiding}

In dit hoofdstuk zetten we de belangrijkste conclusies van dit onderzoek op een rij. We beginnen met een bespreking van de conclusies van de twee deelprojecten, en geven antwoord op de hoofdvragen die we voor de beide deelprojecten geformuleerd hebben in hoofdstuk 1. Vervolgens gaan we in op een aantal beperkingen van dit onderzoek, en op de implicaties van deze beperkingen voor onze conclusies en voor vervolgonderzoek. We eindigen dit hoofdstuk met aanbevelingen voor verder onderzoek en voor beleid.

\subsection{Belangrijkste conclusies}

\subsubsection{Deelproject 1: selectie van studenten}

Deelproject 1 brengt zo breed mogelijk de selectie van studenten voor excellentieprogramma's in kaart. De hoofdvraag die hierbij beantwoord wordt, luidt als volgt: hoe kan de selectie van kandidaten voor excellentieprogramma's verbeterd worden en welke instrumenten geven de beste match tussen persoon en programma? Daarbij gaat het zowel om het in kaart brengen van het selectieproces en de instrumenten die daarbij gebruikt worden, als om het toetsen van factoren die het succesvol afronden van excellentieprogramma's kunnen voorspellen.

De resultaten hebben duidelijker in beeld gebracht dat de studenten die deelnamen aan excellentieprogramma's al bij de start van het programma hoger scoorden op de meeste cognitieve en non-cognitieve uitkomstmaten dan studenten in het regulier onderwijs. Wanneer er wordt gekeken naar de kans om deel te nemen aan excellentieprogramma's laten de resultaten zien dat kritisch denkvermogen en studieresultaten belangrijke factoren zijn om de deelname te voorspellen. Daarnaast is de kans op deelname aan excellentieprogramma's hoger voor studenten die meer intrinsiek en extrinsiek gemotiveerd en zorgvuldiger zijn. Vervolgens is onderzocht welke instrumenten en vaardigheden het succesvol afronden van excellentieprogramma's kunnen verklaren. De resultaten tonen aan dat geen van de relevant geachte factoren een duidelijk effect hebben op de kans op succesvolle afronding van excellentieprogramma's. Uit de resultaten van deze analyses komt wel naar voren dat honoursstudenten die meer uren per 
week werken naast hun studie een kleinere kans hebben op succesvolle afronding van het excellentieprogramma.

In de vignettenanalyse die afgenomen is onder selecteurs van excellentieprogramma's komt sterk naar voren dat selecteurs gedurende het selectieproces de 'beste' studenten willen aannemen. Voor zowel hbo als wo geldt dat hogere cijfers en meer extracurriculaire ervaringen zoals buitenlandervaring, studie-gerelateerde bijbaan en vrijwilligerswerk positief bijdragen aan de kans om aangenomen te worden voor excellentieprogramma's. Daarnaast spelen motivatie, denkvermogen, doorzettingsvermogen, maatschappelijke betrokkenheid en creativiteit een belangrijke rol in het aannemen van studenten. De selecteurs geven aan dat deze kenmerken van een student, mits een student behoort tot de top $25 \%$ op deze vijf kenmerken, de vijf belangrijkste kenmerken zijn voor het aannemen van de student.

\subsubsection{Deelproject 2: effecten van excellentieprogramma's}

Deelproject 2 richt zich op de effecten van deelname aan excellentieprogramma's op cognitieve en non-cognitieve uitkomstmaten, om vast te stellen of excellentieprogramma's toegevoegde waarde hebben voor de cognitieve en non-cognitieve ontwikkeling van studenten. Een van de problemen bij het vaststellen van de toegevoegde waarde van excellentieprogramma's is dat de geselecteerde studenten al voordat ze aan hun excellentieprogramma beginnen een bijzondere, selectieve groep zijn. In een kwantitatieve analyse is daarom bekeken of studenten die deelnamen aan excellentieprogramma's een sterkere groei hebben doorgemaakt dan studenten die niet hieraan deelnamen, rekening houdend met verschillen in de beginsituatie. De hoofdvraag die in deelproject 2 beantwoord wordt is als volgt: wat is de individuele toevoegende waarde van deelname aan excellentieprogramma's voor studenten voor zowel cognitieve als non-cognitieve vaardigheden?

De belangrijkste conclusie die getrokken kan worden uit deelproject 2 is dat honoursstudenten die gedurende hun bachelor hebben deelgenomen aan excellentieprogramma's zich zowel op cognitieve en non-cognitieve uitkomstmaten positief hebben ontwikkeld. Echter, reguliere studenten maken een soortgelijke positieve groei door. Honoursstudenten verschillen daarin niet wezenlijk van studenten in het regulier onderwijs. Dit betekent overigens niet noodzakelijkerwijs dat honoursstudenten nadeel ondervinden van deelname aan excellentieprogramma's. Zo lijkt deelname aan excellentieprogramma's niet ten koste te gaan van bijvoorbeeld studieresultaten: honoursstudenten blijven gedurende hun gehele bachelorprogramma hogere studieresultaten behalen dan reguliere studenten. Over het algemeen halen honoursstudenten hogere scores op alle uitkomstmaten, waarbij de voornaamste verklaring is dat honoursstudenten al bij de start van de excellentieprogramma's beter op de meeste cognitieve en non-cognitieve uitkomstmaten scoorden dan studenten in het regulier onderwijs. Dit suggereert dat de belangrijkste verschillen tussen beide groepen voortkomen uit selectie van studenten voor excellentieprogramma's. Wij vinden geen aanwijzingen voor leeruitkomsten op het gebied van kritisch denken, creativiteit, leiderschap, of andere 
uitkomstmaten die specifiek toe te wijzen zijn aan deelname aan excellentieprogramma's.

Tot slot is het belangrijk om op te merken dat onze belangrijkste conclusies zowel voor cognitieve als voor non-cognitieve uitkomstmaten opgaan. Hoewel wij in dit onderzoek verder zijn gegaan dan bestaand onderzoek door naar meer diverse uitkomstmaten te kijken heeft dit onze conclusies niet beïnvloed. Aan de andere kant betekent dit ook dat onze belangrijkste conclusies breed ondersteund worden. Ook het gebruik van zowel objectieve testen als subjectieve metingen van kritisch denken en creativiteit is van toegevoegde waarde geweest: onze resultaten laten zien dat de relatie tussen objectieve en subjectieve meting vaak zwak is, en dat studenten hun capaciteiten en ontwikkeling op deze punten lijken te onderschatten. Al met al kunnen we stellen dat het gebruik van zowel cognitieve als non-cognitieve uitkomstmaten vooral de robuustheid van onze conclusies onderstreept, en verder een aantal interessante vragen en bevindingen voortbrengt voor een breder publiek van onderzoekers en beleidsmakers die zich bezighouden met objectieve en subjectieve metingen van vaardigheden.

\subsection{Beperkingen van dit onderzoek}

In dit onderzoek zijn we ook op enkele beperkingen gestuit die we willen benoemen om de context waarin dit onderzoek heeft plaatsgevonden verder te duiden, en om voor vervolgonderzoek aan te geven waar op dit moment de voornaamste praktische uitdagingen lijken te liggen. Om te beginnen hebben we (zoals gebruikelijk bij longitudinaal onderzoek) te maken met uitval van respondenten tussen de nulmeting en de eindmeting. Een uitvalanalyse liet echter zien dat het niet waarschijnlijk is dat selectieve uitval onze belangrijkste conclusies beïnvloed heeft. Verder heeft ons gebruik van repeated measures-modellen in onze analyses ons de kans gegeven om de informatie van studenten die alleen aan de nulmeting hebben deelgenomen alsnog te kunnen gebruiken in dit onderzoek.

Ten tweede was aanvankelijk het idee om informatie over de studenten deels te verkrijgen via de studentadministraties, om de vragenlijst voor de studenten zo kort mogelijk te houden, en om een zo volledig mogelijk beeld te krijgen van de behaalde studieresultaten. Het verkrijgen van gegevens van de studentenadministraties bleek na de invoering van de Algemene Verordening Gegevensbescherming (AVG) echter problematisch te zijn voor meerdere instellingen, en uiteindelijk hebben we in onze analyses slechts gebruik kunnen maken van studentadministratiedata voor één instelling. Om toch informatie over studieresultaten van de studenten te verkrijgen, zijn er in de eindmeting extra vragen over studievoortgang opgenomen in de vragenlijst. Al met al hebben we hierdoor uiteindelijk in beide deelprojecten alsnog naar de rol van studieresultaten kunnen kijken, al berusten onze gegevens nu deels op zelfgerapporteerde cijfers. Anderzijds is een belangrijke boodschap voor toekomstige onderzoeken die gebruik willen maken van studentenadministratiedata dat de bereidheid om deze 
gegevens te delen voor onderzoek sinds de invoering van de AVG beperkter lijkt te zijn geworden.

Ten derde leek het in theorie interessant om voor de analyse van individuele effecten van excellentieprogramma's gebruik te maken van een zogenaamd regression discontinuity design, maar dit bleek praktisch onmogelijk te zijn gegeven de diversiteit in de selectieprocedures voor excellentieprogramma's. Met een regression discontinuity design kan worden bekeken of studenten die net wel of net niet de cijfereis halen voor toelating tot excellentieprogramma's een significant verschil kenden in hun ontwikkeling tijdens hun bachelorperiode. Door hierbij te focussen op studenten die vrijwel dezelfde cijfers haalden in het eerste jaar van hun bacheloropleiding zou eventueel nog scherper rekening gehouden kunnen worden met de mogelijke rol van selectie-effecten in het bekijken van de toegevoegde waarde van excellentieprogramma's. In de context van excellentieprogramma's in Nederland bleek dit echter niet de juiste aanpak om het effect van excellentieprogramma's te schatten. Ten eerste is er bij de selectie van meerdere excellentieprogramma's geen 'harde' eis, zoals bijvoorbeeld minimaal een 8 behaald tijdens het eerste jaar. Vaak zijn er zachtere regels, zoals het (bijna) zonder vertraging halen van het eerste studiejaar. Ook zijn er bij sommige excellentieprogramma's dusdanige problemen met het toelaten van genoeg studenten, dat er soms studenten worden toegelaten die initieel niet aan de selectiecriteria voldeden. Een harde toelatingseis is essentieel om een regression discontinuity design toe te passen. Ten tweede zouden, vanwege de relatief kleine sample, de data gepoold moeten worden (dat wil zeggen, we hadden studenten van alle instellingen samen tegelijk moeten analyseren om de statistische power van de analyse te vergroten). Dit brengt echter het probleem met zich mee dat alle excellentieprogramma's verschillende selectiecriteria hebben en deze niet onder een algemene harde grens samen te brengen zijn. Al met al bleek dit project dan ook niet geschikt voor het gebruik van een regression discontinuity design. In vervolgonderzoek naar effecten van excellentieprogramma's kan dit eventueel alsnog een interessante optie zijn, mits dit onderzoek zich richt op een beperkt aantal instellingen met een identieke en 'harde' cijfereis, en mits de sample voor elk van deze instellingen groter is dan de samples in dit project.

\subsection{Aanbevelingen}

\subsubsection{Aanbevelingen voor verder onderzoek}

Hoewel dit onderzoek duidelijk in beeld heeft gebracht welke factoren een rol spelen bij de keuzes die selecteurs maken, hebben wij in dit deelonderzoek geen aandacht besteed aan het keuzeproces van de studenten. Welke factoren spelen een rol bij de keuzes die studenten maken, en wat zien studenten als de meerwaarde van deelname aan excellentieprogramma's? Het belang van deze vragen wordt onderstreept door onze bevinding dat motivatie (zowel intrinsiek als extrinsiek) een belangrijke rol speelt in het selectieproces, waarbij het moeilijk te onderscheiden valt of wat we hier meten vooral gedreven wordt door selectie (selecteurs kiezen studenten die laten zien dat ze gemotiveerd zijn), of ook door zelfselectie (vooral de meest -extrinsiek- gemotiveerde 
studenten solliciteren naar deelname in excellentieprogramma's). Verder onderzoek zou gezien het gebleken belang van motivatie dieper kunnen ingaan op verschillende soorten en indicatoren van motivatie.

Ook onze resultaten met betrekking tot de individuele effecten van deelname aan excellentieprogramma's bevestigen dat meer aandacht voor het perspectief van de student interessant zou zijn. Zo roept onze bevinding dat studenten in excellentieprogramma's een groei doormaken in de gekozen uitkomstmaten die gelijk is aan die van reguliere studenten enkele vragen op: kijken we wel naar de meest relevante uitkomstmaten om de ontwikkeling van studenten vast te stellen? En zouden we ook meer moeten (en kunnen) kijken naar verwachtingen die studenten zelf wellicht hadden van hun deelname aan excellentieprogramma's, en in hoeverre aan deze verwachtingen voldaan is (bijv. meer uitdaging, verbreding, en verdieping)? Om de implicaties van onze bevindingen voor alle betrokken doelgroepen helder te krijgen zou het goed zijn om meer te weten over in hoeverre studenten zich bij de keuze voor deelname aan excellentieprogramma's laten leiden door de wens om bepaalde cognitieve en non-cognitieve skills te verbeteren. In het deelonderzoek rond uitstralingseffecten van excellentieonderwijs is het studentperspectief wel aan bod gekomen (zie het afzonderlijke eindrapport 'Uitstralingseffecten van excellentieonderwijs; van innovatie naar uitstraling').

Een tweede punt voor vervolgonderzoek dat hieraan gerelateerd is heeft betrekking op studenten die uitvallen uit het excellentieprogramma's. Een tweede punt voor vervolgonderzoek dat hieraan gerelateerd is heeft betrekking op studenten die het excellentieprogramma voortijdig verlaten. Helaas is het binnen ons onderzoek niet mogelijk geweest om meer informatie te verkrijgen over de beweegredenen van studenten die een excellentieprogramma voortijdig verlaten hebben. Hierbij zou het interessant zijn om een onderscheid te kunnen maken tussen verschillende beweegredenen, en tussen redenen die wel en geen betrekking hebben op het excellentieprogramma zelf. Hoewel ons onderzoek goed in beeld gebracht heeft hoe studenten geselecteerd worden voor excellentieprogramma's, en welke rol selecteurs hierin spelen, is op dit moment nog minder duidelijk hoe we het voortijdig verlaten van excellentieprogramma's kunnen beperken. Voor zowel studenten als voor hogeronderwijsinstellingen is het van belang om studenten zo selecteren dat ze het excellentieprogramma ook afmaken. Met andere woorden, het gaat er niet slechts om dat alleen de studenten met de juiste motivatie en cognitieve eigenschappen gekozen worden, maar ook dat deze studenten vervolgens blijven, en het programma succesvol afronden. In ons onderzoek hebben we wel bekeken welke factoren bijdragen aan het afronden van excellentieprogramma's, maar helaas kwamen hierbij geen specifieke instrumenten naar voren die het succesvol afronden van de programma's goed kunnen voorspellen. Een analyse die zich meer richt op het verklaren van (redenen voor) voortijdig verlaten van het programma zou nieuw licht kunnen werpen op deze vragen, waarbij het toevoegen van een studentperspectief opnieuw van meerwaarde zou kunnen zijn. 


\subsubsection{Aanbevelingen voor beleidsmakers en beleidsuitvoerders}

Bij de selectie van studenten voor een excellentieprogramma, is de wens van zowel programma als student natuurlijk dat deze laatste het traject ook succesvol afrondt. Daarom wordt veel tijd en aandacht besteed aan de keuze van de juiste studenten. Uit dit onderzoek blijkt dat naar vele kenmerken wordt gekeken bij het selecteren van honoursstudenten. Helaas komen hierbij geen specifieke instrumenten naar voren die het succesvol afronden van de programma's goed kunnen voorspellen. Wel is gebleken dat een hoge extrinsieke motivatie een onderscheidende factor is. Voor deze studenten lijkt een excellentieprogramma een manier om zich (nog meer) naar de buitenwereld te kunnen onderscheiden van hun medestudenten. Ook laten de resultaten zien dat honoursstudenten wél al bij de start van de excellentieprogramma's hoog en meestal beter scoren op de uitkomstmaten dan studenten in het regulier onderwijs. Dit lijkt erop te duiden dat selecteurs er wel in slagen de uitblinkers te selecteren voor excellentieprogramma's. De invloed van het inkomens- en opleidingsniveau van ouders geeft echter wel enige aanleiding tot reflectie op de selectie van honoursstudenten en de toegankelijkheid van excellentieprogramma's voor studenten met verschillende achtergronden.

Tevens blijkt uit dit onderzoek dat honoursstudenten zich positief ontwikkelen op zowel cognitief als non-cognitief gebied tijdens het volgen van een excellentieprogramma. Dit is een mooie uitkomst, maar omdat de resultaten ook laten zien dat reguliere studenten een soortgelijke groei doormaken, zou men kunnen concluderen dat het volgen van een excellentieprogramma overbodig is. Dit zou te kort door de bocht zijn; veel excellentietrajecten hebben namelijk niet het (enkele) doel om bepaalde cognitieve en noncognitieve vaardigheden van honoursstudenten te verbeteren, maar ook om bijvoorbeeld het verbreden of verdiepen van kennis. Belangrijk is om gezamenlijk - docenten, coördinatoren, selecteurs, studenten - te kijken en scherp te krijgen wat de leerdoelen zijn binnen het aangeboden programma. Waar willen we de groei zien, wat zijn de verwachtingen, wat willen studenten eruit halen? Excellentietrajecten zijn bij uitstek geschikt om een leertraject op maat te bieden: elke student ontwikkelt zich op andere domeinen, dus leeruitkomsten en -opbrengsten zullen ook per persoon verschillend zijn. Dit past ook bij de doelstelling van talentontwikkeling die een van de kernelementen van excellentieonderwijs vormt: de onderwijsinstelling biedt onderwijs waarin alle studenten optimaal kunnen presteren, onafhankelijk van de vraag hoe talentvol zij zijn. De focus op talentontwikkeling is de afgelopen jaren ook tot uitdrukking gekomen in de verschuiving van het spreken over 'excellentie' naar 'talent'. Bhatt (2012) definieert het extra onderwijs van excellentieprogramma's als het ontwikkelen van een nieuw onderwijscurriculum dat beter aansluit op de behoeften van de groep studenten om zo de uitkomsten te bevorderen. Op deze manier is het mogelijk dat de groei die studenten in excellentieprogramma's hebben doorgemaakt alsnog deels te danken is aan het volgen van deze programma's, en aan de 'match' tussen specifieke studenten en programma's. In toekomstige onderzoeks- en beleidsprogramma's kan hier verder op ingezet worden door bijvoorbeeld effectiviteitsmetingen op het gebied van metacognitie en interdisciplinaire samenwerking, of door meer didactisch gerichte studies op te zetten naar de vormgeving van de activiteiten in excellentieprogramma's. 


\section{LITERATUUR}

Allen, J., Belfi, B., Velden, R., Jongbloed, B., Kolster, R., Westerheijden, D. F., Van Broekhoven, K., Leest, B., \& Wolbers, M. (2015). 'Het beste uit studenten'; Onderzoek naar de werking van het Sirius Programma om excellentie in het hoger onderwijs te bevorderen. Nijmegen: ITS, Radboud Universiteit Nijmegen.

Bui, S. A., Craig, S. G., \& Imberman, S. A. (2014). Is gifted education a bright idea? Assessing the impact of gifted and talented programs on students. American Economic Journal: Economic Policy, 6(3), 30-62.

Carson, S. H., Peterson, J. B., \& Higgins, D. M. (2005). Reliability, validity, and factor structure of the creative achievement questionnaire. Creativity Research Journal, 17(1), 37-50.

Coppoolse, R., van Dijk, T., Ter Woord, R., Weerheijm, R., Vroegindeweij, D., Van Eijl, P., \& Pilot, A. (2013). Excellentieprofielen in het hoger beroepsonderwijs. In Coppoolse, R., Van Eijl, P. \& Pilot, A. (eds). Hoogvliegers: ontwikkeling naar professionele excellentie (pp. 57-72). Rotterdam: Rotterdam University Press.

Credé, M., Harms, P., Niehorster, S., \& Gaye-Valentine, A. (2012). An evaluation of the consequences of using short measures of the Big Five personality traits. Journal of personality and social psychology, 102(4), 874

Dohmen, T., Falk, A., Huffman, D., Sunde, U., Schupp, J., \& Wagner, G. G. (2011). Individual risk attitudes: Measurement, determinants, and behavioral consequences. Journal of the European Economic Association, 9(3), 522-550.

Duckworth, A. L., Peterson, C., Matthews, M. D., \& Kelly, D. R. (2007). Grit: perseverance and passion for long-term goals. Journal of personality and social psychology, 92(6), 1087.

Furnham, A., Chamorro-Premuzic, T., \& McDougall, F. (2003). Personality, cognitive ability, and beliefs about intelligence as predictors of academic performance. Learning and individual Differences, 14(1), 47-64.

Ghanizadeh, A. (2017). The interplay between reflective thinking, critical thinking, self-monitoring, and academic achievement in higher education. Higher Education, 74(1), 101-114.

Goldberg, L. R. (1993). The structure of phenotypic personality traits. American psychologist, 48(1), 26.

Goldberg, L. R., Johnson, J. A., Eber, H. W., Hogan, R., Ashton, M. C., Cloninger, C. R., \& Gough, H. C. (2006). The International Personality Item Pool and the future of public-domain personality measures. Journal of Research in Personality, 40, 84-96.

Guilford, J. P. (1967). The nature of human intelligence. McGraw-Hill, New York (1967).

Heijltjes, A.E.G. (2014, January 30). Cultivating critical thinking: The effects of instructions on economics students' reasoning. Erasmus University Rotterdam. Retrieved from http://hdl.handle. net $/ 1765 / 50418$ 
Hernández-Torrano, D., \& Saranli, A. G. (2015). A cross-cultural perspective about the implementation and adaptation process of the schoolwide enrichment model: The importance of talent development in a global world. Gifted Education International, 31(3), 257-270.

Humphrey, T. (2008). Chapter 1: The Genesis of an Idea. In Sederberg, P.C. (eds), "The Honors College Phenomenon" (2008). NCHC Monographs Series. Paper 4.

Kolster, R., van Dijk, L., \& Jongbloed, B. W. (2016). Introducing Excellence in Higher Education. Honours Programmes in the Netherlands and Students' Preferences. Journal of the European Higher Education Area, 2016(3), 1-22.

Kool, A., Mainhard, T., Jaarsma, D., van Beukelen, P., \& Brekelmans, M. (2017). Effects of honours programme participation in higher education: a propensity score matching approach. Higher Education Research \& Development, 36(6), 1222-1236.

McManus, I. C., \& Furnham, A. (2006). Aesthetic activities and aesthetic attitudes: Influences of education, background and personality on interest and involvement in the arts. British Journal of Psychology, 97(4), 555-587.

Midgley, C., Maehr, M. L., Hruda, L. Z., Anderman, E., Anderman, L., Freeman, K. E., \& Urdan, T. (2000). Manual for the patterns of adaptive learning scales. Ann Arbor, 1001, 48109-1259.

Pintrich, P. R., Garcia, T., McKeachie, W. J., \& Smith, D. A. (1991). Motivated strategies for learning questionnaire. Regents of the University of Michigan.

Reiter-Palmon, R., Forthmann, B., \& Barbot, B. (2019). Scoring divergent thinking tests: A review and systematic framework. Psychology of Aesthetics, Creativity, and the Arts, 13(2), 144.

Renzulli, J. S. (1978). What Makes Giftedness? Reexamining a Definition. Phi Delta Kappan, 60, 180-184.

Renzulli, J. S. (2002). Emerging conceptions of giftedness: Building a bridge to the new century. Exceptionality, 10(2), 67-75.

Scager, K., Akkerman, S. F., Keesen, F., Tim Mainhard, M., Pilot, A., \& Wubbels, T. (2012). Do honors students have more potential for excellence in their professional lives? Higher Education, 64(1), 19-39.

Seligman, M. E., Park, N., \& Peterson, C. (2004). The Values In Action (VIA) classification of character strengths. Ricerche di Psicologia.

SLO (2019, 7 november), Curriculum van de toekomst. Kritisch denken. Geraadpleegd van http:// curriculumvandetoekomst.slo.nl/21e-eeuwse-vaardigheden/kritisch-denken.

Sudman, S., and Ferber, R. (1979). Consumer Panels. Chicago, II: American Marketing Association.

Van Eijl, P., Wolfensberger, M., Schreve-Brinkman, L., \& Pilot, A. (2007). Honours, tool for promoting excellence: Eindrapport van het project 'Talentontwikkeling in Honoursprogramma's en de meerwaarde die dat oplevert'. Utrecht: Interfacultair Instituut voor Lerarenopleiding, Onderwijsontwikkeling en Studievaardigheden Universiteit Utrecht i.s.m. het Landelijke Plusnetwerk voor Academische Honoursprogramma's.

Watson, G.B., \& Glaser, E. M. (2010). Watson-Glaser Il Critical Thinking Appraisal Technical Manual and User's Guide. London: The Psychological Corporation.

Wolfensberger, Marca V.C.; van Eijl, Pierre J.; and Pilot, Albert, "Honours Programmes as Laboratories of Innovation: A Perspective from the Netherlands" (2004). Journal of the National Collegiate Honors Council--Online Archive. 141.

Wolfensberger, M. V. (2015). Talent development in European higher education. Cham: Springer International Publishing. doi, 10, 978-3. 


\section{BIJLAGEN}

\section{Bijlagenoverzicht}

1. Overzicht van de timing van vragenlijstafname

2. Beschrijvende statistieken achtergrondvragenlijst

3. Beschrijvende statistieken studentenadministratie

4. Beschrijvende statistieken selecteursoordeel en afronding excellentieprogramma's

5. Beschrijvende statistieken vignetten onderzoek

6. De procedures en criteria voor selectie in het kort 


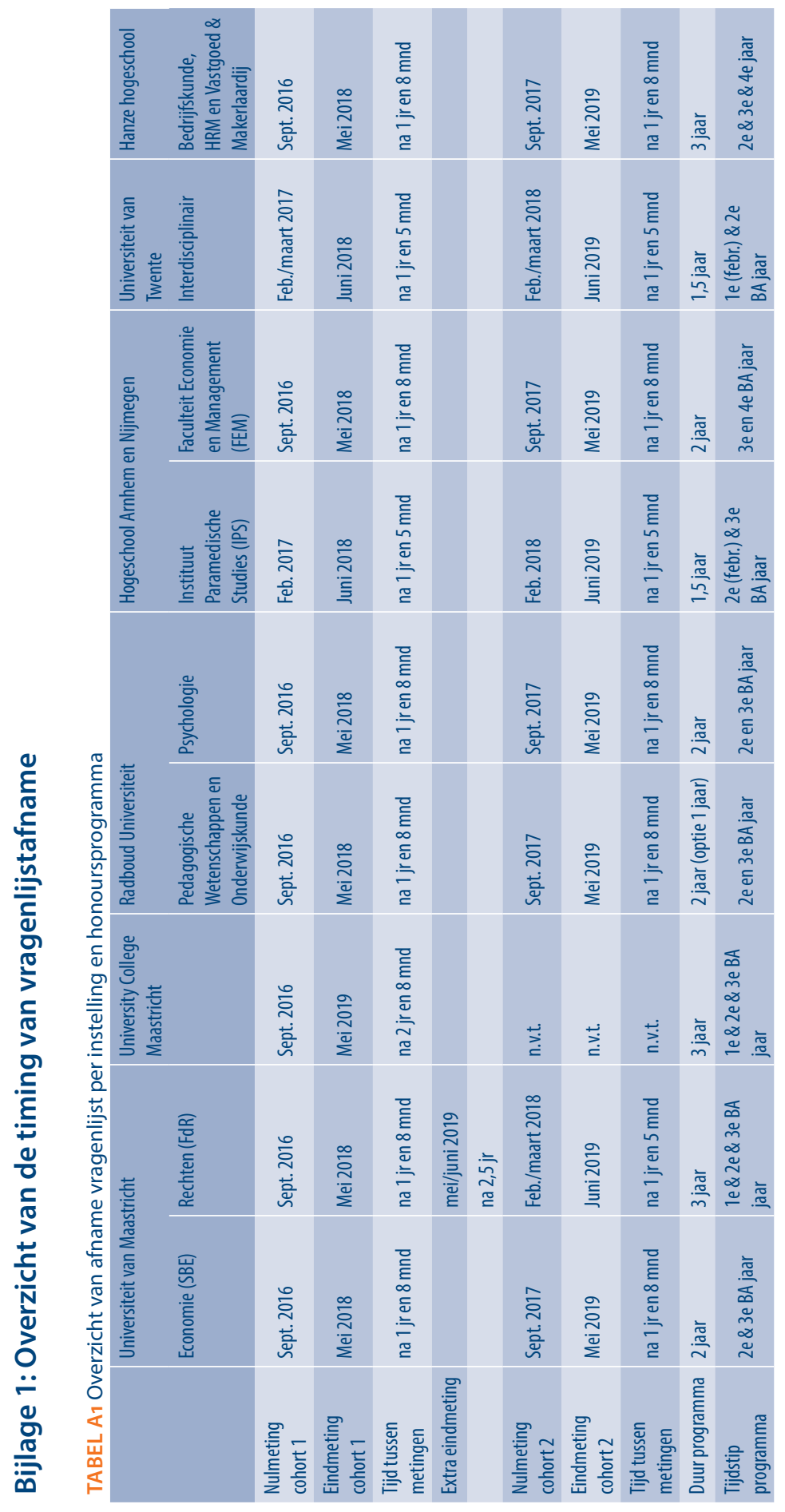




\section{Bijlage 2: Beschrijvende statistieken achtergrondvragenlijst}

TABEL A2.1 Descriptives belangrijkste variabelen nulmeting 1

\begin{tabular}{|c|c|c|c|c|c|}
\hline & $\mathrm{N}$ & mean & $s d$ & $\min$ & $\max$ \\
\hline \multicolumn{6}{|l|}{ Instelling } \\
\hline Maastricht Universiteit & 729 & 0,303155 & 0,459937 & 0 & 1 \\
\hline Hanze hogeschool & 729 & 0,046639 & 0,21101 & 0 & 1 \\
\hline Universiteit Twente & 729 & 0,170096 & 0,375975 & 0 & 1 \\
\hline Radboud Universiteit & 729 & 0,083676 & 0,277092 & 0 & 1 \\
\hline HAN hogeschool & 729 & 0,179698 & 0,384199 & 0 & 1 \\
\hline UCM & 729 & 0,216735 & 0,412304 & 0 & 1 \\
\hline Deelname aan excellentieprogramma & 571 & 0,383538 & 0,486674 & 0 & 1 \\
\hline In aanmerking excellentieprogramma & 343 & 2,154519 & 0,839121 & 1 & 3 \\
\hline Examencijfer middelbare school & 716 & 6,919972 & 2,066782 & 1 & 10 \\
\hline \multicolumn{6}{|l|}{ Migratieachtergrond } \\
\hline Geen ouders uit Nederland & 557 & 0,452424 & 0,498179 & 0 & 1 \\
\hline Tenminste één ouder uit Nederland & 557 & 0,547576 & 0,498179 & 0 & 1 \\
\hline \multicolumn{6}{|l|}{ Ouderlijk inkomen } \\
\hline Beneden modaal & 495 & 0,080808 & 0,272816 & 0 & 1 \\
\hline Modaal & 495 & 0,381818 & 0,486324 & 0 & 1 \\
\hline Boven modaal & 495 & 0,537374 & 0,499106 & 0 & 1 \\
\hline \multicolumn{6}{|l|}{ Hoogste opleiding ouders } \\
\hline Basisonderwijs & 702 & 0,007123 & 0,084154 & 0 & 1 \\
\hline LBO, VMBO, MAVO & 702 & 0,035613 & 0,185454 & 0 & 1 \\
\hline HAVO, VWO & 702 & 0,04416 & 0,205596 & 0 & 1 \\
\hline MBO & 702 & 0,108262 & 0,310933 & 0 & 1 \\
\hline $\mathrm{HBO}$ & 702 & 0,216524 & 0,412169 & 0 & 1 \\
\hline wo & 702 & 0,588319 & 0,492489 & 0 & 1 \\
\hline \multicolumn{6}{|l|}{ Gesproken taal thuis } \\
\hline Niet Nederlands sprekend & 558 & 0,480287 & 0,50006 & 0 & 1 \\
\hline Nederlands sprekend & 558 & 0,519713 & 0,50006 & 0 & 1 \\
\hline \multicolumn{6}{|l|}{ Motivatiekenmerken } \\
\hline Intrinsieke motivatie & 566 & 3,8803 & 0,558447 & 1,75 & 5 \\
\hline Extrinsieke motivatie & 566 & 3,506625 & 0,755555 & 1 & 5 \\
\hline Consistentie van interesse & 724 & 3,076013 & 0,677342 & 1 & 4,833333 \\
\hline Doorzettingsvermogen & 724 & 3,772422 & 0,549928 & 1,833333 & 5 \\
\hline \multicolumn{6}{|l|}{ Persoonlijkheidskenmerken } \\
\hline Neuroticisme & 723 & 3,043338 & 0,916973 & 1 & 5 \\
\hline Extraversie & 723 & 3,596819 & 0,838672 & 1 & 5 \\
\hline Openheid & 723 & 3,52651 & 0,843035 & 1 & 5 \\
\hline Inschikkelijkheid & 723 & 3,913324 & 0,685235 & 1,666667 & 5 \\
\hline Zorgvuldigheid & 723 & 3,572614 & 0,62181 & 1,666667 & 5 \\
\hline Zelf-effectiviteit & 565 & 3,809027 & 0,440993 & 2,3 & 5 \\
\hline Risicopreferentie & 719 & 7,456189 & 1,914746 & 2 & 11 \\
\hline Uitkomstmaten & & & & & \\
\hline
\end{tabular}


TABEL A2.1 Descriptives belangrijkste variabelen nulmeting 1

\begin{tabular}{|l|c|c|c|c|c|}
\hline & N & mean & sd & min & max \\
\hline Leiderschap & 722 & 3,806688 & 0,563521 & 2 & 5 \\
\hline Politieke betrokkenheid & 711 & 1,431894 & 0,599027 & 0,076923 & 2 \\
\hline Politieke betrokkenheid internationaal & 366 & 0,503415 & 0,273371 & 0 & 1 \\
\hline Gestemd in landelijke verkiezingen & 718 & 1,956825 & 0,912994 & 1 & 3 \\
\hline Creativiteit subjectieve schaal & 558 & 3,271505 & 0,499258 & 1,4 & 4,8 \\
\hline Kritisch denken subjectieve schaal & 720 & 3,937014 & 1,082139 & 1 & 7 \\
\hline Alternate uses test & & & & & \\
\hline AUT fluency score & 720 & 12,45 & 5,102319 & 0 & 31 \\
\hline AUT flexibiliteit score & 720 & 12,33194 & 4,596314 & 0 & 34 \\
\hline AUT doorzettings score & 720 & 5,403333 & 1,829321 & 0 & 10,1 \\
\hline Watson-Glaser's test & & & & & 4 \\
\hline WG kritisch denken totaal & 672 & 27,33185 & 5,685367 & 9 & 40 \\
\hline WG kritisch denken percentiel & 672 & 38,63542 & 28,46159 & 1 & 99 \\
\hline WG kritisch denken stanine & 672 & 4,174107 & 1,94585 & 1 & 9 \\
\hline Stage & & & & & 1 \\
\hline In Nederland & 559 & 0,203936 & 0,403283 & 0 & 1 \\
\hline In het buitenland & 559 & 0,116279 & 0,320846 & 0 & 10 \\
\hline Gemiddeld cijfer jaar 1 & 271 & 7,46679 & 0,824668 & 3 & 1 \\
\hline
\end{tabular}

TABEL A2.2 Descriptives belangrijkste variabelen nulmeting 2

\begin{tabular}{|l|l|l|l|l|l|}
\hline & N & mean & sd & min & max \\
\hline Instelling & & & & \\
\hline Maastricht Universiteit & 479 & 0,425887 & 0,494994 & 0 & 1 \\
\hline Hanze hogeschool & 479 & 0,033403 & 0,179874 & 0 & 1 \\
\hline Universiteit Twente & 479 & 0,254697 & 0,436146 & 0 & 1 \\
\hline Radboud Universiteit & 479 & 0,125261 & 0,331361 & 0 & 1 \\
\hline HAN hogeschool & 479 & 0,160752 & 0,367686 & 0 & 1 \\
\hline Deelname aan excellentieprogramma & 479 & 1,505219 & 0,500495 & 1 & 2 \\
\hline Kwam in aanmerking excellentieprogramma & 235 & 2,106383 & 0,817387 & 1 & 3 \\
\hline Examencijfer middelbare school & 473 & 4,843552 & 1,79596 & 1 & 9 \\
\hline Migratieachtergrond & & & & & 1 \\
\hline Geen ouders uit Nederland & 464 & 0,547414 & 0,498284 & 0 & 1 \\
\hline Tenminste één ouder uit Nederland & 464 & 0,452586 & 0,498284 & 0 & 1 \\
\hline Inkomen ouders & & & & & 1 \\
\hline Beneden modaal & 421 & 0,102138 & 0,30319 & 0 & 1 \\
\hline Modaal & 421 & 0,330166 & 0,470832 & 0 & 1 \\
\hline Boven modaal & 421 & 0,567696 & 0,495985 & 0 & 1 \\
\hline Hoogste opleidingsniveau ouders & & & & \\
\hline Basisonderwijs & 466 & 0,008584 & 0,092349 & 0 & 1 \\
\hline LBO, VMBO, MAV0 & 466 & 0,040773 & 0,197975 & 0 & 1 \\
\hline HAV0, Vwo & 466 & 0,05794 & 0,233881 & 0 & 1 \\
\hline MBO & 466 & 0,11588 & 0,320425 & 0 & 1 \\
\hline HBO & 466 & 0,193133 & 0,395181 & 0 & 1 \\
\hline
\end{tabular}


TABEL A2.2 Descriptives belangrijkste variabelen nulmeting 2

\begin{tabular}{|c|c|c|c|c|c|}
\hline & $\mathrm{N}$ & mean & sd & $\min$ & $\max$ \\
\hline WO & 466 & 0,583691 & 0,493476 & 0 & 1 \\
\hline \multicolumn{6}{|l|}{ Gesproken taal thuis } \\
\hline Niet Nederlands sprekend & 473 & 0,58351 & 0,493499 & 0 & 1 \\
\hline Nederlands sprekend & 473 & 0,41649 & 0,493499 & 0 & 1 \\
\hline \multicolumn{6}{|l|}{ Motivatiekenmerken } \\
\hline Intrinsieke motivatie & 474 & 3,932489 & 0,584037 & 2,25 & 5 \\
\hline Extrinsieke motivatie & 474 & 3,517405 & 0,807004 & 1 & 5 \\
\hline Consistentie van interesse & 474 & 3,06294 & 0,74415 & 1 & 4,833333 \\
\hline Doorzettingsvermogen & 474 & 3,819972 & 0,567964 & 1,666667 & 5 \\
\hline \multicolumn{6}{|l|}{ Persoonlijkheidskenmerken } \\
\hline Neuroticisme & 474 & 2,940928 & 0,895938 & 1 & 5 \\
\hline Extraversie & 474 & 3,545007 & 0,846979 & 1,333333 & 5 \\
\hline Openheid & 474 & 3,52602 & 0,81327 & 1 & 5 \\
\hline Inschikkelijkheid & 474 & 3,824191 & 0,728968 & 1,333333 & 5 \\
\hline Zorgvuldigheid & 474 & 3,695499 & 0,656986 & 1,666667 & 5 \\
\hline Zelf-effectiviteit & 474 & 3,827004 & 0,466679 & 2,1 & 5 \\
\hline Risicopreferentie & 474 & 7,464135 & 1,850599 & 2 & 11 \\
\hline \multicolumn{6}{|l|}{ Uitkomstmaten } \\
\hline Leiderschap & 474 & 3,876733 & 0,552311 & 2 & 5 \\
\hline Politieke betrokkenheid & 473 & 1,694747 & 0,203659 & 1 & 2 \\
\hline Politieke betrokkenheid internationaal & 473 & 0,446353 & 0,273273 & 0 & 1 \\
\hline Gestemd in landelijke verkiezingen & 473 & 1,471459 & 0,783658 & 1 & 3 \\
\hline Creativiteit subjectieve schaal & 473 & 3,321353 & 0,490923 & 1,1 & 4,8 \\
\hline Kritisch denken subjectieve schaal & 474 & 3,596624 & 0,720926 & 1,2 & 5 \\
\hline \multicolumn{6}{|l|}{ Alternate uses test } \\
\hline AUT fluency score & 479 & 13,73069 & 5,603021 & 0 & 32 \\
\hline AUT flexibiliteit score & 479 & 11,12735 & 4,274384 & 0 & 25 \\
\hline AUT doorzettings score & 479 & 6,764092 & 2,136445 & 0 & 14,7 \\
\hline \multicolumn{6}{|l|}{ Watson-Glasers test } \\
\hline WG kritisch denken totaal & 479 & 27,3382 & 5,414843 & 12 & 39 \\
\hline WG kritisch denken percentiel & 479 & 37,2881 & 27,89416 & 1 & 99 \\
\hline WG kritisch denken stanine & 479 & 4,075157 & 1,894329 & 1 & 9 \\
\hline \multicolumn{6}{|l|}{ Stage } \\
\hline Stage gelopen in Nederland & 473 & 0,15222 & 0,359614 & 0 & 1 \\
\hline Stage gelopen in het buitenland & 473 & 0,116279 & 0,320899 & 0 & 1 \\
\hline Gemiddeld cijfer jaar 1 & 240 & 7,538333 & 0,852678 & 3,6 & 9,8 \\
\hline
\end{tabular}


TABEL A2.3 Descriptives belangrijkste variabelen eindmeting 1

\begin{tabular}{|c|c|c|c|c|c|}
\hline & $\mathrm{N}$ & mean & $s d$ & $\min$ & $\max$ \\
\hline \multicolumn{6}{|l|}{ Instelling } \\
\hline Universiteit Maastricht & 302 & 0,350993 & 0,478073 & 0 & 1 \\
\hline Hanze hogeschool & 302 & 0,059603 & 0,237142 & 0 & 1 \\
\hline Universiteit Twente & 302 & 0,248344 & 0,43277 & 0 & 1 \\
\hline Radboud Universiteit & 302 & 0,152318 & 0,359925 & 0 & 1 \\
\hline HAN hogeschool & 302 & 0,188742 & 0,391953 & 0 & 1 \\
\hline Deelname excellentieprogramma & 302 & 1,34106 & 0,474852 & 1 & 2 \\
\hline \multicolumn{6}{|l|}{ Motivatiekenmerken } \\
\hline Intrinsieke motivatie & 271 & 3,726015 & 0,604287 & 2 & 5 \\
\hline Extrinsieke motivatie & 271 & 3,160517 & 0,846327 & 1 & 5 \\
\hline Consistentie van interesse & 271 & 3,042435 & 0,72616 & 1,166667 & 5 \\
\hline Doorzettingsvermogen & 271 & 3,881919 & 0,539392 & 1,833333 & 5 \\
\hline \multicolumn{6}{|l|}{ Persoonlijkheidskenmerken } \\
\hline Neuroticisme & 271 & 2,95449 & 0,966932 & 1 & 5 \\
\hline Extraversie & 271 & 3,568266 & 0,846776 & 1 & 5 \\
\hline Openheid & 271 & 3,521525 & 0,818163 & 1,333333 & 5 \\
\hline Inschikkelijkheid & 271 & 3,913899 & 0,687908 & 1,666667 & 5 \\
\hline Zorgvuldigheid & 271 & 3,696187 & 0,638244 & 2 & 5 \\
\hline Zelf-effectiviteit & 271 & 3,856827 & 0,433867 & 2,3 & 4,9 \\
\hline Risicopreferentie & 271 & 7,210332 & 1,959791 & 2 & 11 \\
\hline \multicolumn{6}{|l|}{ Uitkomstmaten } \\
\hline Leiderschap & 271 & 3,928308 & 0,513885 & 2,285714 & 5 \\
\hline Politieke betrokkenheid & 271 & 0,388838 & 0,264474 & 0 & 1 \\
\hline Creativiteit subjectieve schaal & 271 & 3,28524 & 0,536936 & 1,4 & 4,7 \\
\hline Kritisch denken subjectieve schaal & 271 & 3,566052 & 0,618025 & 2 & 4,8 \\
\hline \multicolumn{6}{|l|}{ Alternate uses test } \\
\hline AUT fluency score & 278 & 21,02158 & 7,543345 & 0 & 45 \\
\hline AUT flexibiliteit score & 278 & 15,82734 & 5,021151 & 0 & 31 \\
\hline AUT doorzettings score & 278 & 7,443166 & 1,580136 & 0 & 13,6 \\
\hline \multicolumn{6}{|l|}{ Watson-Glasers test } \\
\hline WG kritisch denken totaal & 270 & 27,7037 & 4,566036 & 5 & 38 \\
\hline WG kritisch denken percentiel & 270 & 56,51481 & 26,34186 & 1 & 99 \\
\hline WG kritisch denken stanine & 270 & 5,414815 & 1,747585 & 1 & 9 \\
\hline Gemiddeld cijfer jaar 2 & 256 & 7,410938 & 0,752745 & 4 & 9,1 \\
\hline Gemiddeld cijfer jaar 3 & 148 & 7,512838 & 0,773478 & 3,6 & 9,3 \\
\hline
\end{tabular}


TABEL A2.4 Descriptives belangrijkste variabelen eindmeting 2

\begin{tabular}{|c|c|c|c|c|c|}
\hline & $\mathrm{N}$ & mean & $s d$ & $\min$ & $\max$ \\
\hline \multicolumn{6}{|l|}{ Instelling } \\
\hline Maastricht Universiteit & 299 & 0,408027 & 0,492292 & 0 & 1 \\
\hline Hanze hogeschool & 299 & 0,020067 & 0,140464 & 0 & 1 \\
\hline Universiteit Twente & 299 & 0,183946 & 0,38809 & 0 & 1 \\
\hline Radboud Universiteit & 299 & 0,130435 & 0,337346 & 0 & 1 \\
\hline HAN hogeschool & 299 & 0,130435 & 0,337346 & 0 & 1 \\
\hline UCM & 299 & 0,12709 & 0,333632 & 0 & 1 \\
\hline Deelname excellentieprogramma & 299 & 1,458194 & 0,499084 & 1 & 2 \\
\hline \multicolumn{6}{|l|}{ Motivatiekenmerken } \\
\hline Intrinsieke motivatie & 271 & 3,774908 & 0,65233 & 1,75 & 5 \\
\hline Extrinsieke motivatie & 271 & 3,293358 & 0,893242 & 1 & 5 \\
\hline Consistentie van interesse & 271 & 3,071341 & 0,720536 & 1 & 4,833333 \\
\hline Doorzettingsvermogen & 271 & 3,849938 & 0,595621 & 2,166667 & 5 \\
\hline \multicolumn{6}{|l|}{ Persoonlijkheidskenmerken } \\
\hline Neuroticisme & 271 & 2,96187 & 0,903002 & 1 & 5 \\
\hline Extraversie & 271 & 3,526445 & 0,935809 & 1 & 5 \\
\hline Openheid & 271 & 3,628536 & 0,770723 & 1,666667 & 5 \\
\hline Inschikkelijkheid & 271 & 3,843788 & 0,706083 & 1,333333 & 5 \\
\hline Zorgvuldigheid & 271 & 3,697417 & 0,673635 & 1,333333 & 5 \\
\hline Zelf-effectiviteit & 271 & 3,870849 & 0,447378 & 2,4 & 4,9 \\
\hline Risicopreferentie & 271 & 7,343173 & 1,890605 & 1 & 11 \\
\hline \multicolumn{6}{|l|}{ Uitkomstmaten } \\
\hline Leiderschap & 272 & 3,935924 & 0,547694 & 1,857143 & 5 \\
\hline Politieke betrokkenheid & 271 & 0,52214 & 0,275494 & 0 & 1 \\
\hline Creativiteit subjectieve schaal & 271 & 3,321033 & 0,539925 & 1,5 & 4,7 \\
\hline Kritisch denken subjectieve schaal & 272 & 3,688971 & 0,663122 & 1 & 5 \\
\hline \multicolumn{6}{|l|}{ Alternate uses test } \\
\hline AUT fluency score & 281 & 15,72954 & 6,114224 & 0 & 33 \\
\hline AUT flexibiliteit score & 281 & 8,886121 & 4,058657 & 0 & 24 \\
\hline AUT doorzettings score & 281 & 8,451601 & 3,323543 & 0 & 17,1 \\
\hline \multicolumn{6}{|l|}{ Watson-Glasers test } \\
\hline WG kritisch denken totaal & 281 & 27,42349 & 4,799034 & 12 & 39 \\
\hline WG kritisch denken percentiel & 281 & 53,75089 & 27,99391 & 1 & 99 \\
\hline WG kritisch denken stanine & 281 & 5,231317 & 1,872703 & 1 & 9 \\
\hline Gemiddeld cijfer jaar 2 & 221 & 7,457466 & 0,877755 & 0 & 9,3 \\
\hline
\end{tabular}




\section{Bijlage 3: Beschrijvende statistieken studentenadministratie}

TABEL A3 Descriptives belangrijkste variabelen studentenadministratiedata

\begin{tabular}{|l|c|c|c|c|c|}
\hline & N & mean & sd & min & $\max$ \\
\hline Honours studenten & 412 & 0,31068 & 0,463334 & 0 & 1 \\
\hline Cijfer voor bachelor scriptie & 245 & 78,18367 & 8,400023 & 50 & 95 \\
\hline Gemiddeld cijfer bachelor & 412 & 74,73855 & 9,899629 & 35 & 92,6 \\
\hline
\end{tabular}

\section{Bijlage 4: Beschrijvende statistieken selecteursoordeel en afronding excellentieprogramma's}

TABEL A4 Descriptives selecteursoordeel en afronding honoursprogramma

\begin{tabular}{|c|c|c|c|c|c|}
\hline & $\mathrm{N}$ & mean & $s d$ & $\min$ & $\max$ \\
\hline \multicolumn{6}{|l|}{ Selecteursoordeel } \\
\hline Stellig afwijzen & 485 & 0,072165 & 0,259028 & 0 & 1 \\
\hline Afwijzen, met twijfel & 485 & 0,051546 & 0,221338 & 0 & 1 \\
\hline Aannemen, met twijfel & 485 & 0,210309 & 0,407949 & 0 & 1 \\
\hline Stellig aannemen & 485 & 0,665979 & 0,472134 & 0 & 1 \\
\hline \multicolumn{6}{|l|}{ Afronding honoursprogramma } \\
\hline Met succes afgerond & 478 & 0,585774 & 0,493104 & 0 & 1 \\
\hline Tot einde gevolgd, maar niet succesvol afgesloten & 478 & 0,016736 & 0,128416 & 0 & 1 \\
\hline Voortijdig uitgevallen & 478 & 0,397490 & 0,489892 & 0 & 1 \\
\hline
\end{tabular}

\section{Bijlage 5: Beschrijvende statistieken vignetten onderzoek}

TABEL A5 Descriptives van belangrijkste variabelen voor het vignetten onderzoek

\begin{tabular}{|l|c|c|c|c|c|c|}
\hline & N & mean & sd & min & max \\
\hline Bijbaan: studie gerelateerd & 2250 & 0,328444 & 0,469752 & 0 & 1 \\
\hline Bijbaan: niet studie gerelateerd & 2250 & 0,340444 & 0,473964 & 0 & 1 \\
\hline Bijbaan: geen ervaring & 2250 & 0,331111 & 0,470718 & 0 & 1 \\
\hline Buitenland ervaring: jaar reizen & 2250 & 0,325333 & 0,468603 & 0 & 1 \\
\hline Buitenland ervaring: studie/stage & 2250 & 0,346667 & 0,476014 & 0 & 1 \\
\hline Buitenland ervaring: geen ervaring & 2250 & 0,328 & 0,469589 & 0 & 1 \\
\hline Gemiddeld cijfer: onder gemiddelde & 2250 & 0,253333 & 0,435017 & 0 & 1 \\
\hline Gemiddeld cijfer: gemiddeld & 2250 & 0,253778 & 0,435269 & 0 & 1 \\
\hline Gemiddeld cijfer: boven gemiddeld & 2250 & 0,247111 & 0,431428 & 0 & 1 \\
\hline Gemiddeld cijfer: beste 10\% & 2250 & 0,245778 & 0,430643 & 0 & 1 \\
\hline Vrijwilligerswerk & 2250 & 0,507111 & 0,500061 & 0 & 1 \\
\hline Geen vrijwilligerswerk & 2250 & 0,492889 & 0,500061 & 0 & 1 \\
\hline Keuze voor een student & 2250 & 0,289333 & 0,453554 & 0 & 1 \\
\hline
\end{tabular}




\section{Bijlage 6: De procedures en criteria voor selectie in het kort}

De selectieprocedures en -criteria van de excellentieprogramma's die hebben deelgenomen aan de metingen onder studenten worden in deze bijlage stuk voor stuk kort beschreven, aan de hand van de volgende aspecten: werving, selectieprocedure, selectiecriteria, omvang interesse en deelname aan het programma.

\section{Radboud Universiteit: Disciplinair honoursprogramma Pedagogische Wetenschappen en Onderwijskunde / Social Sciences}

Het programma vindt plaats in jaar 2 en 3 van de bacheloropleiding en omvat totaal 30 ec. In 2016/17 bestond er een apart honoursprogramma voor studenten Pedagogische Wetenschappen en Onderwijskunde. In 2017/18 is een aantal programma's van de faculteit Sociale Wetenschappen van de Radboud Universiteit samengevoegd tot het honoursprogramma Social Sciences, met deelnemers uit de opleidingen Pedagogische Wetenschappen en Onderwijskunde, Communicatiewetenschap, Sociologie en Culturele Antropologie en Ontwikkelingsstudies.

\section{Werving}

De $25 \%$ beste studenten ontvangen een persoonlijke uitnodigingsbrief ondertekend door de rector, mentoren worden gevraagd om namen van potentieel geschikte studenten aan de coördinator door te geven en de jaarlijks voorlichtingsbijeenkomst wordt via blackboard aangekondigd. Bij lage opkomst bij de voorlichting is door de coördinator ook tijdens een aantal tweedejaars colleges een korte toelichting op het honoursprogramma gegeven. Bij de overgang naar het honoursprogramma Social Sciences heeft de nieuwe programmaregisseur voorlichting gegeven aan de docenten van het eerste bachelorjaar over het nieuwe programma en zijn zij gevraagd actief potentiele honoursstudenten te scouten.

\section{Selectieprocedure}

Studenten sturen een motivatiebrief in, met cv en cijferlijst (voor de studenten 2016/17 van het vwo, sinds 2017/18 van bachelorjaar 1). Vanwege het beperkte aantal aanmeldingen worden in de schriftelijke ronde weinig studenten afgewezen. Criteria om eventueel wel af te wijzen in deze fase zijn: inhoudelijke slechte brief of brief waar weinig aandacht aan is besteed (met fouten) of ontbrekende onderbouwing voor het niet behalen van de propedeuse.

Vervolgens worden studenten uitgenodigd op gesprek. Gesprekken zijn individueel en werden gehouden door wisselende duo's van docenten. Dit laatste uit pragmatische overwegingen van werkdruk en om ervoor te zorgen dat de interviewers niet in een vast denkpatroon geraken. In 2017/18 zijn de gesprekken gevoerd door de programmavoorzitter en de programmaregisseur. 
Studenten krijgen vooraf de opdracht om hun empirisch project uit het eerste jaar te pitchen. Dat wordt gebruikt als een graadmeter voor inhoudelijkheid en enthousiasme. Verder wordt een aantal vaste vragen gesteld naar het laatst gelezen boek (inhoudelijkheid), welke rol speel je in een groep en waarom wil je honoursprogramma doen (zelfreflectie). Gesprekken duren 15 minuten en na afloop bespreken de interviewers na. Het gesprek verloopt dus volgens een vast format. Sommige selecteurs zijn al vanaf het begin van het programma in 2009 erbij betrokken. De criteria liggen niet vast en zijn meer impliciet dan expliciet. Wel is er een document waarin een soort ideaalbeeld van een scientist practitioner met honours staat beschreven. Studenten hoeven niet alle genoemde eigenschapen te voldoen, maar naar studenten wordt wel de verwachting uitgesproken dat zij de ambitie hebben om meer op dit ideaalbeeld te gaan lijken. Het traject wordt al gezien als een vorm van preselectie; studenten moeten in de aanmeldfase moeten al moeite, door het schrijven van de brief en het voorbereiden van de opdracht. In jaren met grotere aantallen aanmelders zijn wel studenten afgewezen. Er zijn in principe 20 plaatsen beschikbaar maar deze hoeven niet gevuld te worden.

\section{Selectiecriteria}

Het eerste criterium is in principe dat de propedeuse in één jaar behaald moet zijn met een 7 gemiddeld. Hier kan alleen beargumenteerd van worden afgeweken, maar dit is in de praktijk nog niet voorgevallen. Verder is motivatie belangrijk en onderzoeksinteresse. De programmaregisseur gaf in 2016/17 aan dat de focus aan het verschuiven was van puur academisch talentvolle studenten (goede studieresultaten) naar meer aandacht voor motivatie en ambitie. Soms is er sprake van onderpresteren omdat studenten te weinig geprikkeld worden of omdat ze op gang moeten komen op de universiteit. Het past ook beter bij de richting van het programma om meer naar andere kwaliteiten van studenten te kijken.

Volgens de programmaregisseurs onderscheiden honoursstudenten zich onder meer door: enthousiasme, individuele zelfstandigheid, kritisch denken, creativiteit in de manier waarop ze met de vragen van de commissie omgaan en uniciteit. Deze criteria zijn echter niet voorwaardelijk. Het doel is om een goede groepssamenstelling te krijgen met een mix van verschillende mensen. Twijfelgevallen zijn studenten die minder enthousiast zijn, die voor het honourscertificaat op hun cv gaan, weinig kritisch zijn of minder goede studieprestaties hebben. De meeste honoursstudenten vallen binnen de groep van $25 \%$ beste studenten.

Toelating is altijd onder voorwaarde. Na het eerste semester wordt de deelname aan het honoursprogramma geëvalueerd. Studenten kunnen dan alsnog weggestuurd worden als de resultaten van de reguliere opleiding eronder lijden. Studenten gingen in het programma tot en met 2016/17 voor een korte periode naar het buitenland, naar buitenlandse contacten van de opleiding. Als de opleiding de student geen goede afgevaardigde achtte, kon dit in theorie aanleiding zijn om de student uit te sluiten van verdere deelname aan het honoursprogramma. In het nieuwe programma is er geen verplichte buitenlandperiode meer. 


\section{Omvang interesse en deelname}

De $25 \%$ bestpresterende studenten worden aangeschreven. Dit aantal wisselt en was in 2016 lager dan 50 door een lagere instroom. Er zijn in 2016/17 geen studenten afgewezen; één student trok zich voor het gesprek terug; twaalf studenten zijn gestart. In 2017/18 is één student afgewezen en zijn zeven studenten gestart.

\section{Radboud Universiteit: Disciplinair honoursprogramma Psychologie}

Het programma vindt plaats in jaar 2 en 3 van de bacheloropleiding en omvat totaal 30 ec.

Het programma heeft twee varianten: het traject gezondheidszorgpsychologie en het algemene psychologie traject. Het eerste traject vindt voor een substantieel deel bij een gz-instelling plaats.

\section{Werving}

Begeleiders van het vak academische vaardigheden houden voortgangsgesprekken en bespreken het honoursprogramma met studenten. Naast deze directe benadering ontvangen alle tweedejaars een e-mail en de $25 \%$ beste studenten met minimaal een 7,5 gemiddeld een aanmoedigingsbrief van de rector. Vervolgens is er een voorlichtingsbijeenkomst.

\section{Selectieprocedure}

Studenten geven hun tot dan toe behaalde studieresultaten op en schrijven een sollicitatiebrief waarin ze het gz-traject als voorkeur mogen opgeven en het algemene traject als tweede voorkeur in een gecombineerde brief (andersom komt niet voor). In de schriftelijke ronde vindt alleen afwijzing plaats op formele gronden als bijvoorbeeld een student hele slechte resultaten heeft en dit niet onderbouwt.

De eerste gespreksronde dient ter selectie van de deelnemers voor het gz-traject. Hiervoor worden 15 studenten uitgenodigd. Dit jaar was daar geen selectie voor nodig, de jaren ervoor wel. In de schriftelijke sollicitatie wordt gekeken naar studieresultaten (propedeuse gehaald) en onderbouwde motivatie in de brief waaruit beleidsmatige ambitie blijkt ('het is geen algoritme, we vertrouwen op het inzicht van de commissie'). De selectiecommissie bestaat uit drie personen die alle drie bij alle gesprekken aanwezig zijn. Een gesprek duurt 20 minuten en heeft geen vast format. Afgewezen studenten gaan mee in de procedure voor het algemene traject. Daarvoor worden eveneens gesprekken gehouden, steeds met twee personen waarvan één altijd de honourscoördinator is. Via de mail in een Excel bestand wordt feedback gegeven en geldt de driedeling: toelaten, afwijzen, twijfel. De commissie is het meestal behoorlijk eens. Zo niet, krijgt de student het voordeel van de twijfel.

\section{Selectiecriteria}

Het gesprek voor de gz-variant wordt gebruikt om te kijken of de student de tijdsbesteding juist inschat en het erbij kan hebben, om te bezien of er correspondentie is tussen 
wat de student wil en verwacht en wat ze gaan krijgen, of de student juiste persoonlijkheid en communicatieve vaardigheden heeft om in een gz-instelling te functioneren, beleidsmatige interesse heeft, niet te jong in zijn/haar ontwikkeling meer is.

In het gesprek voor de algemene variant wordt gelet op: inhoudelijke interesse, onderzoeksinteresse, tijdsbelasting van het honoursprogramma (past het nog naast het reguliere programma) en zelfstandigheid (het honoursprogramma is minder voorgestructureerd dan het reguliere programma) en studieresultaten (zijn behoorlijk goede voorspeller, bij minder goede resultaten wordt gekeken of er wel positieve ontwikkeling zichtbaar is). De commissie is alert op zelfpresentatie en vraagt kritisch door. Toch is er wel uitval, meestal vanwege persoonlijke veranderingen of problemen.

\section{Omvang interesse en deelname}

60 studenten hebben een brief gekregen, 50 studenten hebben de voorlichting bezocht en 46 hebben zich aangemeld. Het gezondheidszorgtraject heeft acht plaatsen en meer belangstelling; het algemene traject heeft 30 plaatsen die niet per se gevuld worden.

\section{Hogeschool van Arnhem en Nijmegen: Faculteit Economie en Management Talent Academy (FEMTA)}

Het programma vindt plaats in jaar 3 en 4 van de opleiding en omvat totaal 30 ec. Het programma staat open voor studenten van elf opleidingen van de Faculteit Economie en Management.

\section{Werving}

FEMTA-docenten hebben sleutelposities in de reguliere opleidingen. Zij promoten het excellentieprogramma en werven studenten. Ook de slb'ers en andere docenten dragen studenten aan. Docenten letten op 'eagerness' in de klas, vragen stellen, de kwaliteit van de beroepsproducenten (conceptueel sterk, studenten die verder kijken) en de bereidheid om dingen naast de opleiding te doen.

\section{Selectieprocedure}

Studenten kunnen via de website melden dat ze interesse hebben in het programma (aanmelding met een korte motivatie). De coördinator stuurt een mail terug, met daarin een persoonlijk noot en een uitnodiging voor de vervolgprocedure. Geïnteresseerde studenten kunnen vervolgens solliciteren met een $c v$, cijferlijst en twee aanbevelingen, van een docent en een mentor/slb'er. De coördinator beoordeelt de ingezonden stukken. Vervolgens zijn er gesprekken met steeds twee selecteurs (uit een team van vijf). Het gesprek heeft een inleiding door de gespreksvoerder, kan in principe naar alle kanten uitwaaien en eindigt met feedback naar de student. Na de gesprekken krijgen studenten een mail met onderbouwing waarom ze wel/niet door mogen, met enkele ontwikkelpunten. De selecteurs beschrijven die punten in een mail naar de coördinator en hij maakt op basis daarvan een mail voor de student. Na de gesprekken volgt de groepsopdracht die de studenten thuis moeten voorbereiden. Deze wordt uitge- 
voerd onder begeleiding van twee facilitators van buiten de HAN. Enkele selecteurs zijn aanwezig om te observeren, met name gericht op de studenten waarover twijfel bestaat. Daar wordt gekeken of bijvoorbeeld een muurbloem de wil heeft om te spreken en een student met een grote mond een stapje terug kan doen.

Bij toelating moet elke student individueel toestemming voor uitbreiding van de studielast aan de examencommissie vragen (omdat dit is een potentieel risico voor de studievoortgang van de reguliere opleiding is). Daarbij moet de examencommissie toestemming geven omdat het excellentieprogramma op het diploma wordt vermeld. De examencommissie checkt ook of het excellentieprogramma geen verdubbeling met het reguliere programma oplevert. Voor de onderdelen die meer gericht zijn op Bildung is dat soms lastig.

\section{Selectiecriteria}

Tijdens het gesprek wordt op de volgende aspecten gelet:

- Eerste indruk (hoe komt iemand binnen, is de student voorbereid)

- Authenticiteit

- Motivering van de student, drive

- Hoe komt de student uit zijn woorden, kan de student redeneren, hoe is het vocabulaire?

- Risicobereidheid

Verder wordt bevraagd hoe studenten omgaan met groepswerk (welke rol nemen ze aan en wat doen ze bijvoorbeeld als het misgaat). Vrijwilligerswerk en extracurriculaire activiteiten zeggen iets over de drive, capaciteiten en de bereidwilligheid van studenten. Ook hobby's en sportbeoefening worden bevraagd. Dit kan informatie geven over eigenschappen van de student zoals teamgeest en specifieke interesses. Ook is het belangrijk om in te schatten of deze student niet te veel hooi op de vork neemt. Studievoortgang is daarnaast ook belangrijk. Het blijken veelal studenten met een vwo-vooropleiding te zijn die zich aanmelden voor het excellentieprogramma. Dit is echter geen voorwaarde. Wat betreft de meer subjectieve kenmerken zijn creativiteit, ambitie, doorzettingsvermogen en maatschappelijke betrokkenheid erg belangrijk. Evenzo belangrijk zijn kritisch, analytisch en reflectief denkvermogen.

De selecteurs hebben een professionele basis, maar de insteek wisselt per keer. Ze zijn het altijd wel eens over de boven- en ondergroep, maar daartussen bevinden zich soms lastige twijfelgevallen. Uiteindelijk is er dan vaak sprake van zelfselectie en trekken die studenten vaak zelf de conclusie om niet door te gaan.

De selectiecriteria zijn beschreven in document dat als richtlijn dient voor de individuele gesprekken en benoemt de criteria, naast de eis van voldoende studievoortgang, als volgt: willen, kunnen, durven, samen, dromen en doen, met korte beschrijvingen van competenties en eigenschappen. 
Omvang interesse en deelname

In 2016 hebben 53 studenten deelgenomen aan de selectieprocedure en zijn 47 studenten geselecteerd.

\section{Hogeschool van Arnhem en Nijmegen: Honoursprogramma Faculteit Gezondheid, Gedrag en Maatschappij (GGM)}

Het programma vindt plaats in de tweede helft van jaar 2 en jaar 3 van de opleiding en omvat totaal 22,5 ec. Het programma stond in 2016/17 voor het eerst open voor studenten van alle opleidingen van de faculteit Gezondheid, Gedrag en Maatschappij.

\section{Werving}

Studenten ontvangen via de mail een uitnodiging voor de twee voorlichtingsbijeenkomsten die worden georganiseerd. Ook studieloopbaanbegeleiders ontvangen een uitnodiging en aan hen wordt gevraagd om potentieel geschikte en geïnteresseerde studenten individueel aan te spreken. Jaarlijks bezoeken 30 tot 40 studenten een bijeenkomst. Studenten ontvangen nog een mail met informatie over de aanmeldtermijn en een reminder kort voor de sluitingsdatum. Geïnteresseerde studenten wordt geadviseerd om het jaarlijkse symposium van het honoursprogramma te bezoeken om zich verder te oriënteren. Als bepaalde opleidingen achterblijven bij de aanmeldingen ontvangen studenten van deze opleiding nog een extra mailbericht.

\section{Selectieprocedure}

Studenten schrijven een motivatiebrief en cv, met cijferlijst en twee aanbevelingen van een docent en een studieloopbaanbegeleider. Vervolgens kunnen studenten op een rooster intekenen voor een intakegesprek. Een deel van de gesprekken wordt gevoerd door de coördinator van het programma en een deel door een alumnus van het honoursprogramma. De gesprekken worden gevoerd volgens een vast gespreksformat dat de volgende onderdelen omvat: achtergrond (opleiding, competenties, talenten), motivatie (intrinsiek, extrinsiek, motivatie om te brengen/terug te geven), capaciteiten, gelegenheid (hobby's, sport, werk, sociaal), wederzijdse verwachtingen en vertrouwen in eigen studiesucces. Deze onderdelen worden met plussen en minnen gescoord (++ tot --).

\section{Selectiecriteria}

Uit de brief en het cv moet blijken dat studenten zich hebben verdiept in het programma en hun interesse in deelname kunnen motiveren. In de gesprekken wordt gelet op extracurriculaire activiteiten die een indicatie zijn van (maatschappelijke) betrokkenheid van studenten, de wil om te ontwikkelen en open staan voor feedback. Studenten moeten verbindingen kunnen leggen, een visie op zorg hebben en hebben nagedacht over wat het honoursprogramma hen brengt en wat zij naar het programma brengen. De coördinator wil studenten die kritisch zijn, coherent, langetermijninzicht hebben, volwassenheid tonen en het programma inzetten om een betere professional te worden. 
De voorkeur gaat uit naar zogenaamde 'gifted learners' en 'creative thinkers' en minder naar 'high achievers'. Niettemin zijn alle drie deze typen studenten wel gewenst in de groep vanwege de groepsdynamiek en omdat ze van elkaar kunnen leren. Uitgangspunt is dat studenten die zich hebben aangemeld, met aanbevelingen en brief, al moeite hebben gedaan en over een zekere mate van motivatie beschikken.

De enige expliciet vastgelegde normen betreffen de studieresultaten: de student heeft gemiddeld minimaal een 7 en de propedeuse behaald. Beide normen zijn richtlijnen en worden niet rigide gehanteerd, mits er goede redenen zijn om af te wijken. De uiteindelijke beslissing tot toelating of afwijzing ligt bij de coördinator.

\section{Omvang interesse en deelname}

Er is de afgelopen jaren feitelijk weinig geselecteerd omdat er vaak geen of weinig meer aanmeldingen waren dan de 25 plaatsen die jaarlijks beschikbaar zijn. In voorjaar 2017 zijn 29 van de 31 aangemelde studenten aangenomen.

\section{Universiteit Maastricht: Honoursprogramma School of Business and Economics (SBE)}

Het programma vindt plaats in jaar 2 en 3 en omvat 30 extra ec. Het programma staat open voor studenten van alle opleidingen van SBE: Econometrics and Operation research, Economics and Business Economics, Fiscal Economics en International Business.

\section{Werving}

Studenten met een 'grade point average' (GPA) van minimaal 8 worden uitgenodigd voor een voorlichtingsbijeenkomst. Informatie over het programma staat op de universitaire website.

\section{Selectieprocedure}

Studenten kunnen zich aanmelden met een motivatiebrief en een cv. In de motivatiebrief gaat het om het aantonen van maatschappelijke betrokkenheid, ideeën over het invullen van de credits, motivatie, leergierigheid en ideeën voor een onderzoeksvraag.

\section{Selectiecriteria}

Alle aanmeldingen worden door twee selecteurs (de coördinator van het programma en de bachelordirecteur) gescoord op de volgende onderdelen: motivatiebrief, cv, uitvoerbaarheid van plannen, overall indruk. De scores op deze vier onderdelen worden gemiddeld. Deze score wordt samen met het GPA gemiddeld en op basis hiervan worden de aanmeldingen gerankt. Het GPA meet de academische prestaties, de andere onderdelen de maatschappelijke betrokkenheid van de student.

In de brief wordt gelet op engagement en in hoeverre de student actief is buiten de opleiding. Dit wordt als graadmeter gebruikt om in te schatten of de studenten wellicht meer cum laude jagers zijn of dat ze echt leergierig zijn en een idee hebben wat ze met 
het programma willen gaan doen. Andere meer subjectieve criteria zijn: academische vaardigheden, creativiteit, ambitie en maatschappelijke betrokkenheid. Academische en communicatieve vaardigheden worden in het probleemgestuurd onderwijs getoetst (bijv. in het 'participation grade') en zijn daarmee in het GPA verrekend.

\section{Omvang interesse en deelname}

In 2016 zijn 30 studenten op basis van hun GPA uitgenodigd voor deelname. In totaal 27 studenten hebben zich aangemeld en zij zijn allen aangenomen.

\section{Universiteit Maastricht: Law College}

Het honoursprogramma loopt in jaar 1, 2 en 3 en omvat 36 ec. Het is toegankelijk voor alle opleidingen van de faculteit: Nederlands Recht, Fiscaal Recht en European Law School.

\section{Werving}

De werving en selectie voor het Law College is afwijkend van de andere honoursprogramma's omdat studenten vanaf het eerste jaar deelnemen en werving en selectie dus voorafgaand aan de start van de reguliere bachelor moet plaatsvinden. Studenten die zich aanmelden voor de reguliere bachelor Rechtsgeleerdheid moeten de studiekeuzecheck invullen. Dit is een uitgebreid formulier met vragen naar de examencijfers voor Engels, Wiskunde en Geschiedenis, motivatie voor de opleiding, welke vakken ze waarom interessant vinden (om te checken in hoeverre ze zich al hebben verdiept in het programma), internationale ervaring (voor de European Law School), zelfinschatting van studievaardigheden, waarom ze geschikt zijn voor de opleiding en 'global citizenship' (extracurriculaire activiteiten en vrijwilligerswerk). Verder moeten ze een inhoudelijke stelling uitkiezen en hierop reageren en zelf een juridisch probleem identificeren en uitleggen. Binnen elke opleiding is er een team die de studiekeuzecheck beoordeelt en tot een gewogen totaalscore komt. Op basis van deze score krijgen studenten een kleurcode: rood, oranje, groen en groenplus. De studenten met een groenplusscore krijgen een mail met een aanmeldformulier en een uitnodiging om zich aan te melden voor het Law College.

\section{Selectieprocedure}

Studenten kunnen een aanmeldformulier, cv en andere relevante documentatie (zoals profielwerkstuk, certificaten voor deelname aan debatten, model VN etc.) insturen. In het aanmeldformulier wordt gevraagd om zelfreflectie op sterke en zwakke eigenschappen en persoonlijke ontwikkelingsdoelen. De drie leden van het toelatingsbestuur van het honoursprogramma bekijken elk een aantal dossiers. In de regel worden aanmelders vervolgens uitgenodigd voor een van de twee selectiedagen. Afwijzing op basis van dossier gebeurt alleen als er op meerdere punten laag wordt gescoord. Bij een mogelijke afwijzing legt de beoordelaar het dossier eerst voor aan een ander lid van het bestuur. Een 'ja' van één lid is voldoende om de student uit te nodigen. 
Op de selectiedag krijgen de aankomend studenten eerst een kort college met een individuele opdracht en daarna een groepsopdracht met vier studenten en een docentcoach. De coach heeft een scoreformulier dat voor elke student wordt ingevuld. Tijdens de dag halen de coördinator en collega-docent alle studenten tien minuten uit de groep voor een kort interview. Daarnaast is er nog een collega die langs alle groepen loopt, zodat er ook iemand is die alle groepen heeft gezien en onderling kan vergelijken. $\mathrm{Na}$ afloop vult de student zelf nog formulier in met zelfreflectie en peerfeedback.

Na de selectiedag volgt een gezamenlijke bespreking en worden studenten beoordeeld: toelating, afwijzing of 'on hold' tot na tweede selectiedag.

\section{Selectiecriteria}

Selectiecriteria voor de selectiedag zijn niet expliciet vastgelegd en selectie gebeurt veelal op basis van 'gut instinct' gebaseerd op de bijdrage die studenten leveren aan het groepswerk, of ze een goede indruk maken tijdens het interview en of blijkt of ze voorwerk hebben gedaan. De vrij zwaar aangezette selectie maakt dat er meer kwalitatief goede aanmeldingen komen van de European Law school. Daarom wordt bij de Nederlandse studenten wat meer gekeken naar potentie en interesse in zelfontwikkeling. Belangrijke formele kenmerken zijn de studieresultaten en extracurriculaire activiteiten of vrijwilligerswerk. Ambitie en academische en sociale vaardigheden zijn basisvoorwaarden en daarna wordt gekeken 'which boxes they tick'.

$\mathrm{Na}$ een half jaar vindt er een review plaats waarbij soms een student wordt weggestuurd op 'on probation' wordt gezet, meestal omdat ze achteropraken in het reguliere programma.

\section{Omvang interesse en deelname}

In totaal hebben zich 70 tot 80 studenten aangemeld en zijn 40 studenten geselecteerd.

\section{Hanzehogeschool Groningen: Honourstalentprogramma Instituut voor Bedrijfskunde - HRM}

Het programma loopt in jaar 2, 3 en 4, omvat 30 ec, is toegankelijk voor studenten van alle opleidingen van het Instituut voor Bedrijfskunde (IBK) en heeft een opleidingsspecifieke invulling voor Human Resource Management.

\section{Werving}

Het honoursprogramma wordt op intranet aangekondigd, de coördinator gaat de klassen langs en studieloopbaanbegeleiders wordt gevraagd om potentieel geschikte studenten door te geven. De coördinator checkt de studievoortgang en als deze voldoende is, ontvangt de gescoute student een brief met de vraag of hij/zij zich wil aanmelden voor het programma. 


\section{Selectieprocedure}

Aanmelding omvat een cv, motivatie en persoonlijk profiel in vrije vorm. Na aanmelding vindt een check op studievoortgang plaats (voor studenten voor wie dat nog niet was gebeurd). Er is hiervoor geen harde grens geformuleerd; een student mag wel een paar vakken hebben gemist maar niet de helft. De coördinator maakt een spreadsheet met studieresultaten (code groen, oranje of rood) en vragen naar aanleiding van het profiel. In de regel worden geen studenten in deze eerste fase afgewezen en mogen ze allemaal door naar de assessmentmiddag. Tijdens deze middag delen de studenten wie ze zijn, waarom ze dit zoeken, lichten ze hun keuzes toe en bevragen ze de anderen. Dit geeft een indruk van hun interactief leervermogen, zelfreflectie en zichzelf kunnen presenteren. Daarna voeren ze een creatieve groepsopdracht uit, onder begeleiding van de coördinator en een andere docent. Steeds heeft één van beide de lead in de begeleiding en observeert de ander.

\section{Selectiecriteria}

Samen vullen de twee betrokken beoordelaars in collegiaal overleg na afloop de spreadsheet aan met de indrukken van de middag op de volgende kenmerken, met scores goed, voldoende of twijfel:

- Vernieuwingsgericht - Is enthousiast en open in het zoeken naar nieuwe uitwerkingen en gebruik van creativiteit;

- Samenwerkingsgericht - Stelt zich open op in de samenwerking met anderen en neemt initiatief; geeft feedback, stelt vragen;

- Interactief leervermogen - Duidelijke visie op de eigen 'why, what, how'; Stelt vragen aan anderen over hun drijfveren.

Naast de genoemde aspecten zijn ook reflectiviteit en communicatieve vaardigheden belangrijke aspecten. Er zijn geen harde normen voor toelating/afwijzing. Het gaat volgens de coördinator om het evenwicht tussen objectiveren en werkbaar houden. Het gaat om de indruk van de twee betrokken docenten en dat is in deze werkwijze voldoende geformaliseerd. Het assessment wordt gezien als een hulpmiddel voor selectie, zowel voor het honoursprogramma als voor de studenten om te bezien of het programma bij ze past.

\section{Omvang interesse en deelname}

In 2016 waren er 140 tweedejaars HRM. Zij mogen zich in principe allemaal aanmelden. Docenten hebben totaal 24 studenten aangedragen waarvan er na een check op studievoortgang 18 zijn aangeschreven. 14 studenten hebben deelgenomen aan de assessmentmiddag. Drie studenten hebben zich teruggetrokken, één student is afgewezen waardoor uiteindelijk tien studenten zijn gestart. Er staat vooraf geen minimaal of maximaal aantal deelnemers vast, wel was er de wens om het aantal deelnemers wat te laten stijgen en dat is gelukt. 


\section{Hanzehogeschool Groningen: Honourstalentprogramma Instituut voor Bedrijfskunde - Bedrijfskunde MER}

Het programma loopt in jaar 2, 3 en 4, omvat 30 ec, is toegankelijk voor studenten van alle opleidingen van het instituut IBK en heeft een opleidingsspecifieke invulling voor Bedrijfskunde MER.

\section{Werving}

Aan studieloopbaanbegeleiders wordt gevraagd om geschikte kandidaten aan te dragen. Criteria voor initiële geschiktheid zijn: intrinsiek gemotiveerd en bijna propedeuse gehaald. Op de IBK-website wordt een oproep geplaatst om breder te werven. Vervolgens is er een informatiebijeenkomst die open staat voor alle studenten.

\section{Selectieprocedure}

Studenten kunnen zich aanmelden voor het programma met een $\mathrm{cv}$ en een zelfprofiel. De vorm hiervan is vrij, maar studenten moeten hierin aandacht besteden aan hun 'personal why' en motiveren waarom ze aan het honoursprogramma willen meedoen. Ook moeten ze een 'nulmeting competenties' meenemen in hun aanmelding, gebaseerd op een document over het honoursprogramma. Er zijn vier honoursdocenten bij bedrijfskunde en zij lezen alle vier de sollicitaties en vragen waar nodig aanvulling van de student. Een student wordt in dit stadium dus nog niet afgewezen vanwege bijvoorbeeld een onvolledige sollicitatie. Vervolgens worden er gesprekken met tweetallen studenten gepland, steeds met één honoursdocent en een ouderejaars honoursstudent. In het gesprek wordt de motivatie en de nulmeting competenties besproken en wordt gekeken hoe de studenten op elkaar ingaan en wat ze kunnen bijdragen aan de groep. Het gesprek heeft een vrije vorm, er is geen gespreksformat. Het team dat de gesprekken heeft gevoerd bespreekt alle studenten na; eerst worden de zekere toelatingen eruit gehaald en daarna wordt gesproken over de twijfelgevallen. Er wordt overlegd tot er overeenstemming is. Mocht dat niet lukken, dan zou de coördinator de beslissing nemen, maar dit is nog nooit nodig geweest. Opvallend in deze procedure was dat de honoursstudenten de selectiviteit van het programma willen verdedigen terwijl de docenten meer kijken naar potentieel en ontwikkelingsmogelijkheden.

\section{Selectiecriteria}

Studenten moeten op het moment van selectie bijna hun propedeuse hebben behaald. Verder heeft het programma heeft een zogenaamd excellentieprofiel dat bestaat uit de volgende zes competenties: vernieuwingsgerichtheid, intrapreneurship, leiderschap, samenwerkingsgerichtheid, duurzaamheidsgerichtheid en interactief leervermogen. Studenten gebruiken deze zes competenties als uitgangspunt voor de nulmeting die ze in hun zelfprofiel beschrijven en hierop worden ze in het gesprek bevraagd. Er zijn geen harde normen voor deze criteria. In het gesprek wordt gelet op proactiviteit, ondernemendheid/willen uitproberen, willen samenwerken/community willen vormen en een persoonlijk doel met het honoursprogramma hebben. Het programma is van de 
student. Het is veel zelfstandig werk dus het is belangrijk dat studenten gemotiveerd zijn. Daarom is er in de metingsjaren veel aandacht besteed aan de 'personal why'.

\section{Omvang interesse en deelname}

Er waren in 2016 ongeveer 200 studenten in het eerste jaar Bedrijfskunde MER. Vijftien studenten hebben zich aangemeld en er zijn dertien studenten toegelaten.

\section{Universiteit Twente: Honoursprogramma}

Het honoursprogramma duurt anderhalf jaar en loopt tijdens de tweede helft van jaar 1 en heel jaar 2 van de bachelor. Het programma omvat 30 ec en kent vijf varianten (tracks): Science, Design, Processes of Change, Mathematics en Philosophy.

\section{Werving}

Het programma is voor studenten die meer kunnen en willen. De dean van het honoursprogramma is voorzichtig met het gebruik van de tem 'selectie' in het kader van het honoursprogramma want dat lijkt studenten af te schrikken.

Er wordt jaarlijks campusbreed geworven voor het programma met posters en flyers. Honoursstudenten flyeren zelf. Er worden informatiebijeenkomsten in de vorm van lunchsessies georganiseerd. Veel werving en communicatie gebeurt door studenten zelf, via de honours student association. Ook worden directeuren van de opleidingen gevraagd om de beste studenten van de eerste module uit te nodigen voor het programma. Hoe deze selectie precies verloopt en in hoeverre studenten hier gehoor aan geven is echter niet duidelijk. Wel is er volgens de dean sprake van zelfselectie. Studenten weten zelf goed of een goede fit zijn voor het programma.

\section{Selectieprocedure}

Studenten kiezen vooraf een track en sturen een motivatiebrief en studieresultaten in. De coördinator van het programma en een student-assistent (een oud-honoursstudent) bekijken alle brieven. Er vindt geen selectie plaats op basis van de brieven en sinds 2016/17 vindt voor het eerst met alle studenten een gesprek plaats (voorheen alleen met twijfelgevallen). De interviews werden per track gehouden door een docent met een senior honoursstudent. Er was geen vast stramien voor de interviews en deze bleken dan ook heel verschillend te verlopen. De betrokken senior honoursstudenten hebben vervolgens een interview guideline opgesteld voor volgend jaar.

\section{Selectiecriteria}

Het gaat volgende de dean vooral om attitude en motivatie, meer dan om competenties. Studenten moeten willen samenwerken, crossdisciplinair werken, open staan voor andere perspectieven, verder willen kijken dan de eigen discipline (denk ook aan het oversteken van de grens tussen het technische en sociale domein) en 'off the beaten track' willen gaan. De docenten letten in de interviews vooral op academische competenties, de senior honoursstudenten stelden vooral vragen over motivatie, fit en 
beschikbare tijd. Verder werd er ook gesproken over verwachtingen van het honoursprogramma.

In de regelgeving voor het honoursprogramma zijn de volgende criteria opgenomen: De student is:

- talented, motivated and enterprising;

- has great course results and a nominal study progress;

- likes to go off the beaten track, looks beyond the borders of disciplines and looks for ways to ensure that his ideas have an impact on society;

- has the potential to complete the Honours Programme within the set period'

Omvang interesse en deelname

In 2016/17 hebben iets meer dan 60 studenten zich aangemeld, drie tot vier studenten zijn afgewezen en 58 studenten zijn geselecteerd. 
